\title{
The Social Roots of Favara, Sicily: A tool for reigniting a crumbling city centre
}

By Natalia Woldarsky Meneses

A thesis submitted to the Faculty of Graduate and Postdoctoral Affairs in partial fulfillment of the requirements for the degree of

Masters of Architecture

MArch Professional

Carleton University

Ottawa, Ontario 
Library and Archives

Canada

Published Heritage

Branch

395 Wellington Street

Ottawa ON K1A ON4

Canada
Bibliothèque et

Archives Canada

Direction du

Patrimoine de l'édition

395 , rue Wellington

Ottawa ON K1A ON4

Canada
Your file Votre référence

ISBN: 978-0-494-94570-4

Our file Notre référence

ISBN: 978-0-494-94570-4
NOTICE:

The author has granted a nonexclusive license allowing Library and Archives Canada to reproduce, publish, archive, preserve, conserve, communicate to the public by telecommunication or on the Internet, loan, distrbute and sell theses worldwide, for commercial or noncommercial purposes, in microform, paper, electronic and/or any other formats.

The author retains copyright ownership and moral rights in this thesis. Neither the thesis nor substantial extracts from it may be printed or otherwise reproduced without the author's permission.
AVIS:

L'auteur a accordé une licence non exclusive permettant à la Bibliothèque et Archives Canada de reproduire, publier, archiver, sauvegarder, conserver, transmettre au public par télécommunication ou par l'Internet, prêter, distribuer et vendre des thèses partout dans le monde, à des fins commerciales ou autres, sur support microforme, papier, électronique et/ou autres formats.

L'auteur conserve la propriété du droit d'auteur et des droits moraux qui protege cette thèse. $\mathrm{Ni}$ la thèse ni des extraits substantiels de celle-ci ne doivent être imprimés ou autrement reproduits sans son autorisation.
In compliance with the Canadian Privacy Act some supporting forms may have been removed from this thesis.

While these forms may be included in the document page count, their removal does not represent any loss of content from the thesis.
Conformément à la loi canadienne sur la protection de la vie privée, quelques formulaires secondaires ont été enlevés de cette thèse.

Bien que ces formulaires aient inclus dans la pagination, il n'y aura aucun contenu manquant. 


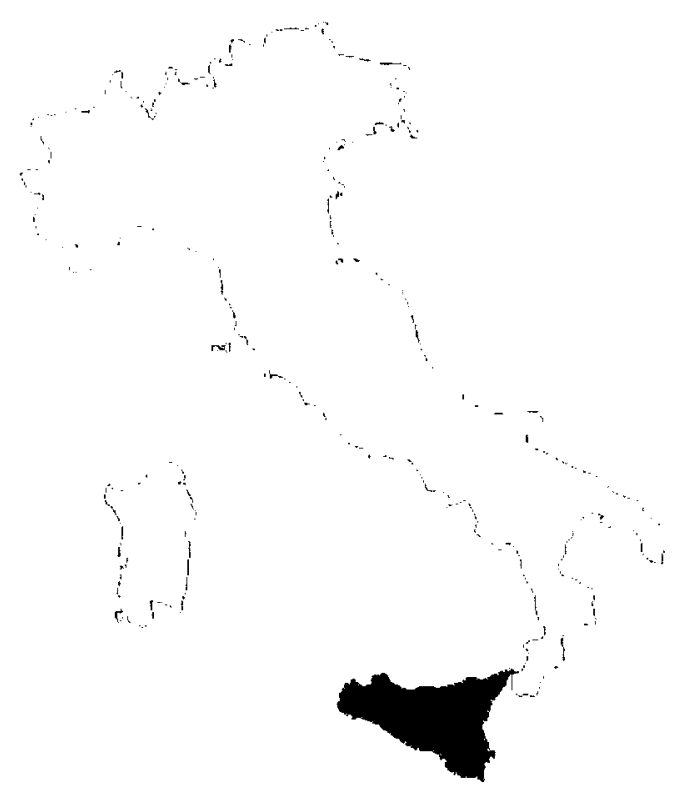

Favara, a city in western Sicily, sprawled uncontrollably following the world wars with no planning regulations in effect. The historical city centre was slowly abandoned and began to decay. Today, socially rooted locals seek to reconnect this portion of the city within the larger urban context while the municipality has begun to demolish portions of it. The locals are catalysts of changing social and cultural spheres and their efforts to ameliorate the city embodies the spirit of the Favara; the genius locus which the design proposal aims to reflect. The methodology encompasses a literature review, urban analysis as well as fieldwork visits which include interviews and surveys. The research and design project target the local attitude and respond to Favara's urban issues through an urban-architectural strategy. The symbolic social core of the city, Piazza Cavour, in the centre of the historic city is the focal point for this study. 
I wish to dedicate this thesis to the beautiful people of Favara. Their persistence to better their city continuously motivated me through the various stages of this project. I am grateful for their hospitality and the opportunity they gave me to be a part of their community.

I would like to acknowledge those who advised and encouraged my work, advisors both formal and informal; Shelagh McCartney, Roger Connah, Claudio Sgarbi, Paul Reed, and Daniele Pario Perra. As well as my dear friends Rejean Beaudin and Holly Simon, this triumph is also theirs. Special thanks to my faithful studio mate Anna Kourkounakis.

I was taught the joy of community and belonging at a young age by my loving sisters;

Catalina and Vinka, thank you for this. My deepest gratitude always goes out to Adela Meneses.

You showed me how to see the sea from the most faraway places. You are a true model of a

woman in your many facets and continuously motivate and inspire me. Thank you.

Finally, my loving thanks to a wonderful partner, Luigi Bartolomei 
ABSTRACT ACKNOWLEDGEMENTS

2. Armando Giglia

3. Florinda Saeiva

4. Vicenzo Casetlli

5. Michele Vitello

6. Nadia Castronovo \& Carmelo Nicotra

\section{contents}

\author{
AVANT PROPOS \\ INTRODUCTION
}

[1] FAVARA'S DESOLATE PIAZZA

1.1 - Historical Overview

1.2 - Urban Development

1.3 - The Italian Piazza as Urban Social Space

[2 ] THEORETICAL FRAMEWORK:

TRACING THE SOCIAL ROOTS OF FAVARA

2.1 - Genius Loci: Locating the Spirit of Place

2.2 - Local Assets: Grass roots Organization

2.3 - The Roots of Collective Action:

A Composition of Social Rootedness 24

2.4 - Case Studies

[ 3 ] METHODOLOGY: FIELDWORK \& URBAN ANALYSIS

3.1 - Phase I: Favara Residency \& Interviews

3.2 - Phase II: Urban Analysis

3.3 - Phase III: Slte Visit

[ 4 ]URBAN POTENTIAL

45

4.1 -Results \& Discussion

45

4.2 -Piazza Cavour: Existing Conditions

4.3 - Piazza Cavour: Design Proposal

4.4 - Design Portfolio

[5] CLOSING DISCUSSION 


\section{AVANT PROPOS - SICILIAN DIARIES}

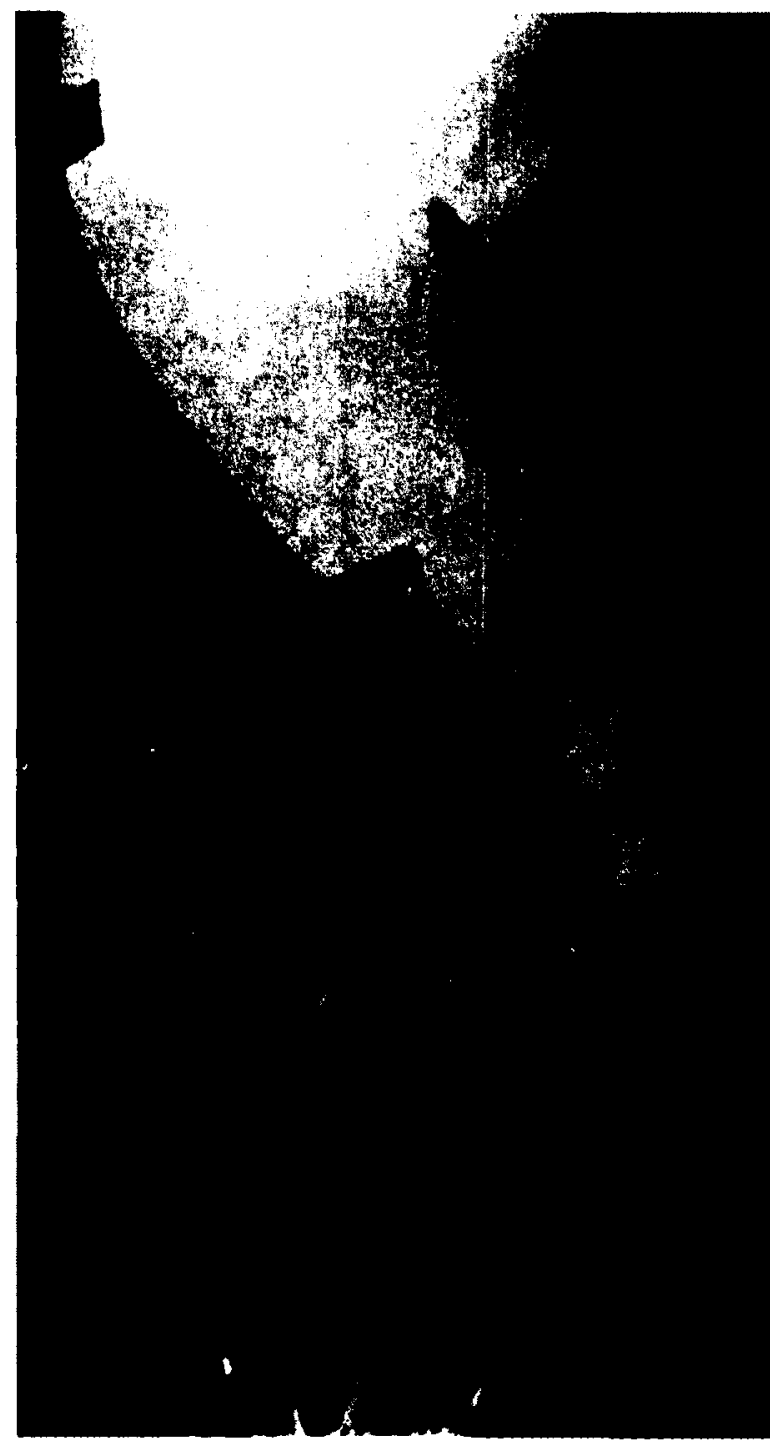

IGURP? ARCOSANII ARILONA

In an attempt to understand the value of community within a city, I recall an internship opportunity at Arcosanti, an experimental "arcology" town in central Arizona, where I worked as a planning intern in 2006. Arcosanti, the life's work of architect Paolo Soleri, is a planned community as an alternative to the way we live, referred to as an "urban laboratory." Soleri stresses that an intention of the project is for its residents to learn its core principles and take them. While living at Arcosanti, I learned that before a community is built, there is an attachment from its residents which will give it form and sustains its development. It is within this phase that people identify with their place and begin to have a sense of belonging that roots them there. The value of belonging in order to generate community development is a concept that I have carried with me throughout my architectural formation as a student, traveler, and resident in the many places that I have lived.

In January 2012, I met a professor who told me that in Favara, Sicily a group of people were "rebuilding" a community. It intrigued and motivated me to move there. From June to August 2012 I lived in the historical centre of Favara and observed the attachment the locals had to their city. I was particularly inspired to see the work of several grassroots organizations who wished to re-engage the local residents through social and cultural events with the long-term goal of reviving the forgotten city centre. Yet, a puzzling discovery was the empty piazza within the historical centre. A piazza in an Italian city is typically a place for socializing, considered a city's meeting place, a point of reference and venue for any event to take stage. It is an integral part of the social fabric of Italian cities since medieval times. Yet in Favara, Piazza Cavour, at the centre of the city, was desolate.

This posed several questions which lead to the development of this research thesis. First, how had this space lost its place within Favara'? In conversation with several local residents, they had expressed their roots to Favara as a motivator for the work they did. For that reason, could socially rooted individuals be a key to revive the historical centre? They clearly demonstrated an ability to generate change within the city, but could this be sufficient? How had the piazza been overlooked as a focal social space to reconnect the locals? Moreover, how would an architectural-urban intervention respond to these social issues and also meet the enthusiasm of socially rooted locals in order to reignite this space? 


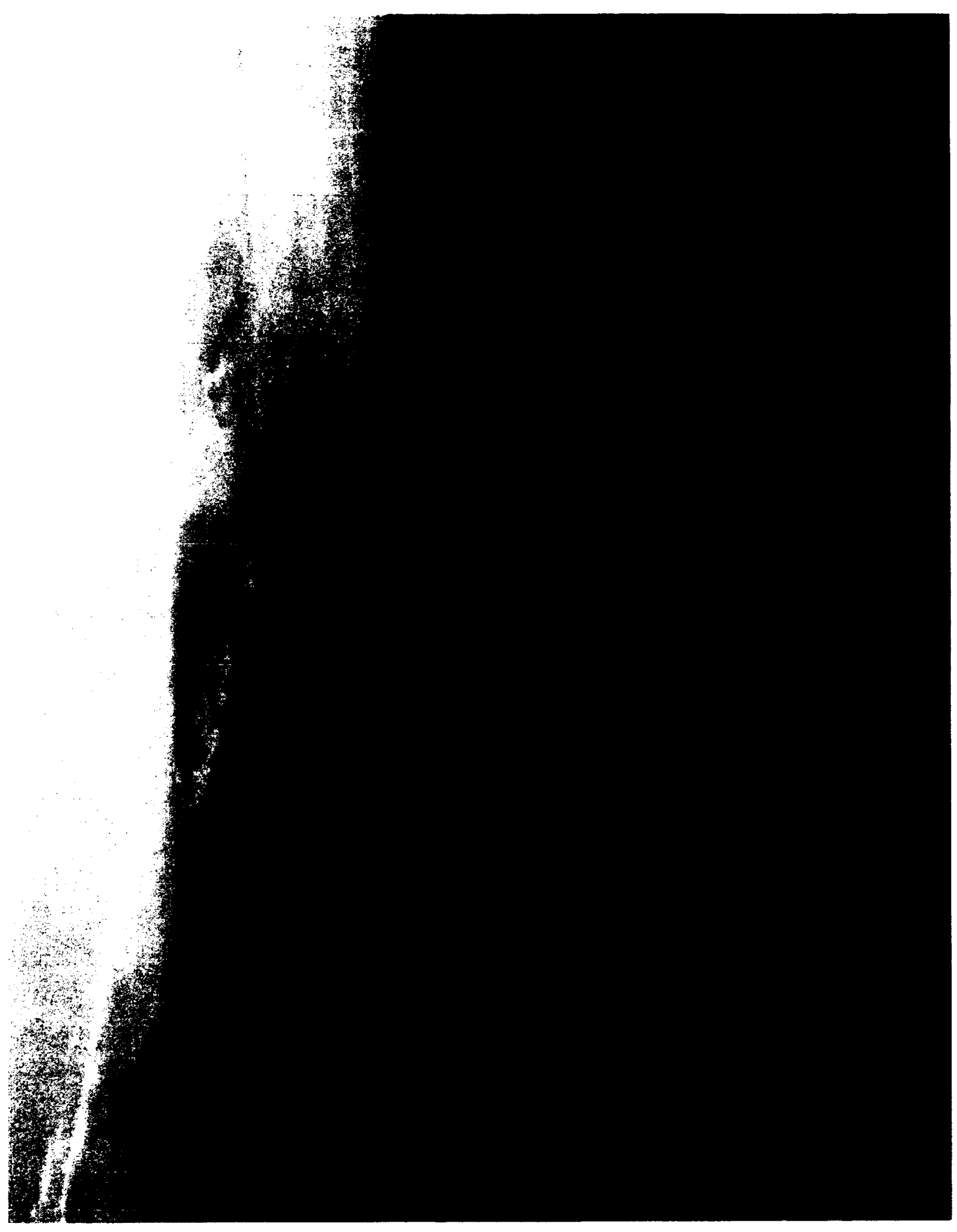




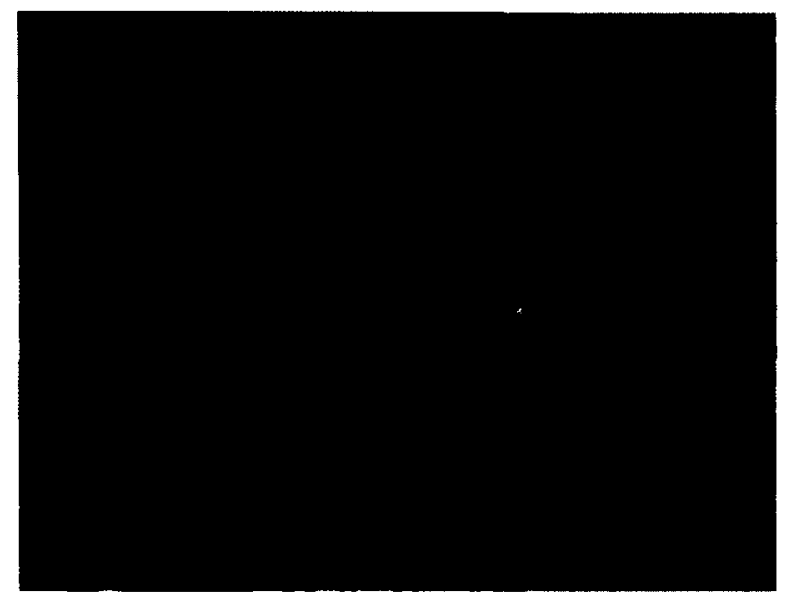

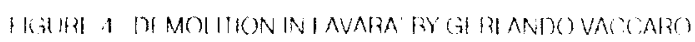

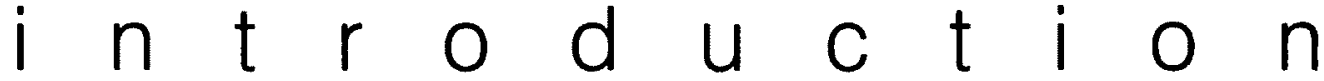

Favara, Sicily, a city of 33,000 people, is on the edge of abandonment and decay. Following the world wars, the city quickly expanded and sprawled uncontrollably with no planning regulations whatsoever. The historical city centre was slowly abandoned, buildings deteriorated, shops closed and families no longer strolled through its main square, Piazza Cavour. Awakened by the tragic death of two children buried under a collapsed historical building in 2010, the city began a demolition strategy in the name of 'salety'. At the same time, between 2008 and 2010, three major local grass roots groups formed, all with the similar intention of ameliorating their crumbling city centre. The determination to revive Favara, demonstrated by members of the local groups Sicily Foundation, FARM Cultural Park and Associazione Culturale NICODEMO arises from their attachment to the city and social roots to the community. Their persistence is demonstrated through social and cultural events they organize that have begun to reinvigorate the city. This thesis was born in reaction to the motivation demonstrated by many of these locals. The astonishing task they have undertaken lead me to test whether their connection - that is, their social roots to the city were a critical element needed to reinvigorate the abandoned city centre. In order to respond to this question and propose an urban strategy that was honest to its location, it rests on the locals' opinions and their responses and reactions to the historical city and Piazza Cavour. The proposed urban strategy presents an inclusive design for a social space that does not rely heavily on specific building function or economic conditions. Instead it builds from the very energy of its locals, from their volition, energy and deeply embedded roots to their city.

In order to reconnect the historical centre within the urban tissue of Favara, the built environment of the city must be examined. How would an architectural-urban intervention respond to urban issues and reignite the social spaces in the city? Beginning at the symbolic social core of the city, the piazza, can serve as a catalyst for urban regeneration.

An Italian piazza is part of a city's social and urban fabric, and therefore, integral to city life. Culturally and historically engrained within a city, a piazza cannot seize to exist. While its purpose can change, be it as a religious, political, or mercantile centre, it 


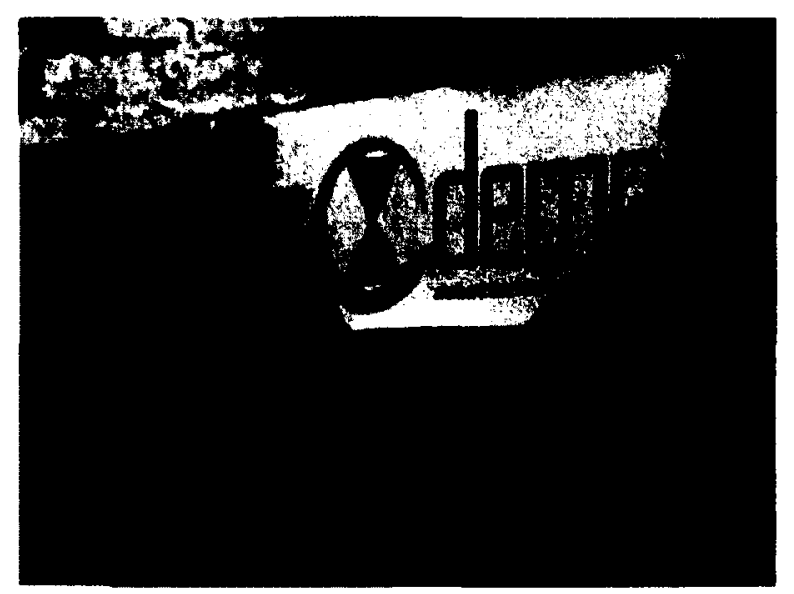

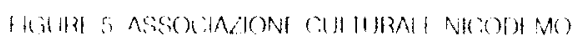

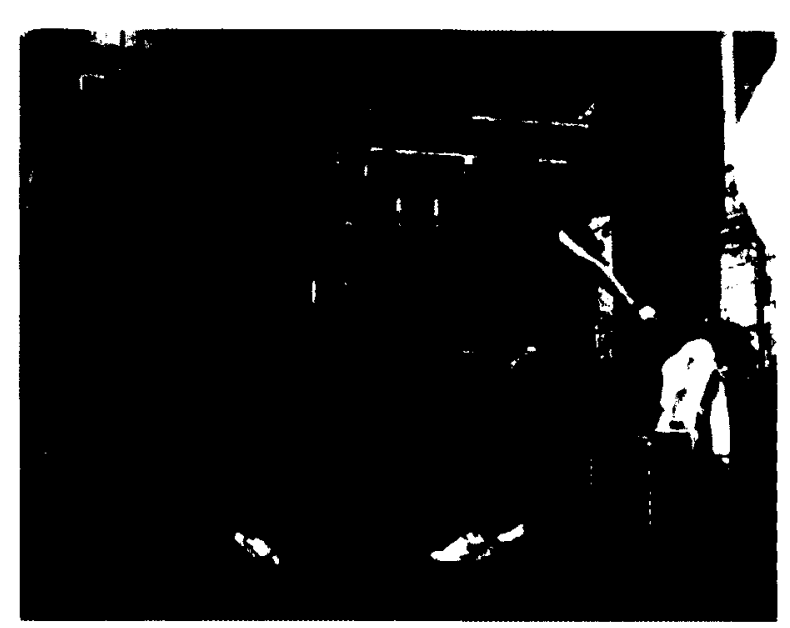

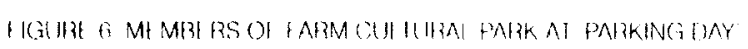
I AVARA SIPT ?OI? has the ability to renew itself because it remains open, public and ideally a social space that responds to a cultural context. The 'spirit' of the piazza is embedded in itself, what Norberg-Schultz refers to as genius loci, that which gives a place 'character'. He states that despite changes and length of time, a place can retain its genius loci and, therefore, its identity (Norberg-Schulz 1979, 11-14). Furthermore, M. Heidegger emphasizes the role of genius loci in architecture through the act of building; making concrete what will become the space within which man dwells. The emphasis of dwelling is connected to the relationship man has between location and space. "Building, by virtue, constructs locations and joins spaces, thus inherent in its nature is the ability to create dwelling spaces which hold the essence of a place" (Heidegger 1971, 155-57). Norberg-Schultz and Heidegger provide a theoretical framework and point of departure from which the current situation of Piazza Cavour can be addressed (Norberg-Schulz 1979, 67). Therefore, it is essential that the genius loci of Favara be understood.

In seeking the spirit of Favara, a close look at the recent formation of various grassroots organizations reveals a sense of belonging and rootedness among some of the locals. Members of Sicily Foundation, Associazione Culturale NICODEMO and FARM Cultural Park share two things in common: first, they wish to develop their city socially, culturally and economically and secondly, as Favara natives this has become a personal battle. Samatha Virone, a founding member of Associazione Culturale NICODEMO, states "it's a bad habit to love this place," yet this very notion is the motivational factor for her as well as for members of all groups. Being of a certain place and identifying it as home proves to be a strong element for them. Building from this finding, this section of the research will attempt to rationalize their collective behaviour with the intention of revealing the value of belonging to a place and its potential in community change. The behaviour they share will be labeled as social rootedness within the thesis. The term is borrowed from the social sciences and will be described using the concepts of community, attachment, identity (self and group), sense of place and belonging. These sociological terms are used with the purpose of enriching previously mentioned theories by Norberg-Schulz and Hiedegger of intangible and non-physical qualities within architectural inquiry. The city locals embody the genius locus of Favara and will therefore be fundamental in the design proposal for Piazza Cavour. 


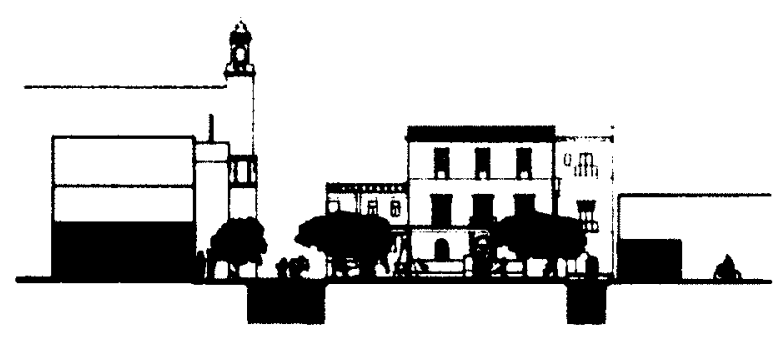

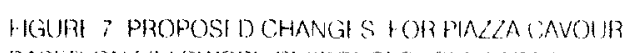
BASH D ONIIII IOWOHK BI SPOONSS SS SH PNBI 3
The methodology in this research thesis uses a mixed-method approach with an anthropological perspective and is divided into three phases. The first phase was a short term residency within the historical centre of Favara during which many of the questions that came to form this thesis arose. At this time several interviews were conducted with key members of the already mentioned groups in order to source the root for their collective action in Favara. These interviews revealed motives for wanting to revive Favara and further emphasized their social roots. The second phase of the research involved an urban analysis of the city through mapping exercises. The city was studied in order to locate a hierarchy of social hot spots for lingering in Favara and revealed a lack of these within the historical centre. Although there are currently three caffes at Piazza Cavour, there is no network that connects them to the city. They are isolated from the busy street life that occurs along SS122 [Corso Vittorio Veneto]. In addition, the second phase of open public spaces revealed a series of piazzas, an abundance of cortili and private courtyards, all of which are fairly disconnected from each other. Consequently, from this phase of the research the micro social culture of the cortile was exposed. The cortile was historically a social hub of residential life. Derived from the building typology of Favara's historical centre, traced to Arab influences in the $11^{\text {th }}$ century, the cortile is contained within tight narrow roads similar to an interior courtyard. These spaces, though technically public, have only a degree of publicness since it is socially understood that only the residents that share the space linger there. The cortile study exposes critical dimensions from cortile to major roadways and between cortili. This is significant since it reveals a local urban condition rooted in centuries of building history that continues to dictate inner city travel and dimensions for what is considered a comfortable public social space. Today, the inhabited cortili of Favara continue to be used as social spaces, such as Sette Cortili where the ladies bring their dining room chairs outside in the evenings to talk and children ride their bikes. The third phase involved a site visit to Favara which targeted Piazza Cavour and sought to learn what the locals wished to see change at the piazza. Participants were reached via radiolNAgrigento, as I was able to have an hour time slot each day for a week to talk about the piazza and ask locals what they wanted. Other participants were reached via online social networking (Facebook) and in person at the caffes in Piazza Cavour and surrounding area. Key findings from participants were considered for the design proposal. 


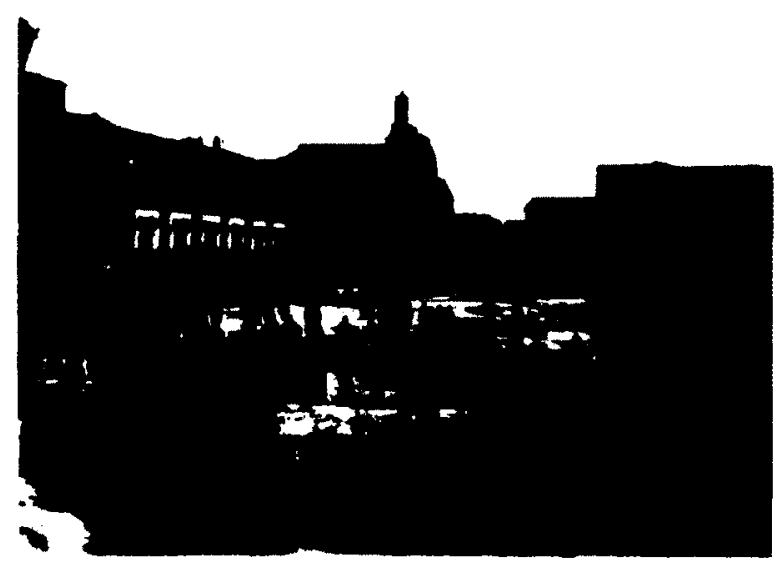

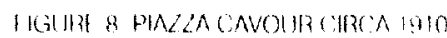

The phased methods of this project were designed with the intent of targeting the social roots and layers of social and urban decay in order to propose an appropriate architectural-urban strategy. The project proposal is aimed at a newly designed Piazza Cavour and its surrounding area, which is rooted within the local conditions and sentiments of Favara's locals attempting to reflect their spirit.

The urban design proposal responds to the fieldwork results, and the city and cortile analyses that reflect local conditions and concerns. The proposed project aims to weave the historical city back into current day Favara. At the core of this proposal is Piazza Cavour, considered to be a catalyst in this mission because it is historically engrained as Favara's central social space. The major element of design is water, through the design of a water system and fountain with the focal point beginning at the Piazza Cavour. The materials and design language used in the piazza are carried out onto the adjacent roads that define the limits of the historical city. 


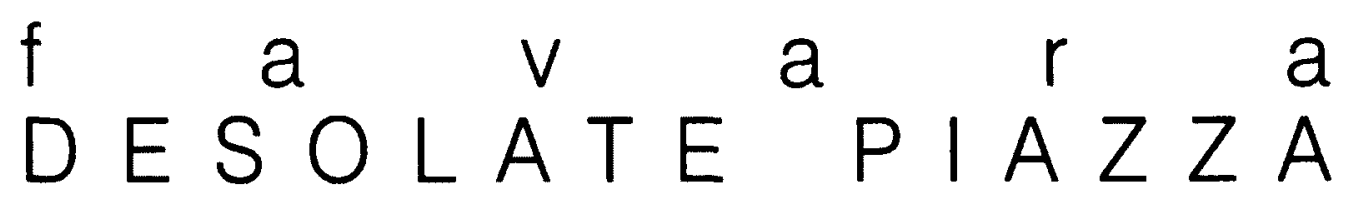

Piazza Cavour is the starting point from which this inquiry stems because it no longer serves as the central social space in the city. Similar to much of the historical centre, where it is located, Piazza Cavour came to be forgotten. Understanding how the city and piazza arrived at this situation is critical before an analysis of theories, literature review and design possibilities which can offer insight to remedy the situation. Firstly, this section provides a historical overview of Favara, its recent urban development and exposes current urban and social issues. Secondly, the history and role of the piazza in Italian urban design supports the purpose of situating the design proposal at the piazza. Finally, the current state of Piazza Cavour is discussed.

\section{[1.1] Favara: Historical Overview}

Favara is located in the province of Agrigento on the southwest side of Sicily. Its area is no more than 89square kilometers and has a population of approximately 33,000 . In the Historical Guide of Favara by Sciara (1997), the city's history begins with the discovery of ceramic pieces and unmarked graves dating from 1900-1450BC. Its early foundations are attributed to Etruscan settlers and the Greeks, followed by the Arabs who would

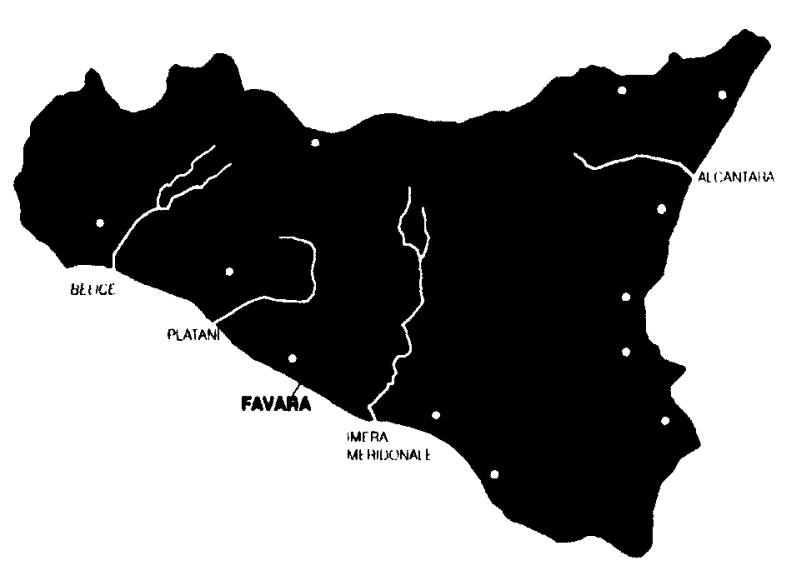

1. KGUHA a MAP OH SHCIIY

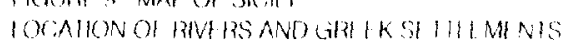
leave a long lasting mark on the city's history and built environment. Under Arab control (711-1065AD) the city received its name, Favara. From the Arab word Fawârah, Favara means 'spring of water that flows forcefully, almost boiling'; it's major water supplier being the river Imera Merdionale, the largest in Sicily. Similar to most towns settled by the Greeks and later developed by the Arabs, its proximity to a major source of water allowed for it to develop as an agricultural town. Favara's city centre and central piazza, Piazza Cavour (originally named Piazza Castello), came to be defined in the $13^{\text {th }}$ century. Traces of medieval walls dating from this period enclosed Favara's population of 51 families (approximately 250 inhabitants) until the $14^{\text {th }}$ century when it expanded beyond these limits. By 1479 , the population stabilized and continued to increase as sulfur mines and tanneries opened nearby. Advanced technologies for irrigation allowed for increased agricultural yields generating powerful industries under which the city would flourish. As industries developed, a bourgeoisie class strengthened between the $17^{\text {th }}$ and $18^{\text {th }}$ cen- 


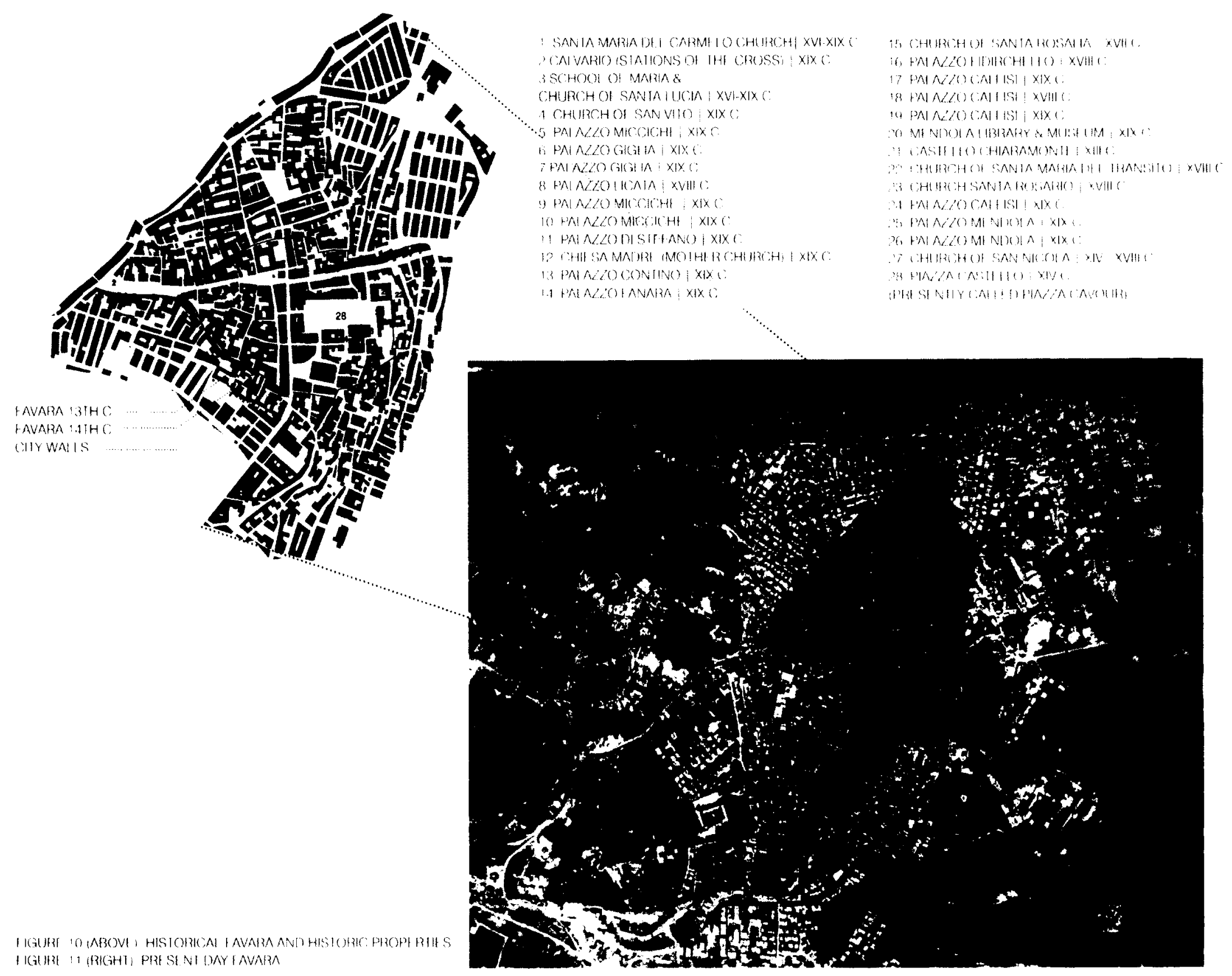




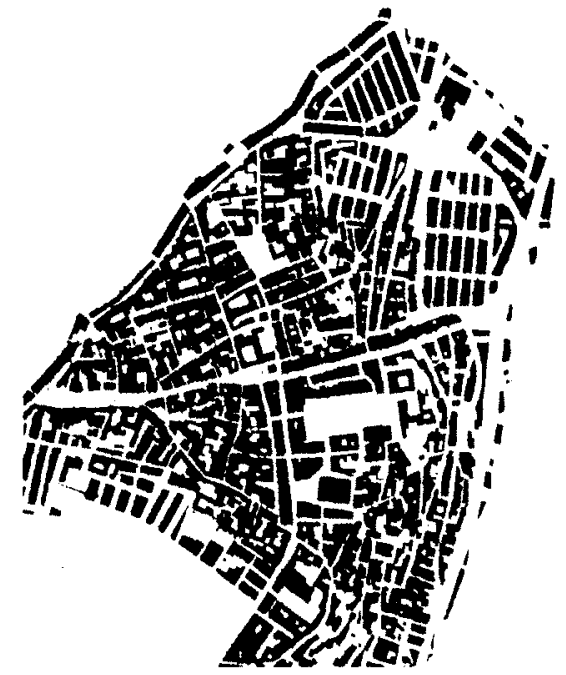

(1)

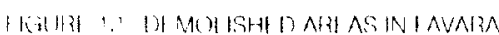

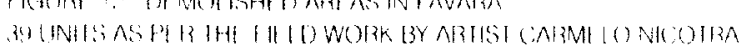

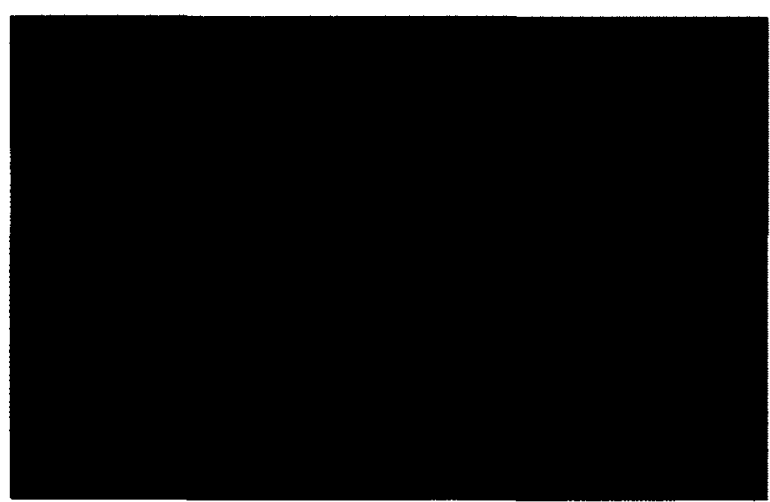

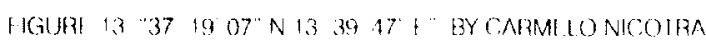

turies, population increased' and new buildings appeared near Piazza Cavour. These included churches, convents, and large estate homes of wealthy families (Sciara 1997, 5-10). This development continued steadily into the $19^{\text {th }}$ century despite organized crime which began to shake the city with fear. ${ }^{2}$ The Mafia gang Fratellanza, translated as 'Brotherhood', was known to operate in this area, using violence and intimidation to seek recruits at mines and control much of the local economy. The early $20^{\text {th }}$ century continued to rattle Favara's previous periods of growth and stability; the occurrence of the worid wars, as well as sulfur mine closures, and waves of immigration laid the foundations for Favara's subsequent phase of urban growth.

Following the world wars, the city witnessed a rash of unregulated urban sprawl that would last until the early 1990s and prove to be detrimental for the Favara's historical centre. Non-existent planning regulations allowed for unpermitted building; locals built larger homes outside of the city and abandoned the historical centre. As this area came to be less frequented, stores closed and families no longer strolled through its main square, Piazza Cavour. The majority of the housing stock in this area has been neglected for years, and deteriorated buildings have proven to be fatal. When two children were killed under a collapsed historical building in January 2010 , the issue of safety and structural integrity was finally brought to the attention of the municipal government. Shortly after the incident, the municipality evacuated several families within the historical centre (Russello 2010) and demolished historical buildings, leaving pockets referred to as "white zones" or dead spaces sprinkled throughout the old city. Between January 2010 and February 2011, the local artist Carmelo Nicotra documented 39 demolished buildings and gathered ruin traces for his installation " $37^{\circ} 19^{\prime} 07^{\prime \prime} \mathrm{N} 13^{\circ} 39^{\prime} 47^{\prime \prime} \mathrm{E}$ " exhibited at the gallery Zelle Arte Contemporanea in Palermo (Spring 2011). A growing interest surrounding the role and preservation of the historical centre surfaced. At this time and even a few years prior, several locals formed organizations, which aimed to address this issue of abandonment within the centre and design strategies that could reinvent the historical centre's identity and social spirit. Their persistence in changing their city's current situation reveals their sense rootedness and its potential in community change; these organizations will be further discussed in Chapter Two. 


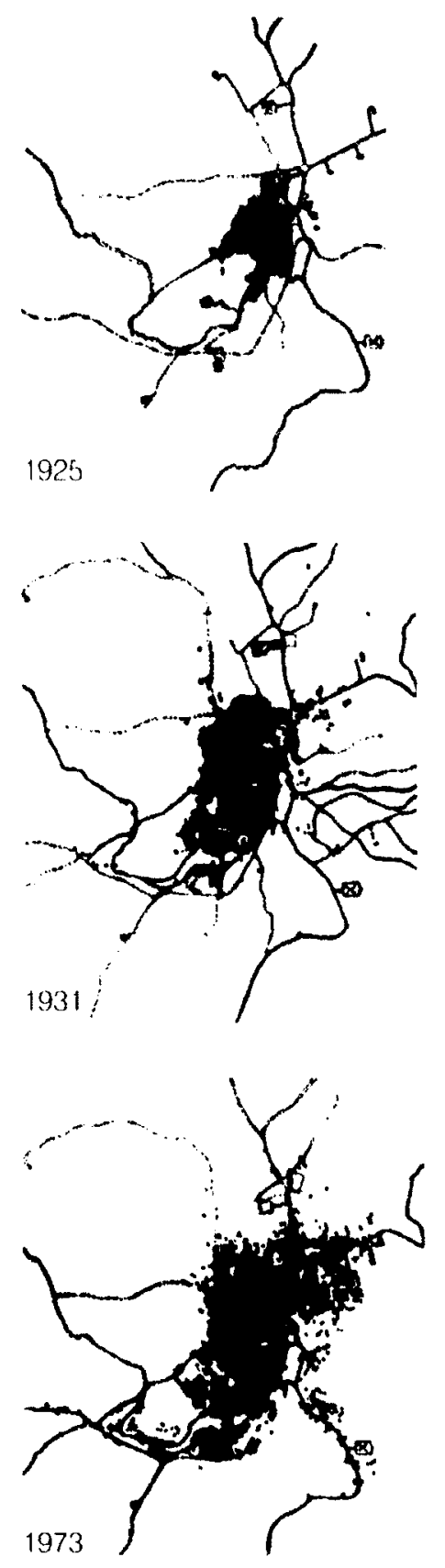

\section{[1.2.1] Favara: Urban Development}

The deserted city centre in Favara was brought about primarily because there were no planning regulations in place to control city expansion and prevent ad hoc building. Italian city growth is controlled through the use of a municipal regulating plan called the Piano Regolatore Generale (PRG). The PRG is a tool for controlling urban expansion and generating a long-term vision for a city. Designed for a 25 year period and required for all cities with a population greater than 10,000, it was introduced and implemented throughout Italy by the National Development Planning Act n.1150 of 1942. According to this act, when a plan has been adopted by the city, it must be published and displayed for 30 days. Residents are free to voice opinions and concerns, which must be addressed by city council and then a new plan must be submitted and made public once again. ${ }^{3}$ Favara's first and only PRG is from 1987. Given the 25 year lifespan for a PRG the city should have presented its new plan in 2012 but nothing is available at the municipality or at Technical Department of the city. The Technical Department of the Comune of Favara acts as the engineer, designer and planner for the city; there is no Urban Planning Department. However, the root of this problem precedes 1987: why did Favara not adopt at PRG following the world wars? By 1951, well beyond the creation of Act 1150, Favara's population was $25,645^{4}$ and steadily growing, hence in need of an urban plan.

With no PRG, planning regulations or guidelines locals were not accountable for their actions and neither was the city. Residents built how and where they wished. This is evident when looking at a city plan: unauthorized (unpermitted) constructions were arranged at odd angles to suit the topography, creating very steep roads that often required stairs. The city's historical $13^{\text {th }}$ century cruciform plan, defined by Via Umberto and Via Vittorio Emanuele that delimit Piazza Cavour, began to take a diamond shape as houses were constructed at exponential rates. This trend began in the 1950s and only slowed down by 1990 as it continues today, even with the 1987 PRG in place. 


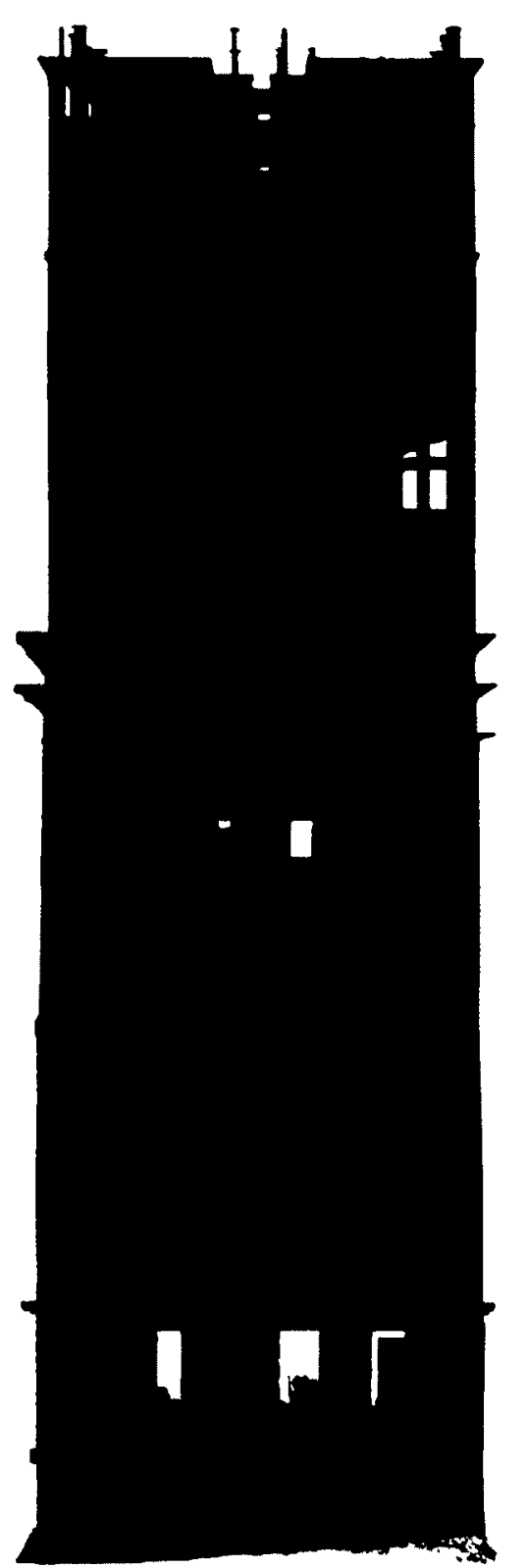

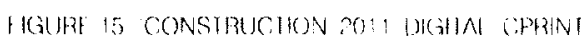

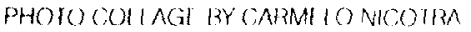

Unauthorized building generated a surplus of housing that was disproportionate to the rate of population increase (see chart: population vs. units built). This development triggered a parallel shift in urban density leaving much of the historical centre uninhabited. According to 2010 zoning data produced by the Regional Government of Sicily, Favara's population was 33,924 in 2008 . The population of the historical centre was 6,708 , just under 20 percent of the city's total population for that year. Furthermore, statistical data from 2001 indicates the number of habitable housing units available in Favara to be 25,311 units, 18,888 considered to be habitable leaving 6,423 vacant units, ${ }^{5}$. Favara's abusive over building is openly recognized by Sicily's GIS and Planning department (Regione Siciliana - S.I.T.R. Portale WebGIS 2010) since it has its own zoning designation. The 2010 zoning plan defines various zones: zone B1, called "Consolidated building" and zone B2 called "Abusive building and/or unstable territory." The Urban Zoning Map for Favara (pg11) reveals the extent of these periphery zones and combined populations in contrast to the historical centre.

Beginning in 1946 and peaking between 1972 and 1981. Favara built more homes than was an increase in population. This phenomenon is attributed to Italy's 'Economic Miracle' or 'Economic Boom' following WWII. Increased production and new industries developed much of the northern regions at this time, although it is noted by Scrivano $(2005$. 320) that Sicily and much of southern Italy did not benefit. However, the statistics of built dwelling units in Favara might suggest otherwise as housing numbers only increased (see chart: population vs. units built).

\section{[1.2.2] Favara: Current Issues}

[The Morphology of a City] | The growth of Favara's housing units has not ceased; new buildings and additional floors are 'illegally' added to homes as seen in the photo collage of local artist Carmel Nicotra, 'Construction_2011_digital c-print'. In light of this, it is unclear how a new PRG could prevent this phenomenon from continuing. It is also uncertain when this new plan may come into place and which issues the city will address for a long term vision of Favara. Changes in the built environment through continued abusive building is contrasted with continued demolition. White zones, as described by the local architect Michele Vitello, 'are like cemeteries, reminders of the 2010 tragedy' and with so many in the city, he stresses that something must be done ${ }^{6}$ 


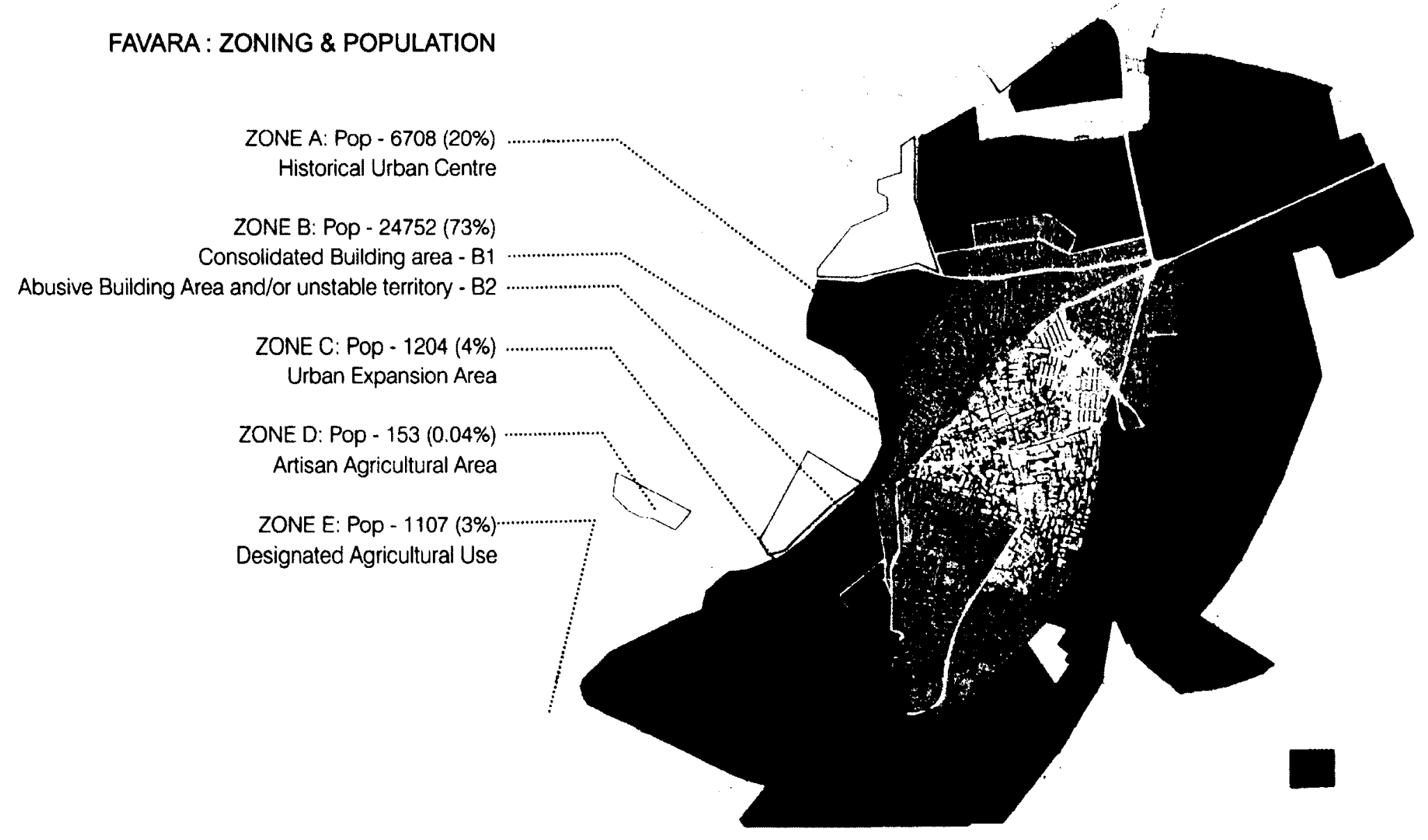

FIGURE 16: FAVARA: Population Increase v.s Units Builts

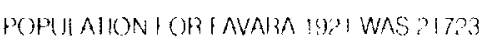

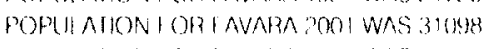

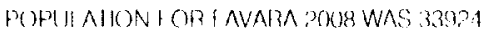

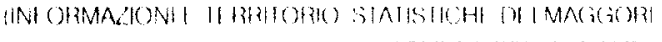

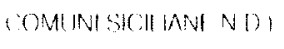

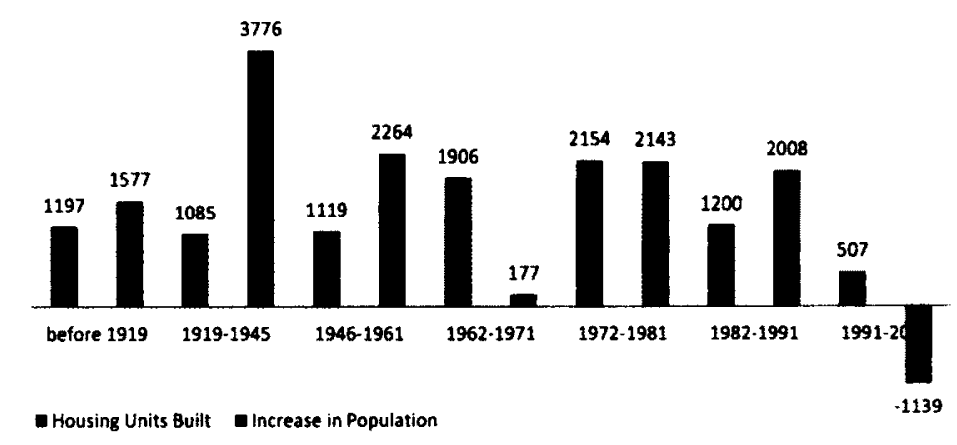




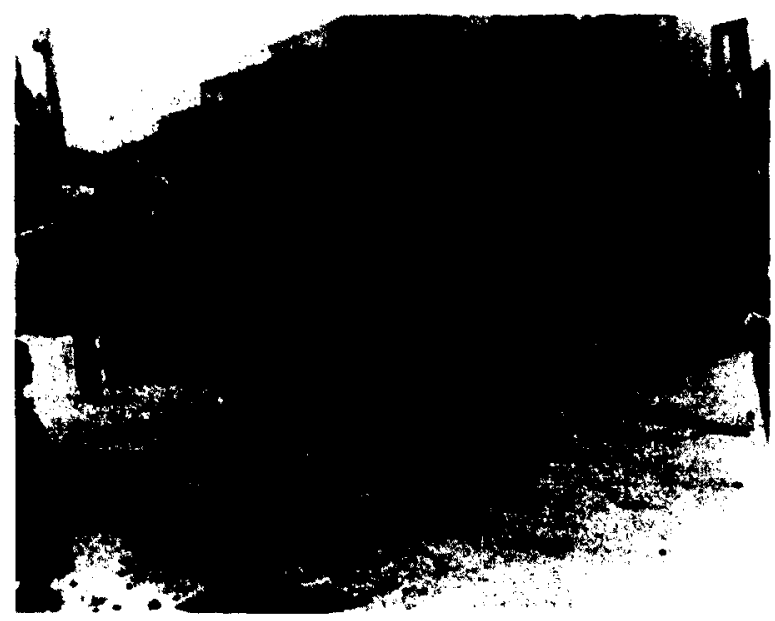

I KOUHAI TE AI IARGOOCANAI IONIANA I AVARAC: 1910 IHH

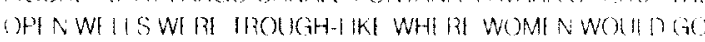

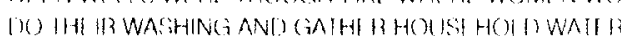

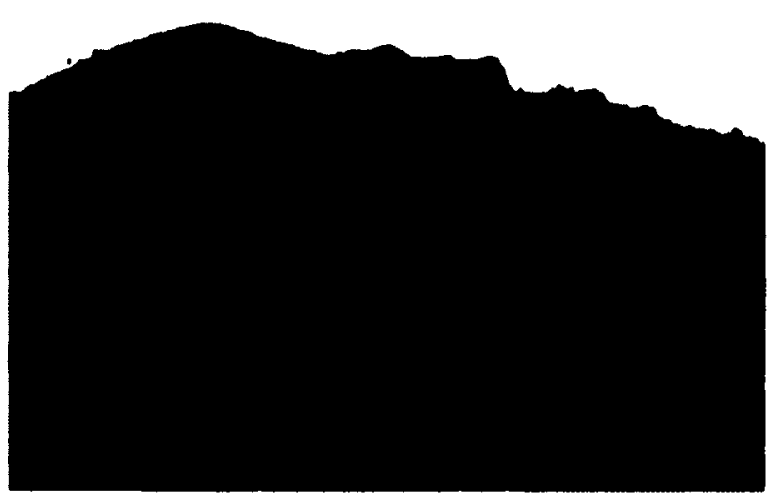

IIGUIRI IO FAVARA WAIERIN IHE SKY

IMAG IAKEN HBOM CASSIIIIOC CHIARAMONII IOOKINGIIAS!
[Water, Water Everywhere] | Favara has a number of imperceptible urban issues that affect the locals' well-being and social development, the first of these being water shortages. Despite Favara's proximity to the river Imera Merdionale, water shortages occur every 8 to 10 days and can occasionally last two days. This is common for many residents of Favara as well as those in the region of Agrigento. Water was once controlled by the regional government of Agrigento, yet even at this time there were reported shortages, attributed to 'poor pipe connections'. In 2000 the region received a grant from the European Union for water and sanitation services which was to be used by 2006 (Petrotto 2012). At this time the water was sold to a private company called Gigenti Acque SpA and plans for desalination plants in Gela, Favara and Porto Empedocle were proposed. Water prices increased but distribution remained the same. Water flow is continuously lost in Agrigento's cracked up pipes and "is washed back into the sea" (Gian Antonio 2007). Not even with the new desalination plants, did shortages cease. The people of this region, including the Favaresi, have adapted to shortages and those who can afford a private reservoir tank on their roof do not notice when the city dries up. These blue tanks dot the skyline, some large enough to hold 30,000 liters. The other reality is lived by those who do not own a personal water supply and adjust by using plastic plates and filling every container with water when it is available. In a recent article published on FavaraWeb, an appeal was made by the Comitato Beni Comuni di Favara (the Committee for Public Goods of Favara) to the mayor of Favara to stop Girgenti Acque from cutting the water lines to those who cannot afford their inflated prices. The committee reminded the mayor that "it is his job to serve his city and thus defend their human right to water" (Vinciguerra 2013). When water is lacking, the life of a cortile changes; it is deserted. Neighbours do not gather in the evening and laundry does not drape over balconies. The life of a cortile shuts down. An underlying current segregates those who have access to this basic human need and those who do not and generates micro cultures within Favara 


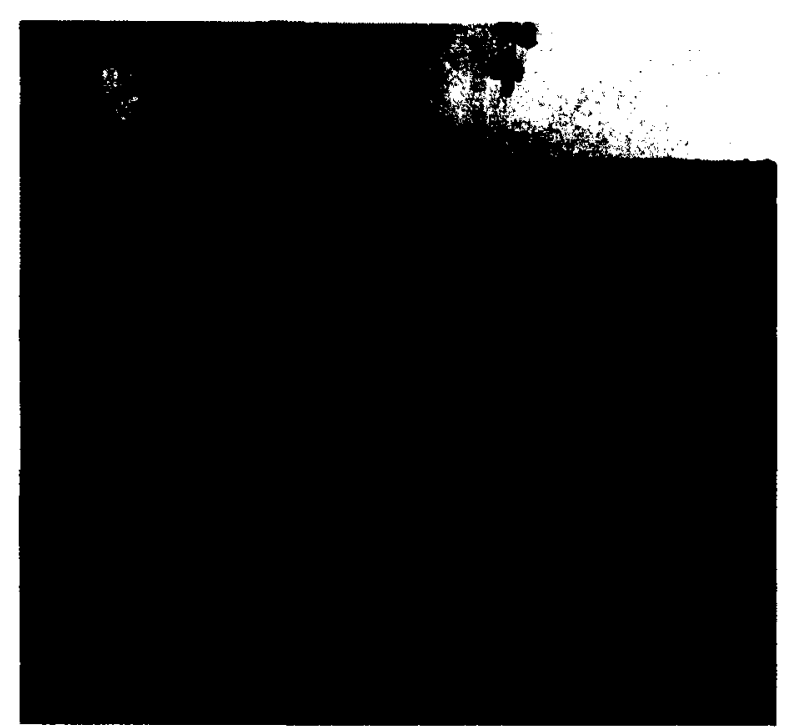

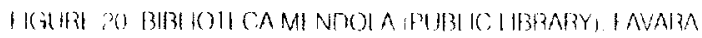

[Access to Public Space] | Viable social spaces in Favara such as the public library and public pool are closed to the locals. The historic public library, Biblioteca Mendola, located at the east corner of Piazza Cavour, has been closed for over 20 years. The municipality states that it does not have the funds to keep the doors open. Instead, they run a one-room library inside the municipal offices. Meanwhile, a rare collection of original travel journals by Italian Anthropologists, a rare copy of the drawings of the Church of Montreale in Palermo, a collection of original periodicals of Giornale della Sicilia including its first publication in 1860 and other books remain behind closed doors gathering dust. The fact that this building and its books have been unavailable for over 20 years means that more than one generation of young children and adolescents have never been inside or know what it has to offer. Similarly, the city pool was closed in October of 2011 because of an "electrical malfunction that failed to warm the water to a comfortable level" (Vinciguerra 2011), It has not reopened since and the city has not stated when or if it will reopen. The closure of these two spaces represents more than inaccessibility to rare books or a swim lane. These spaces allow for activity, for interaction and most importantly they are public services which young people, families and children could benefit. They are opportunities to see others and participate in something enriching for city life. However, it is clear that the local government of Favara can easily close public spaces. Likewise, restaurants, stores, and cinemas can change or go out of business. When this happens, what space can still belong to a city, to its locals? More importantly. how can this space attract people if what is has to offer is itself, the space enclosed by the buildings that contain it? 


\section{[1.3]The Italian Piazza as Urban Social Space}
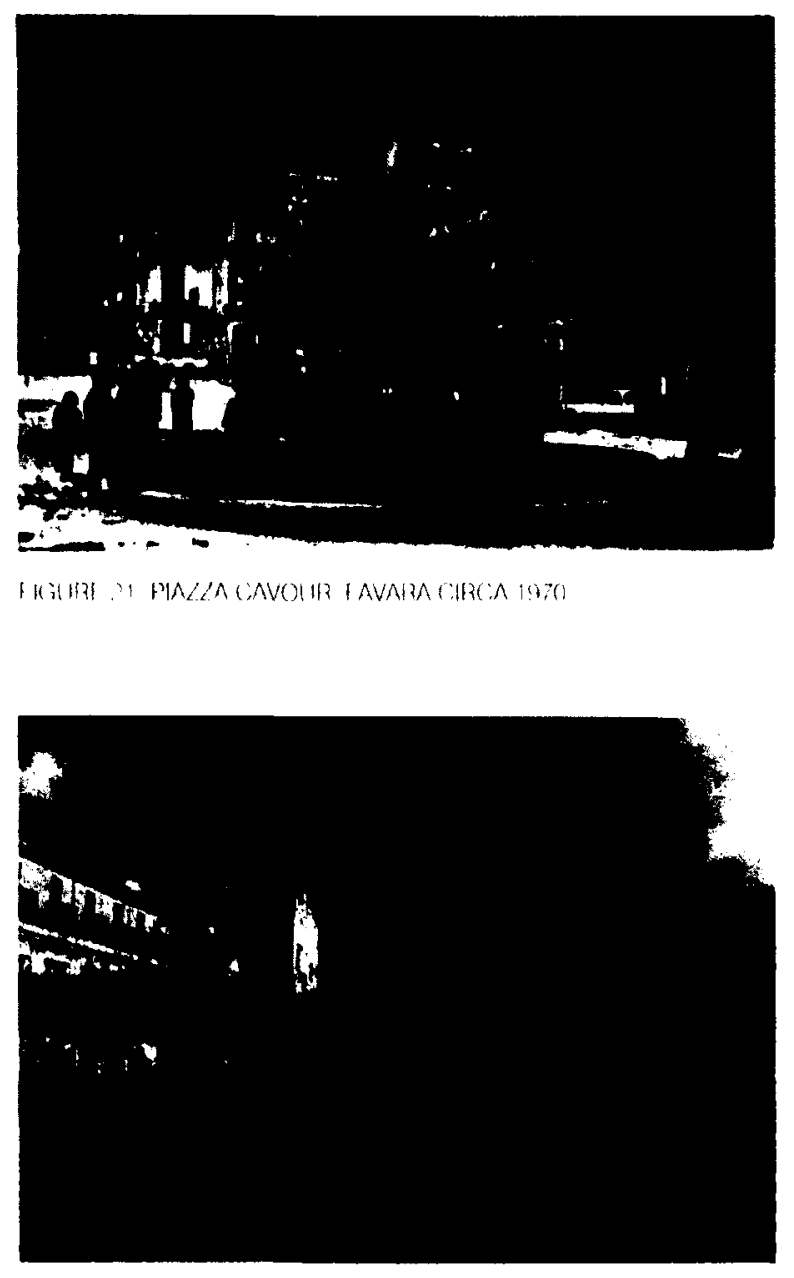

HGHHI W PIALLA CAVOUR F AVAKA ?OL?
An initial inquiry of Favara revealed an emptied historical centre and a desolate piazza at its centre. In addition to the many urban and social issues the city struggles with, the empty piazza suggests that it is no longer recognized as the social meeting space in the city. It is crucial that Favara's urban tissue be reconnected, beginning at the symbolic social core of the city, the piazza.

The piazza of an Italian city is typically the centre of social life. Recognized as a central meeting place and urban point of reference, it is essential to any Italian city. In The Politics of the Piazza (2008) Canniffe refers to a piazza as a feature of European urban inheritance, which denotes a form for public open space. It is understood as a type of public life lived outdoors in southern European towns. Its design and origins derive from the Roman Forum, which is based on the Greek agora and Etruscan settlement design (Fusch 1994, 425). Considered to be fundamental to the Italian urban fabric, the piazza is an open exterior space that connects the streets and zones which surround it (Fusch 1994 , 424). Abutted by important historical buildings, a piazza was typically created with a purpose; as a gathering space, a religious venue for processions, for markets, nobility and/or government administration.

During the Roman Empire, the piazza was an urban space that served as an extension of daily life. With the fall of the Roman Empire and the establishment of Christianity as the official religion, cities came to be characterized by Christian building types, which usually adapted previous Roman forms into basilicas. The Basilica building type came to dominate the social sphere, representing open public spaces. Medieval Italian city states represented their political power and autonomy in the forms of its public buildings and spaces. Usually built on the foundations of earlier religious structures, these spaces responded to the political tension between civic and religious powers. Thus, the need to define a new identity in the form of civic palaces and newly defined public spaces came to be embedded in urban space design (Canniffe 2008, 5). In the $16^{\text {th }}$ century Italian states designed piazzas to validate their political agendas using permanent 'scene-o-graphic' architecture that would delineate new and existing spaces and support the social fabric of the state (such as in Bologna, Sabbionetta, Aresso). The piazza was manifested in repetitive linear structures that enclosed new urban spaces, which defined vistas and reinforced the existing civic realm (Canniffe 2008, 6). 


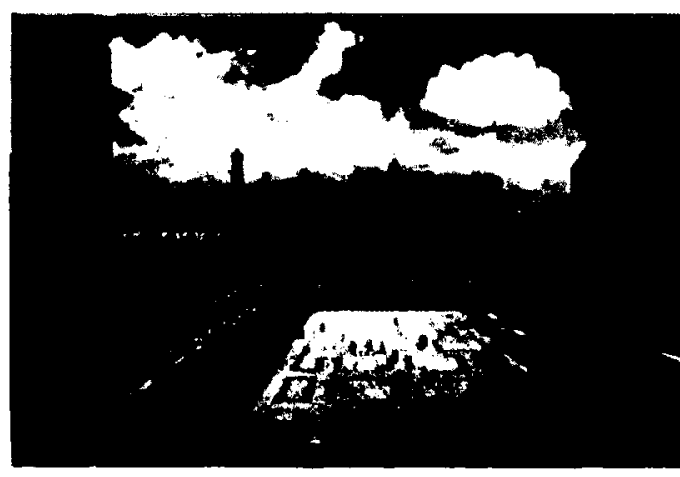

HGIIRZ 93 PIAZLA MAGGOBI BOHOGNA IAAYY, WGO

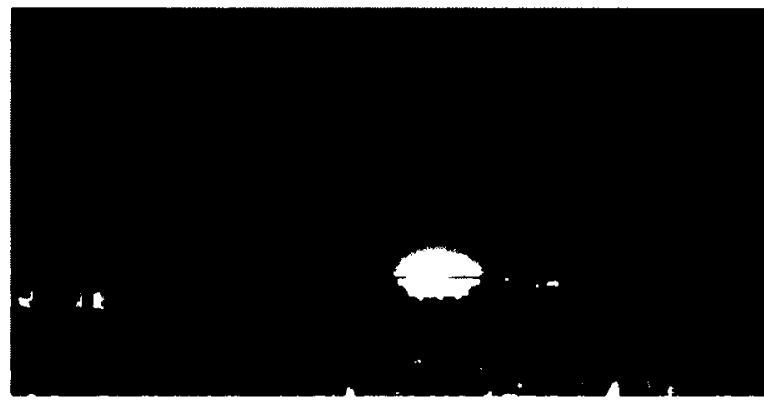

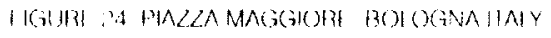

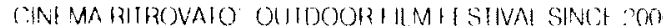

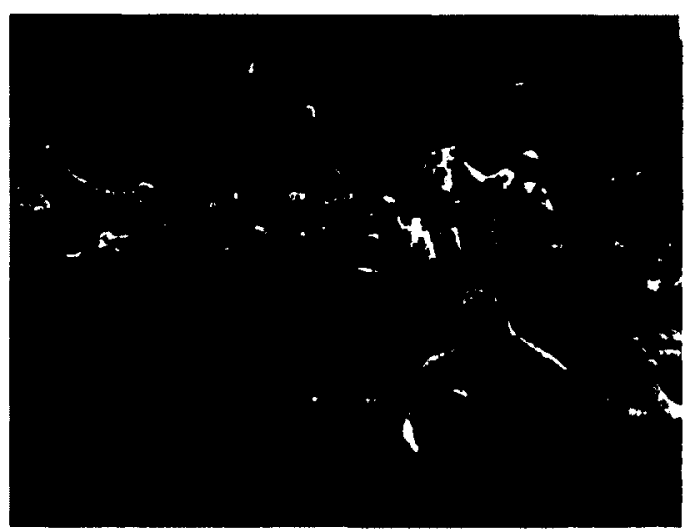

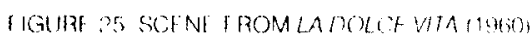
NI IHE IFZI VIFOTINIAIN ROMI IIAIY
Following the Unification of Italy in 1860 , the need to legitimize and promote the new power system was accomplished through public works. Specifically during fascism, a monumental language was born in the architecture of buildings and urban design. At this time the piazza served as a massing space intended to promote political conformity (Canniffe 2008,8 ). In the postwar period much of ltaly had to be rebuilt and so a withdrawal occurred in urban space design as funding and architectural focus was on housing. By the early 1960s Italian urban design reemerged and began to reconsider the role of the piazza as public space, specifically its value as an open space dedicated to pedestrians. Bologna was the first city to remove the vehicle from its central Piazza Maggiore in 1968. This demonstrated a validation for the aesthetics of the urban environment and soon after many cities followed similar plans (Canniffe 2008, 218). According to Canniffe, the re-appropriation of public space was reflected in Fellini's film La Dolce Vita (1960). In the famous Trevi fountain scene public space was, for the first time, represented as a place void of any political meaning or historical memory. The piazza is rich in visual appeal and used by actors as a backdrop in a highly sensual scene which broke traditional rules of cultural conduct as the lead actress walks into the fountain. ${ }^{7}$

The history of Piazza Cavour in Favara reflects that of the historical centre. As people moved away, commercial activity followed, as did social life. Many of Favara's storefront shops, cafes and bars moved along major vehicular roadways. At one point in time there was a central fountain in Piazza Cavour. However, like the shops, it also disappeared. It is unclear when or why the city removed it. Though many young people have no memory of it, it was within the top five responses of what the locals wish to see in Piazza Cavour (these fieldwork results are further discussed in Part 3). Therefore there is a collective memory of a fountain which the Favaresi hold on to. Today Piazza Cavour is a vast open space with an obelisk that commemorates WWII soldiers at the east end. It functions as a sort of roundabout for cars in the city since the main roads in the historical centre are oneways. Redirecting movement back into the historical centre and recapturing the piazza as the meeting space requires more than a few new shops. It is necessary to rebuild the identity of the piazza in order to connect it to the city. A piazza has the potential to revive its identity because it is engrained within the collective memory of the locals as an urban social space. Its genius is that it can maintain this stronghold and adapt to new conditions 


\section{ENDNOTES}

1. Between 1861 and 1901, Favara's population increased from 12, 859 to 20, 403 (Informazioni e Territorio. Statistiche dei maggori comuni Siciliane n.d.)

2. Between March and May of 1883,200 people were arrested in conjunction with this group: and police began digging up bodies from wells, mines and hillsides (Dickie 2004, 79)

3. In conversation with Giacorno Sorce, architect for the Technical Department of Favara.

4. (informazioni e Territorio. Statistiche dei maggori comuni Siciliane n.d.)

5. Informazioni $\theta$ Territorio. Statistiche dei maggori comuni Siciliane n.d.)

6. Refer to Appendix A: Interview Notes for the full conversation with Michele Vitello.

7. La Dolce Vita became a part of popular culture, not only in thaly but globelly bocause it was able to capture a mass audience. The film present a paradox of a 'sweet life' filled with ence. The film present a paradox of a 'sweet life' filled with
celebrities, late parties, extravagant locations paralleied with the reality of moming hangovers and dystunctional relationships. Its heavy criticism of the Catholic Church continues to be heard in Italian culture and abroad. The film presents valid arguments applicable today and it repealedly referenced by other film makers (French 2008)

FIGURE 26: URBAN FAVARA AND HISTORICAL CITY DECAY (MAGE TAKEN EAST OF PIAZZA CAVOUR)
In sum, this section revealed how and when Favara's historical centre and Piazza Cavour came to be neglected. The inability of the municipality to regulate urban planning facilitated urban sprawl and locals began to leave the historic centre. Years of abandonment coupled with several social and urban issues revealed Favara's disconnect to the historical city to be multifaceted. Furthermore, the history of the Italian piazza demonstrated that it is an integral part of urban design and not the residual space left between buildings. A piazza is a space enclosed and defined by the edge condition of buildings. Designed with a purpose, it has an identity, one which can persist through time. In the case of Favara, the identity of Piazza Cavour needs to be redefined in consideration of its past and present owes. In this way it can embody the spirit of its location and its locals in order to weave it back into the city. Finally, a space which is inherently designated for social purposes must therefore be redesigned at human (non-vehicular) scale in order for it to thrive and once again serve as the meeting place in Favara.

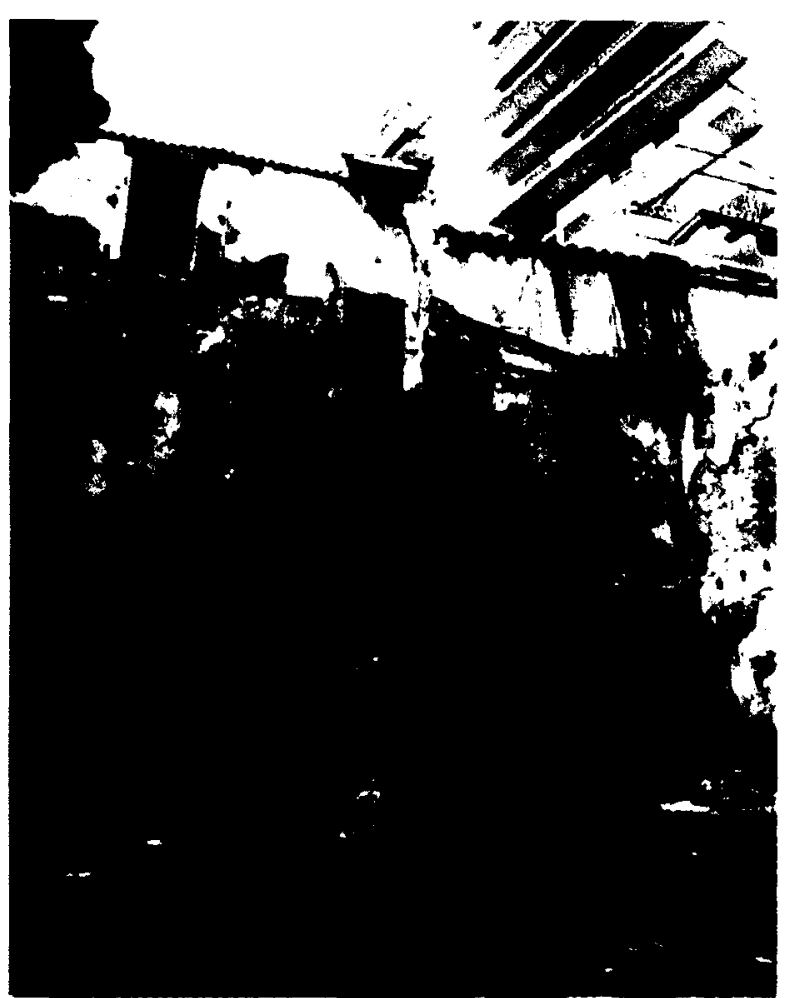




\section{TRACING THE SOCIAL ROOTS OF \\ f \\ a \\ $\mathrm{V}$ \\ a \\ $r$ \\ a}

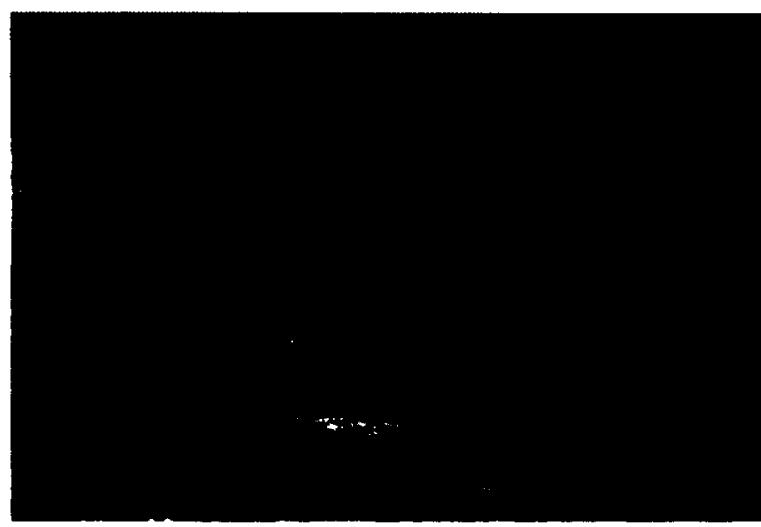

IRIIII $?$ IH ROMANIOHIM ROME HAIY

\section{THEORETICAL FRAMEWORK}

The previous section highlighted the Italian piazza as a vital organ within the composition of the city; one that connects social and urban tissues. As a part of the built urban environment, it is culturally and historically engrained in a city. This is particularly important in the case of Piazza Cavour, whose character and spirit have been forgotten and need to be redefined. This chapter explores three important concepts that underline the purpose of the proposed architectural design project. The concept of spirit of place, genius loci, developed by Norberg-Schultz in Genius Loci: Towards a Phenomenology of Architecture (1979) and M. Heidegger's idea of 'the being' of a place, stated in his essay of "Building Dwelling Thinking"(1971), shed light on what appears to be intangible and non-physical attributes within traditional architectural studies. The third concept, social rootedness, which is borrowed from sociology, is examined through the three grassroots organizations in the city of Favara and their work to revive the crumbling city. Finally, various case studies offer specific design approaches that target some of the urban issues the city of Favara is struggling with.

\section{[2.1] Genius Loci: Locating the Spirit of Place}

Genius Locus is a concept of Roman origin, when it was believed that every individual had a 'genius' or guardian spirit. This spirit is what gave and gives people and places 'character' and the genius refers to what a thing is, inherently. According to NorbergSchulz $(1979,18)$, ancient man experienced his environment as having essence and each place as distinct from another because of character. Recognizing the character of place was important in order for man to come to terms with the genius of his locality or where his life was taking place. A distinction is made between what place and space are. Place is understood in terms of a structure that comprises it, such as a landscape or settlement, whereas Space is the three-dimensional elements that make up place. Character refers to a general atmosphere of any place that is a function of time and can change with local conditions. All places will have character, depending on how a thing 
The elements of a place are there and the strength of the place could greatly be improved if the genius loci is understood and respected."

(Norberg-Schulz 1979, 179) is made, that is, through its technical manifestation (building). Norberg-Schultz summarizes this point as defined by Heidegger's argument of 'Building-Dwelling-Thinking' in the following way, "the existential purpose of building, of architecture, is to make a site into a place, that is, to uncover the meanings inherent in it" (Norberg-Schulz 1979, 15).

Furthermore, Heidegger speaks of genius locus when he refers to the 'being' of a space and argues that while it derives from location it is also dependent on building. He states, "Spaces receive their being from locations and not from 'space'" (Heiddeger 1971, 152). The act of building defines the stage on which a space is made and within which man will dwell. Therefore, the being of a space cannot be lost and will conserve its identity during a certain stretch of time. This phenomenon is created by man through building; man learns to dwell when he is able to concretize the world as buildings and as things (Heiddeger 1971, 157). Through building, man-made places are created to house their individual genius loci.

Considering vernacular architecture, the man-made genius loci ought to correspond to that natural place or setting. In urban architecture, the genius is more inclusive as Norberg-Schultz states; "the genius loci of a town ought to comprise the spirit of the locality to get 'roots' but it should also gather contents of general interest, contents which have their roots elsewhere and which have been moved by means of symbolization" (NorbergSchulz 1979, 58). Thus, approaching the issue of the vacant piazza in the city of Favara at an urban level could better address the issues that are rooted with the city at large and also respond to its inherent genius. While the genius locus of Piazza Cavour is yet to be discovered, the spirit and volition of its locals to ameliorate the crumbling city is ever present in Favara. The energy that they share is integral to genius loci of the piazza and the city. As such, a close examination of several local grassroots organization can reflect their will and vision for Favara.

\section{[2.2] Local Assets: Grassroots organizations}

In the late 2000s several grassroots organizations formed in the city of Favara, all with the similar intention of ameliorating their crumbling city centre. Operating on different levels, they aim to engage the community in various ways. Their strategies have proved to generate a shift in community involvement and most importantly, to rebuild the image of the historical centre. The following section highlights the grassroots organizations: Sicily Foundation, FARM Cultural Park and Associazione Culturale NICODEMO. 


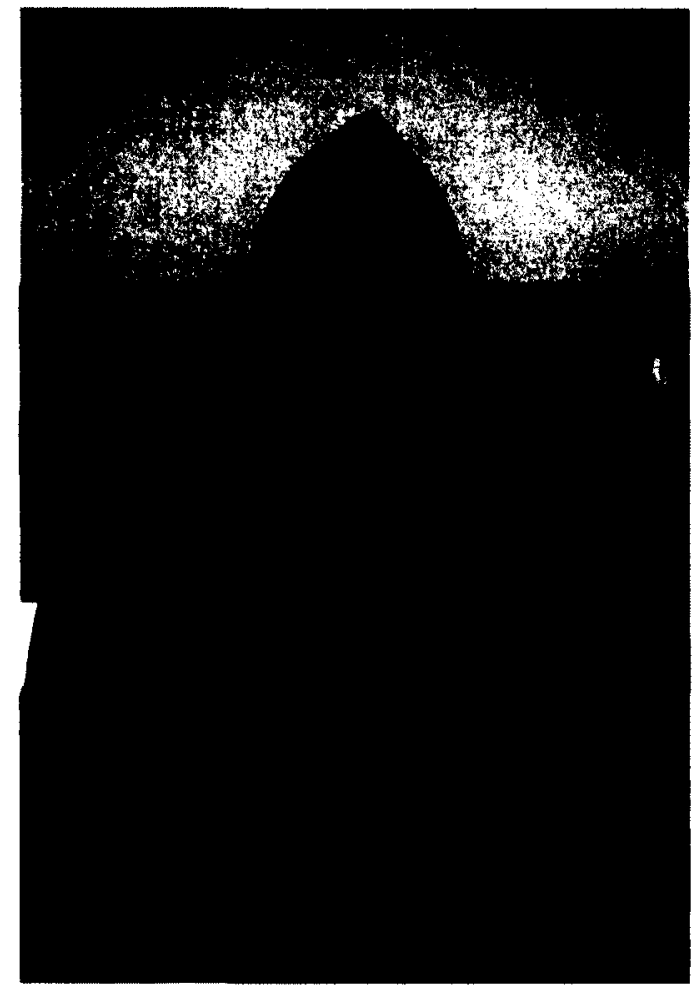

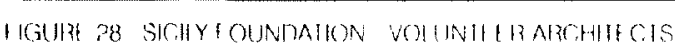

Sicily Foundation [SF] | Formed in 2008, this group of five Favara architects and engineers came together to protect historical properties and to ensure their structural integrity. Their mission is to establish a stable and safe historical city filled with people who can enjoy the social and cultural spaces that Favara could offer if it begins to invest in this area. Vicenzo Castelli, president of SF, explains that this requires a change in perspective and in attitude towards the historic centre. Namely, the locals must see the value of this area in order to appreciate it. He states that urban renewal cannot be approached in isolation; we must consider the social tissues. The historic centre must be better serviced so residents can live in a dignified manner and grow to respect their spaces. Castelli, a Favara native, chooses to live within the historical centre regardless of the social struggles the city has. He explained that the motivation for him to stay and revive Favara was far greater than the temptation to leave and make a life elsewhere'. Similarly, another member of SF, Michele Vitello, purchased a property in the historical centre where he now lives and has his architectural studio. Vitello stated that when he purchased his home over ten years ago people called him crazy. His dream of seeing the historical centre lived in and revived inspired Vitello to live there. He does not tire of guiding locals and foreigners through the historical city to show off Favara's architectural gems. ${ }^{2}$ The work of SF involves inspecting buildings and adjusting those that need repair in order to save them from the municipal wrecking ball. SF acquires abandoned buildings in the historical centre and renovates them into living spaces, thus adding habitable housing units to Favara's housing stock, rather than building new ones. They achieve this goal by identifying abandoned buildings that the city is prepared to destroy and then contacting property owners. In their experience, owners of these crumbling buildings are quick to let them go. SF has 'sold' several units through this process, though they make no profit. The space is practically 'given' to the prospective buyer by SF. The volunteers draw plans to restructure the space and file for permitting, free of charge. The client pays all permit and legal fees as well as the contractor to do the restoration work. 


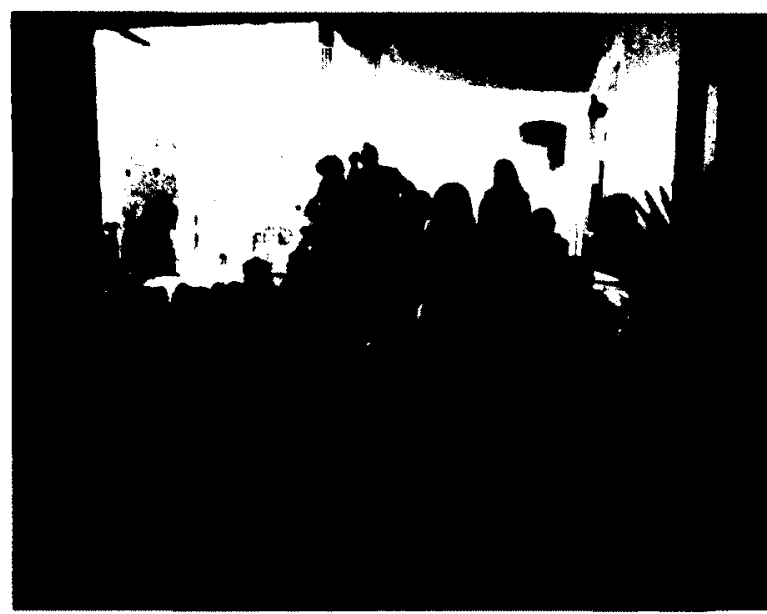

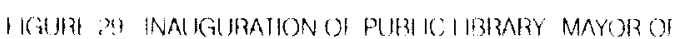

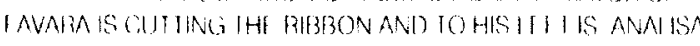

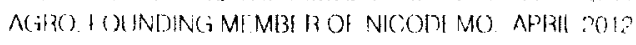

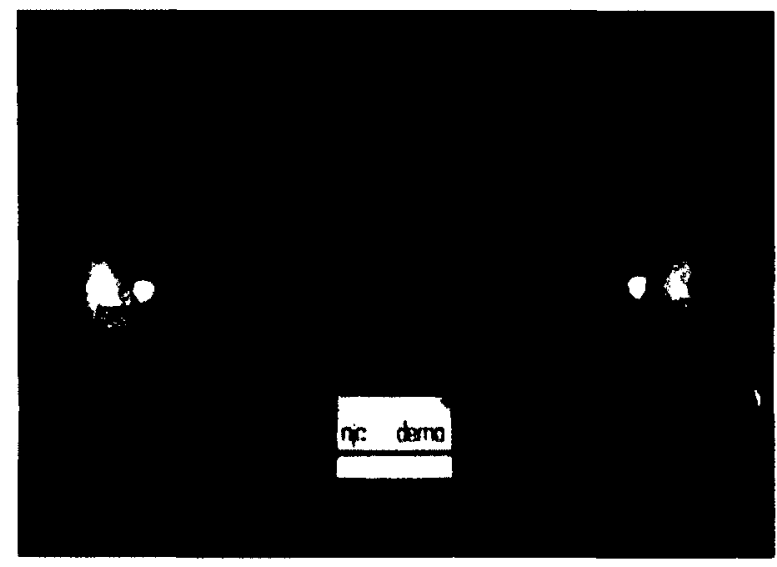

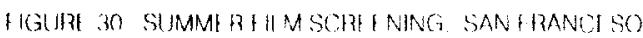

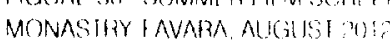

Associazione Culturale NICODEMO [ND] | Similar to SF, this organization formed by young Favaresi, between 25 and 35 years old, wish the city had more to offer its citizens. They formed the organization after returning to Favara following years of study in Palermo, Agrigento, Rome, and Sienna, and found the city had very little to offer in terms of cultural and social events. Their disillusionment with Favara, coupled with their deep roots and love for their city, motivated them to create the cultural association Nicodemo in 2009 with the intention to change the situation. The group organizes cultural events in the city ranging from an outdoor film series, musical and theatrical performances and photography and art exhibitions. They also sponsor artists in residence to visit the city of Favara. They publish a free press every other month highlighting upcoming events in the city and local interest pieces. The group has no headquarters or venue; the city is their stage and the piazza their office. They host their events in the historical city, such as theatrical performances in the old Castel at Piazza Cavour, summer films at the San Franciscan monastery, and host artist exhibits in vacant historical properties and at Sette Cortili (FARM Cultural Park's headquarters). Between May 2010 and December 2012 they had an extensive curriculum of close to 40 events. Ticketed events, such as the film series, are affordable; admission to a film includes an appetizer and a glass of wine for five euros. The organizers seek local sponsors year round in order to keep costs low and make it possible for more people to attend. Among their largest projects, Nicodemo advocated for the only public library, the historic Biblioteca Mendola, to be reopened and its volumes available to the Favaresi. The library has been closed for 20 years due to lack of funding, according to the municipality. It was a bittersweet success for Nicodemo as the library was reopened in April 2012, with an elaborate inauguration ceremony, only to be closed shortly thereafter. Despite this misfortune, the members of Nicodemo continue to mobilize throughout the city, seeking new opportunities that can ignite their city and offer its citizens a piece of their own culture. ${ }^{3}$ 

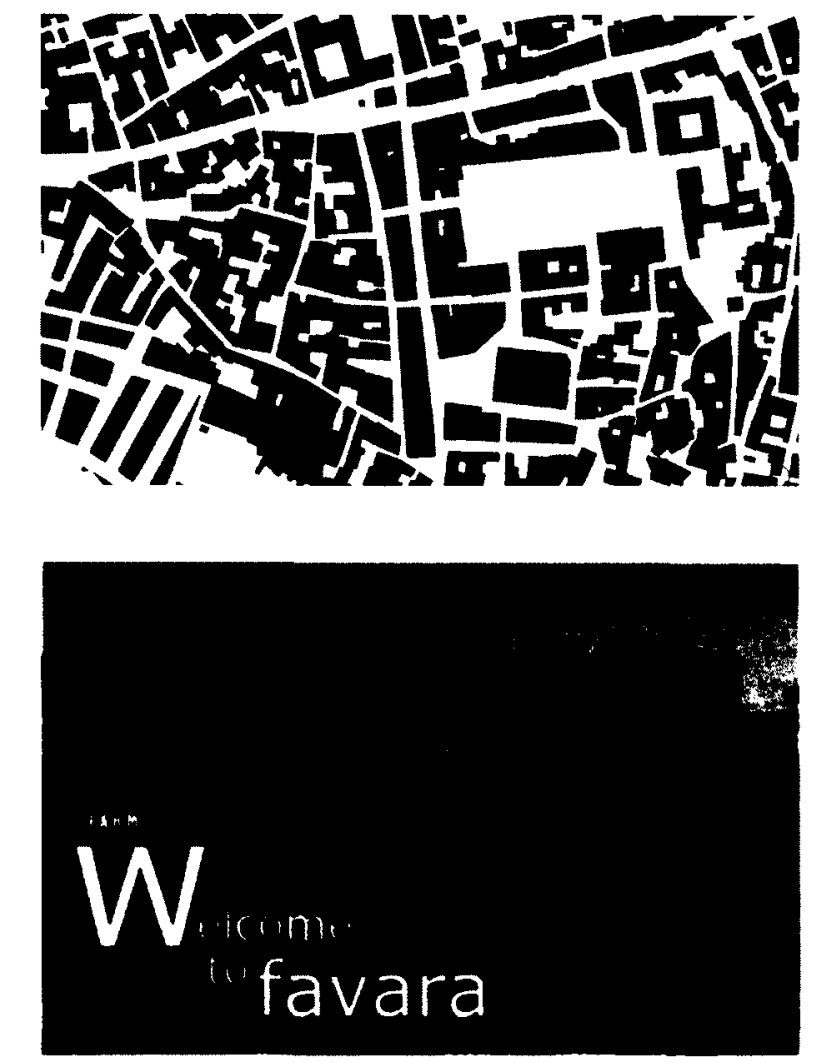

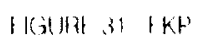

IOP PINK PHOPH RIIS OWNID BYIKP GRI L NIS I XISIING SH III CORIIII

MIDOMI HOUSL INSIOH SAt lit CORBIIIBH $10 \mathrm{OB}$ $\mathrm{KH}^{\prime}$

BOCHIOM SAMI HOUSL AI II HZFKPRP NOVAIION CIIRPRE NIIY ST RVESASA (G) ISHOP OHHOH AND ganitiar SPACI

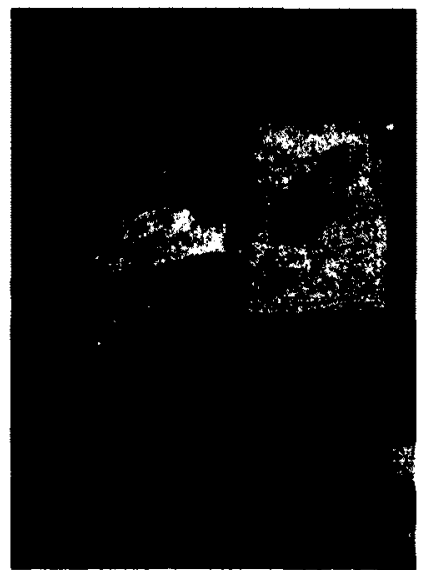

FARM Cultural Park [FKP] | Founded by a husband-and-wife team, Andrea Bartoli and Florinda Saeiva, the couple created the organization with the intention of making "a little part of the world better." Similar to Nicodemo, they decided to stop complaining about what Favara did not have in order to find a way to make it sparkle. Having a young family, they dream of taking their daughters to the historical centre but admit that there is little to do and it is not particularly attractive; abandoned buildings, boarded windows and desolate littered streets are a common sight in the historical city. The two are modern art aficionados who decided to take over a quasi-abandoned section of the historical centre called Sette Cortili. They renovated the spaces, created open galleries, film spaces and event venues. The team purchased a large portion of the historical centre and inaugurated the newly renovated spaces in June of 2010. Their master project is expansive, covering a large section of the historical city [see FKP map] and will include artist residencies, student residencies, a preschool, cultural centre and more gallery spaces. Currently, they have a bookstore and gift shop, sandwich shop, five gallery spaces, resto-dining hall, a community garden, architectural office and staff space, one artist residence and a champagne bar. For the past two years, FKP has celebrated its anniversary with a major party that takes over Sette Cortili. They invite artists, filmmakers, musicians, architects, designers and just about anyone they can attract to their event. The doors of their spaces are open every day of the week except Mondays. Armando Giglia, FKP employee, admits that FKP is not for everyone since most of the neighbours do not understand or enjoy modern art. However, he states that the residents of Sette Cortili take personal pride in the project. Giglia is pleased to be part of the FKP team and ready to redesign Favara ${ }^{4}$. The FKP website states that they are an urban, cultural, touristic park. Bartoli, explains that only by investing in their own backyards can they expect the city to change and potentially attract foreign investors to Favara. Bartoli is convinced that marketing Favara as a tourist location opens the city for more possibilities and economic growth. ${ }^{5}$ 


\section{HYPOTHESIS:}

LOCALS IN FAVARA ACT FOR THE COMMON GOOD OF THEIR CITY BECAUSE THEY ARE 'SOCIALIY ROOTED' TO THEIR CITY AND SOCIAL NETWOAKS.

WHAT DOES THIS LOOK LIKE?

FACETS OF SOCLL ROOTEDNESS
Members of the Sicily Foundation, Associazione Culturale NICODEMO and FARM Cultural Park share two things in common: first, they wish to change their city socially, culturally and economically. Secondly, they are all Favara natives, making it a personal battle to revive their city. Samatha Virone, a founding member of Associazione Culturale NICODEMO, states "it's a bad habit to love this place" (Barina 2011), yet this very notion motivates members from all groups. Being of a place and identifying it as home proves to be a strong element which roots them and keeps them in Favara. Building from this finding, the following section of the research will attempt to rationalize their collective behaviour, as well as define key concepts to describe their sense of rootedness. The concept of social rootedness is a term borrowed from the social sciences and will be outlined through community, attachment, identity (self and group), sense of place and belonging. The intention is to reveal how these concepts have generated community action which laid the foundation for reigniting the cultural and social spaces of Favara's abandoned city centre. 
THE LOCALS OF FAVARA ACT COUECTIVELY BECAUSE THEY ALI SHARE THE SAME INTEREST: FAVARA!

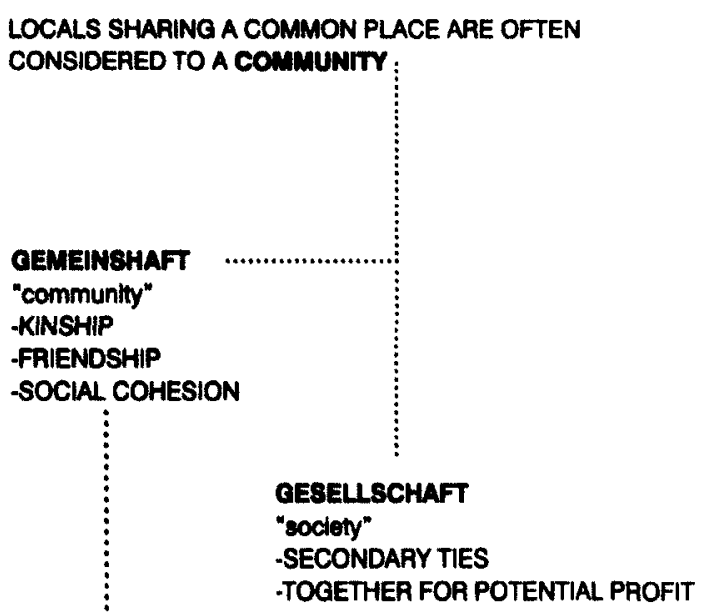

ATrACHMENT

TO A SOCIAL ENVIAONMENT

TO A NATURAL ENVIRONMENT

\section{[2.3] The Roots of Collective Action: A Composition of Social Rootedness}

According to Marwell and Oliver (Critical Mass in Collective Action, A Micro Social Theory, 1993) collective action is defined as action taken by two or more people in pursuit of the same collective good. Individuals in a group are characterized by their interest in the collective good and the resources they have to contribute towards it (18). Therefore, before collective action occurs, interest must exist. In the case of the city of Favara, the shared interest among the socially driven locals is Favara. Their interest is demonstrated in their sense of belonging and attachment, which has generated the already mentioned grassroots organizations.

Communitas | The concept of community derives from the Latin word communitas, composed of the words, cum, meaning "with/together" and munus, meaning "gift." it should be noted that it is a constructed concept borrowed from the work of Ferdinand Tönnies' Gemeinshaft and Gesellschaft (1957). Gemeinshaft, translated as community, refers to a group typically formed through kinship and friendship, perceived as a cohesive social entity in which its members dwell together and organize a common life. On the other hand, Gesellschaft, translated as society, describes a grouping of people together because of potential profit or personal gain, such as labour and work unions. It emphasizes secondary relationships rather than family. Cities today reflect elements of the Gesellschaft in their organization and functioning, yet the belief in a Gemeinschaft- community- has not faded within society and is seen in the city of Favara. People continue to believe in the notion of community, either as ideal or reality in which people can operate collectively for a collective benefit (Cohen 1985, 8). Community has been defined as 'the experience of Gemeinschaft,' a 'we feeling', the sense of collective identity and a feeling of natural belonging.' The idea of community serves as a point of departure when investigating "rootedness, cohesion and belonging." (Little 2002, 7).

Attachment | Attachment can be studied with respect to social and natural environments. As researched by human geographers, people react positively to a specific setting in which they feel a sense of belonging. Attachments to place materialize as groups come together through common symbols in language and place (Brehm 2007, 478). Others have argued that the relationship between community and place is sufficiently influential that each will reinforce the identity of the other (Relph 1976, 34). In addition, the familiarity of knowing and being known in a particular place forms roots to a place, 


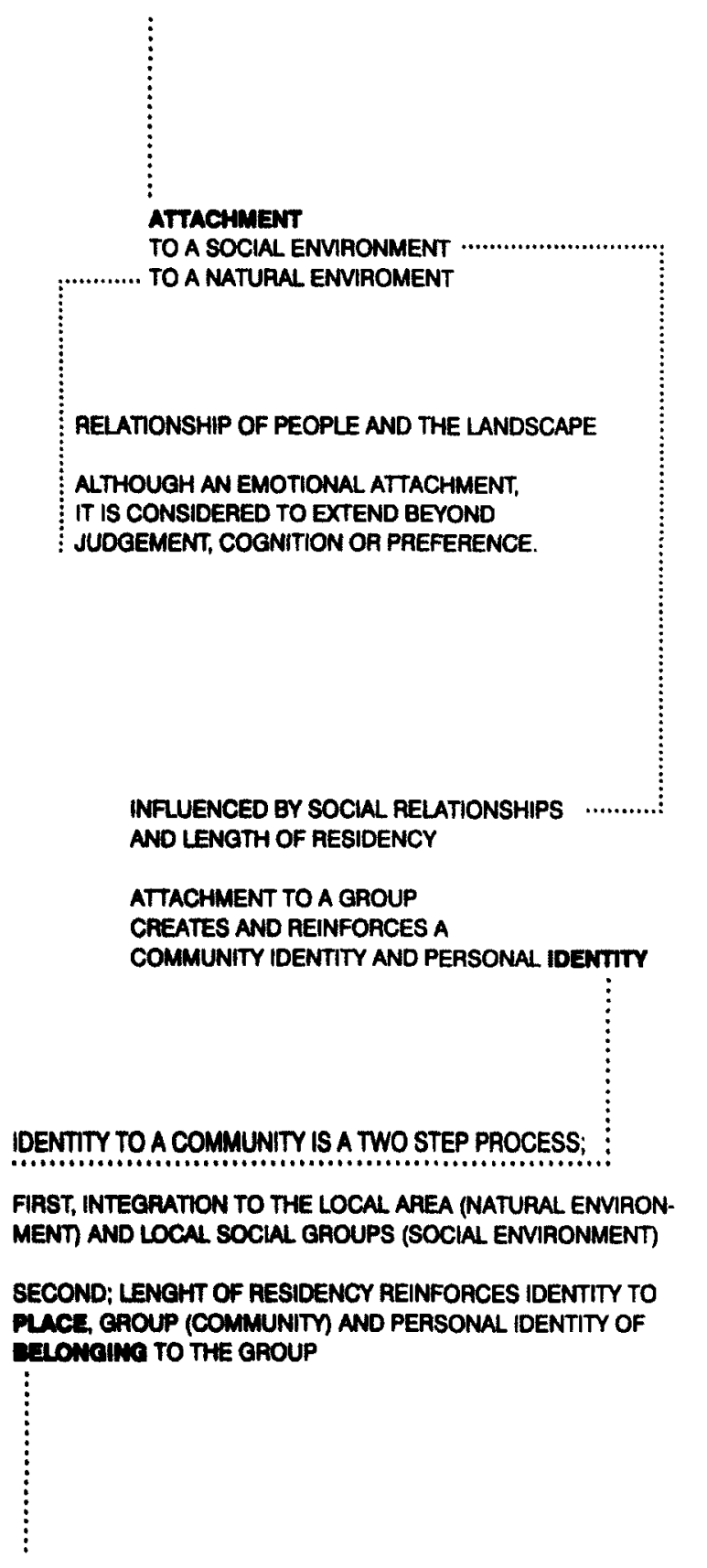

which in turn develops a sense of care and concern for that place (Relph 1976, 37). In a study by Kasard and Janowitz in $1974^{8}$, the pair found that community is a system of kinship and friendship ties that can be formal or informal and that length of residence does in fact influence community attachment. Therefore, attachment to a community is fundamentally rooted in family life and socialization. Natural Attachment, as defined by Robert. B. Riley, is an affective relationship between people and the landscape that goes beyond cognition, preference or judgment (Riley 1992, 13). Studies in attachment to a natural community offer similar results as those above and reveal that the natural environment is a necessary component of community attachment, which draws individuals closer to their community. In a recent study by Brehm (2007), through qualitative data and interviews, attachment to the natural environment revealed to be a contributory factor in community attachment. Many of the participants described a notion of "rootedness," related to an emotional connection for the natural environment. The study also found a strong correlation between attachment and length of residence (Brehm 2007, 483-4). Attachment to place plays an important role in the connection with a community because it goes beyond a personal belief and encompasses the beliefs of the whole group. As a result, it begins to generate an identity. An individual begins to simultaneously create a personal identity and a group identity, making both concepts important in community attachment (Cheng 2003, 94).

Identity | Studies in community identity have revealed that communities can become imprinted with public meanings that reflect symbolic and cultural identities for a group and individuals. Many of these studies use biographical data of memories to a place and the evolution of these, which reveal a symbolic extension of the self via a constructed identity. ${ }^{9}$ The process of identity through community attachment is said to be two-fold: first, an individual integrates within a local area through local social groups, for example. In this phase, studies consistently reveal sentimental ties to a specific place ${ }^{10}$. The second phase is length of residency that has been found to be a secondary factor in reinforcing place identity, specifically in developing a sentimental attachment to place and a sense of home (Cuba 1993, 115). Place-based meanings are expressions of a personal identity, as well as a social group identity. In adopting a group identity, an individual communicates with the group that their intentions and behaviours are in line with that of the community. 


\section{PLACE IDENTITY OR SENBE OF PLACE:}

INTERELATED TO ATTACHMENT, COMMUNITY \& IDENTITY PERSONAL AND SUBJECTIVE

\section{SENSE OF PLACE IS ASSOCIATED WITH THE} NATURAL ENVIROMENT.

A PERSON'S PERCEPTION AND REACTION TO THEIR ENVIRONMENT OCCURS SIMULTANEOUSLY, ALLOWING THEM TO GENERATE A SENSE OF PLACE AND

Belonaina

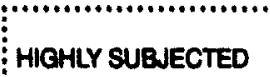

BASED ON PERSONAL PERCEPTION

"a senes of exporiones, phenomenology of

locallity whioh serves to create, mould and reflect

porcekwed ldeals surrounding plece"

Belonging and Locality (1998) Lovell, pg 1

recell- HYPOTHESIS:

LOCALS IN FAVARA ACT FOR THE COMMON GOOD

OF THEIA CITY BECAUSE THEY ARE

......'BOCIALYY ROOTED' TO THEIR CITY AND

SOCIAL NETWORKS

SOCLLL ROOTLDNESS PROVED TO ENCOMPASS

CONCEPTS OF COMMUNITY, ATTACHMENT,

IDENTITY, PLACE AND BELONGING.

THE LOCALS EELONGING TO SICILY FOUNDATION,

NICODENO AMO FARM CULTURAL PARK SHAAE THESE

TRNTS AND CAN BE DESCRIBED AS SOCWLIY ROOTED

TO FAVARA. THEIA ROOTS TO THEIR PLACE MOTIVATE

THEM TO ACT AND GENERATES CHANGE THEYAREAN

ESSENTUL TOOL IN RECONNECTING THE COMMUNITY.
Sense of Place | Embedded within the perceptions and sentiments of identity is the construct for sense of place. It is difficult to refer to it as a concept because it does not present itself in isolation; it is deeply entangled with theories of attachment, identity and community. It is a multidimensional idea that encompasses all of the previously mentioned elements simultaneously. Sense of place can be referred to as a personal and subjective perception of an individual's local environment. It is considered to be dual in nature because it is both an interpretive perspective, as well as a reaction to a local environment (Irwin 1992, 262). In a study conducted by D. Hummon (1990), findings revealed that sense of place could take two forms of rootedness: everyday rootedness and ideological rootedness. In the first form, individuals do not consciously identify with their community. In fact, their sense of attachment to place is described very simply, primarily composed through biographical data and images of community life. In the second form, ideological rootedness, individuals demonstrated strong feelings of satisfaction, attachment, home and a sense of identity (Irwin 1992, 263-70).

Belonging / Similar to the previous term, belonging can be difficult to pinpoint as it is also based on personal perception, which is highly subjective. Belonging is defined as "a sense of experience, a phenomenology of locality which serves to create, mould, and reflect perceived ideals surrounding place." "It is considered as a form of remembering. since memories of belonging to place are instrumental in generating a collective memory and identity and tie social relationships to a location. Belonging can evoke sentiments of longing to a particular location. Emotional triggers caused by locality further emphasize a sense of social belonging and allow for the imprinting of memories to a place. ${ }^{12}$ Belonging is a powerful indicator of community attachment to place and social locale.

Outlining key terms that encompass Social Rootedness reveals intricate relationships and dependencies between concepts. This suggests that all of the above mentioned terms play a role in the framework of social rootedness. The value of this framework is demonstrated in the formation of community, attachment as a result of and/or because of an identity to a place or group which allows a person to feel a sense of belonging. The entire process, though not linear, strengthens community values and goals and is a tool for social cohesion which can ignite community integration and change. Favara's local volunteers embody this social phenomenon and reflect a spirit of Favara that has been lost in the physical composition of the city. Their volition and energy towards the city is the genius locus, what is needed is a proper way to concretize this through building 


\section{[2.4] Case Studies}

Formulating a design strategy that could capture the genius locus of locals and strengthen the identity of Piazza Cavour in order to connect it to the city again requires examples from which it can aspire. In reviewing literature regarding the value, design and revival of urban space, the work of Jane Jacobs inevitably comes to the forefront. Jacobs was a journalist and author, considered an urban-activist famous for her book The Life and Death of Great American Cities (1961). Originally based in New York, she spoke out against urban planning policies that were set out to destroy old neighbourhoods such as Washington Square (Max 2011, 69). She promoted the rich culture and micro social governing systems* within established neighbourhoods and fought to keep Greenwich Village in New York from being "slum cleared" for new development. She moved her voice and opinions to Toronto, Canada in 1968 and played a pivotal role in protecting much of the city from being divided in half by the Spadina Expressway proposal which would have also destroyed many established Toronto neighbourhoods (Max 2011, 1249). In her work as an urban activist and within her book, she advocates for the life in a city; contained within neighbourhoods life is in its streets, people and public spaces. From her text I wish to highlight a few points which guide the design proposal.

First, the automobile is typically blamed as the culprit for the death of cities and/or under usage of streets, sidewalks and public spaces. However, Jacobs stresses that each city has much larger economic and social concerns to address and these should be the primary focus. Only with a close understanding of how a city operates it is possible to remedy social conditions before simply extracting the automobile (Jacobs 1961, 7). Secondly, she emphasizes the street as the vital organs in city. More than just infrastructure on which cars travel, the quality of streets and its sidewalks can identify a city as interesting or dull. This is due to the quality of the building fronts that delineate a street. A variety and density of shops, as well as places to stop, sit, and watch city activities unfold are all necessary elements of a safe and vibrant city (Jacobs 1961, 29-37).

The influence of Jacob's work is valid and continues to influence planners, architects, designers and policy makers today. In addition to Jacob's work, I have also chosen to focus on the work and research by architect Jan Gehl. His passion for designing at a human dimension addresses the liveliness of streets and public spaces. 


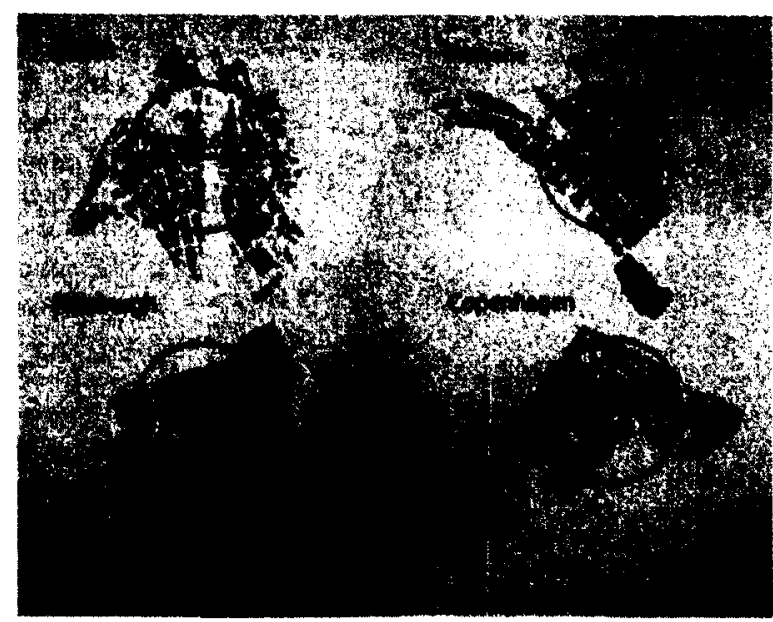

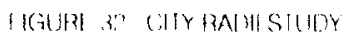

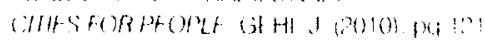

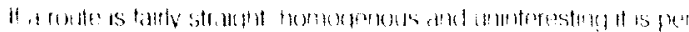

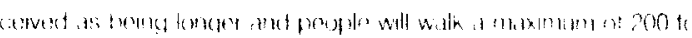
$3(1+1)$

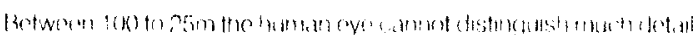

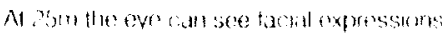

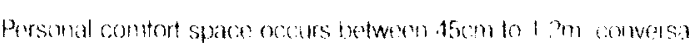

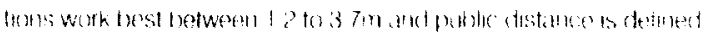

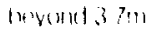

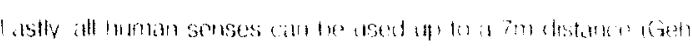
(i) 13
Gehl is a Danish architect and professor in Copenhagen, Denmark. He has published several books; Life Between Buildings (1971), New City Spaces (2006) and Cities for People (2010) as well as other publications. His research focus and architectural work are centered on the human use of public spaces. Gehl continuously advocates for the 'space between buildings', that is, urban social spaces found in streets and squares. $\mathrm{He}$ states that modernism placed a low priority on public space, robbing the city of its traditional function as the social forum for city dwellers. (Gehl 2010,5). Gehl states that the $21^{\text {st }}$ century has proved to reawaken to a human dimension with the emphasis of achieving lively, healthy and sustainable cities which historically where cities have functioned with the city dweller as a pedestrian. He specifies Venice, Italy; its particular geography did not allow for car travel. The city functions as it did when it was established: as a vibrant, healthy and wealthy city. Though it presents a great case for pedestrianism, Venice cannot be replicated and that is not the reason Gehl highlights the city. Instead, he wishes to point out that improving the conditions for pedestrian traffic can lead to new patterns and increased life in city spaces. Drawing on survey data from Melbourne and Copenhagen (both which adopted pedestrian plans for their main downtown streets) this connection is clearly documented (Gehl 2010, 16). Furthermore, Gehl states that this finding is valid and transferable to cities of various cultures, climates and economic and social conditions. Whether people choose to walk or not are dependent on the careful planning details that address the human dimension. These are the quality of streets, sidewalks, squares and in presenting a tempting invitation. Based on Gehl's research, he outlines several dimensions for comfortable and successful space planning. First, he states that most people are willing to walk $500 \mathrm{~m}$ to $1 \mathrm{~km}$ in a city, provided the route is interesting, has visual variety and quality. Secondly, he reveals the 'magic' proportion of most cities: the 'downtown' or central core must have a walking radius of no more than $1 \mathrm{~km}$. Even within larger cities such as London and New York, their downtowns are divided into districts and sub-centres having a $1 \mathrm{~km}$ radius. Hence, the maximum acceptable walking distance is $1 \mathrm{~km}$ (Gehl 2010,121). Gehl also provides smaller dimensions to be considered within the design of open spaces. The philosophies of Jacobs and Gehl support the framework of this study. In addition to this, Copenhagen, Denmark, and Agrigento, Sicily will be examined as examples from which the city of Favara can aspire. Copenhagen is chosen because it models the ideal for a vibrant, lively and walkable city. In the Foreward for New City Spaces, Richard Rogers describes Copenhagen as a "beacon of hope for urban regeneration," a true example of a humanized European city from which all cities can learn." 


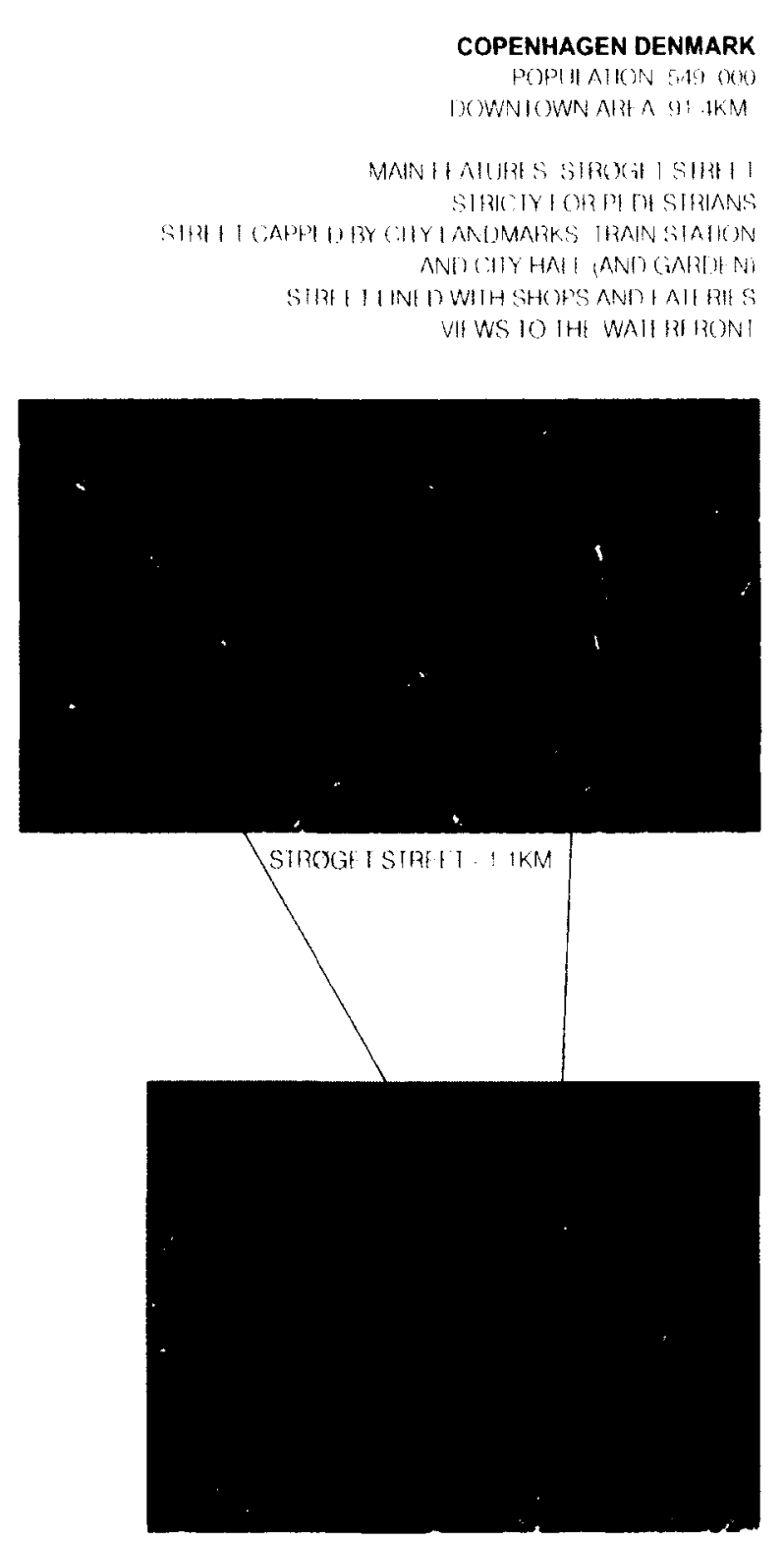

HEUHP 33 MAPS OI LOFI NHAG N DI NMAKK

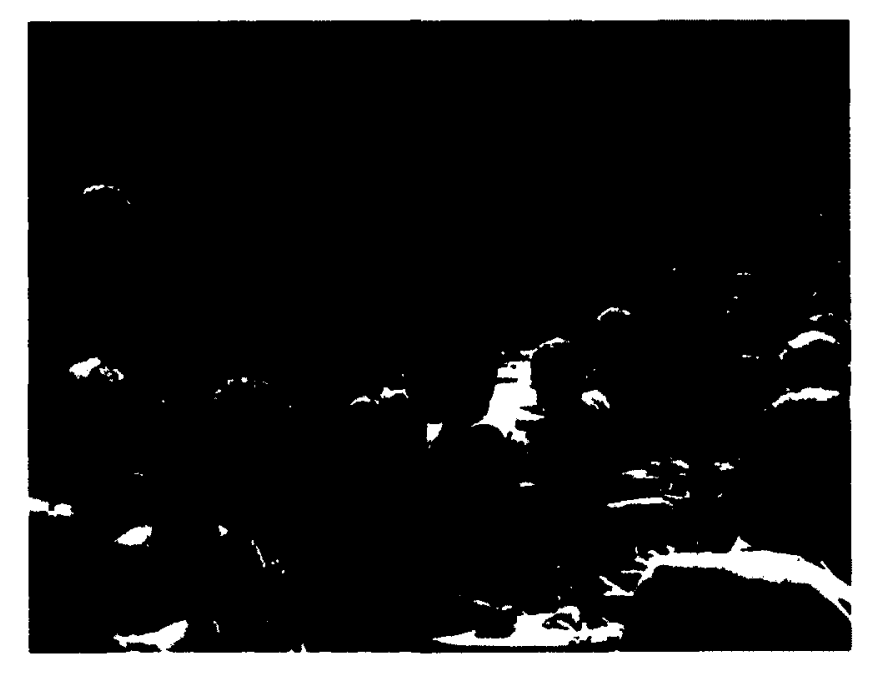

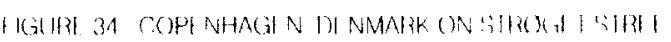
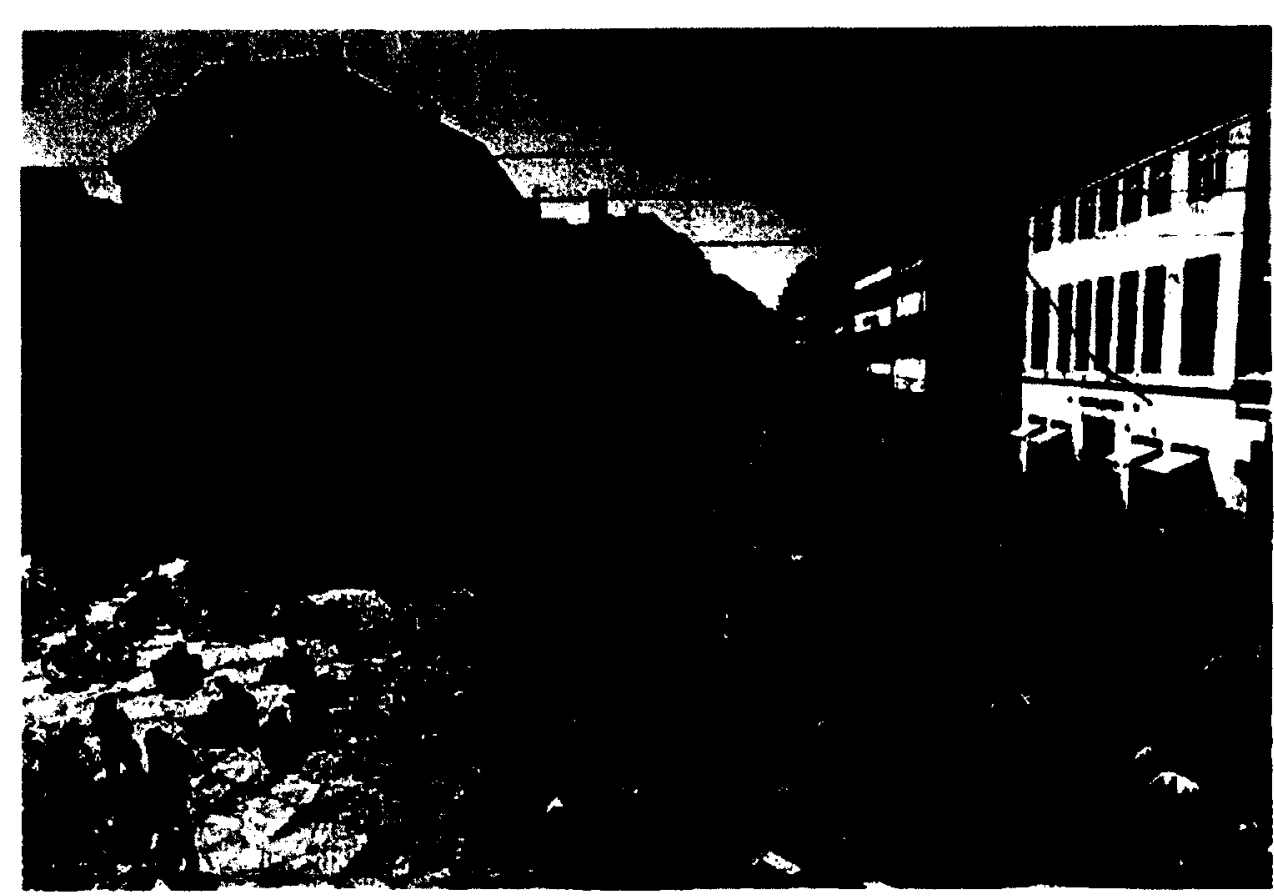

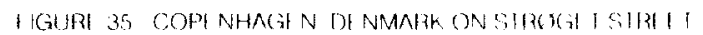



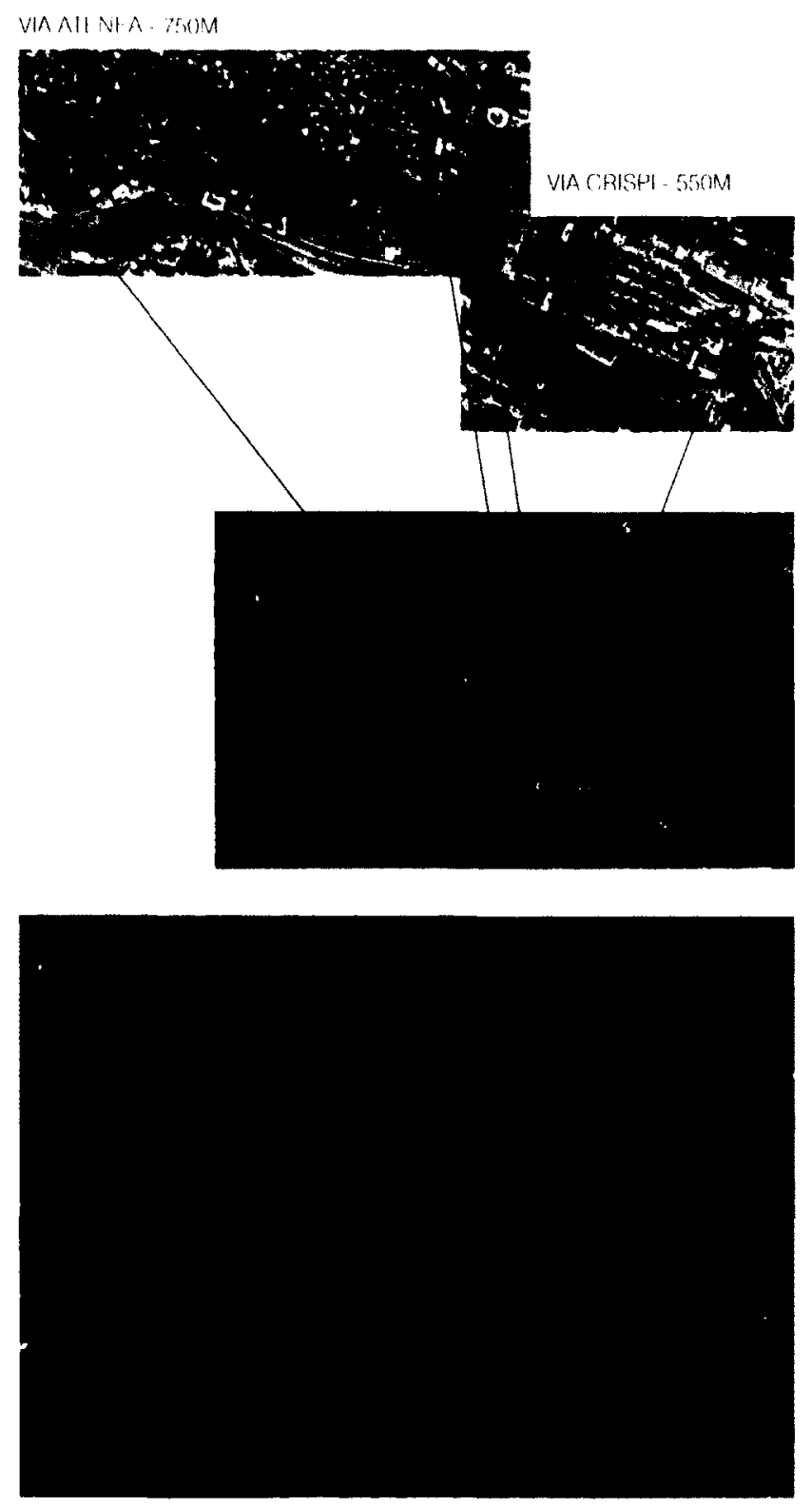

IIGURA 36 MAP OH WI SH RAN SICHY RE GION OF AGRIGH NIO
Agrigento, on the other hand, offers a more local and culturally specific example. It is the neighbouring town to Favara which already attracts its local residents. Though it is larger and its population surpasses Favara's, both are hilltop inland towns and share many of the similar social issues already presented.

\section{AGRIGENTO SICILY}

POPUII AIION 59 :O0

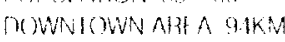

MAIN FEATURES: VIAATENEA

CAPPH DRY GIY IANDMARKS MUNICIPA

IHI AIRE WIIH HIAZZA AND GARBDI N

SIIHWAIKS SIOPH I RONI SHOPS AND

AII RII S

MAIN FEATURES: VIA CRISPI

IBIT IINTD BOH III VARD WHH WIDI

SHOH WAIKS AND B NCHFS

SMAII PIAZZA BII IWI I N PII NTYOH

PAIT RII SAND SHOPS

VIIWS $10 \mathrm{IHH}$ OCHAN

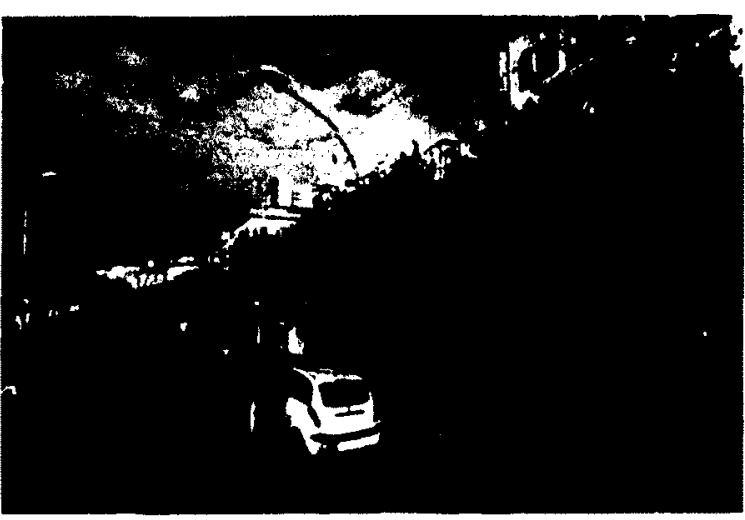

IIGUMI 37 AIONGIVIACRISPI

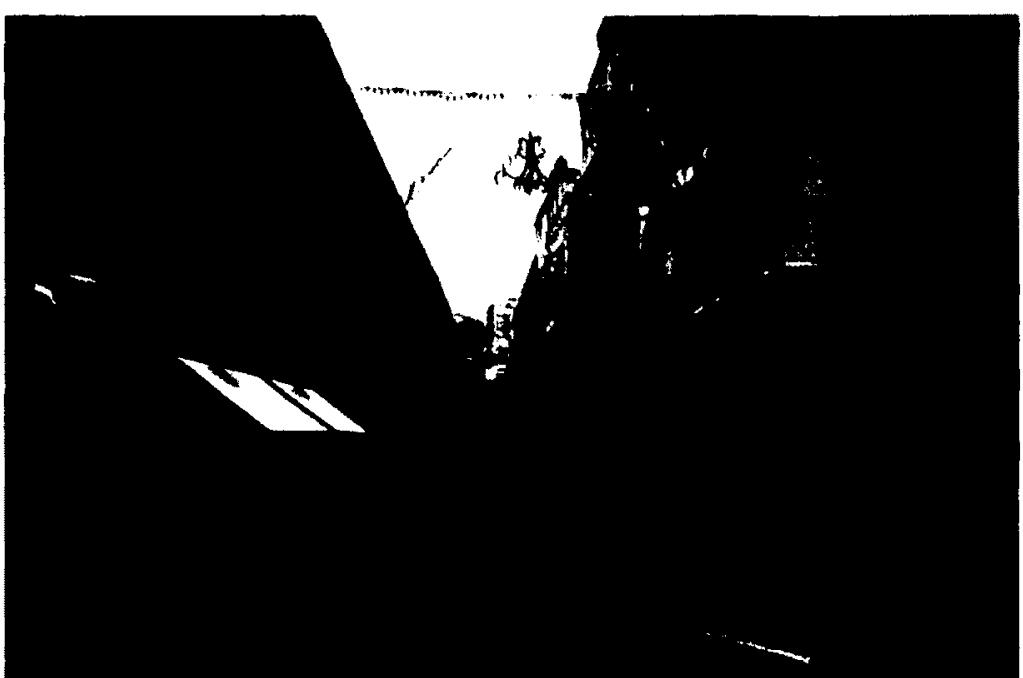

HKSLHZ 38 VIAAII NIA. AOBRIGI NIO 
O.R.T.U.S. IOPERAZIONE DI RIOUALIFICAZIONE TERRITORIALE URBANA E SOCIALE, TRANSLATED AS URBAN, SOCIAL AND LANDSCAPE RENEWAL TASKFORCE']

IORTO MEANS GARDEN IN ITALIAN. THIS GREEN VALLEY WAS ONCE A MAJOR FARMING AREA. THOUGH A FEW SMALL SCALE FARMERS REMAIN.]
Finally, it would be unjust to not mention a recent urban scale project in Favara called O.R.T.U.S. completed in June 2011 and commissioned by the municipality. The project aims to reclaim the green area east of Piazza Cavour and offer pedestrian and bike opportunities. The lead architect, Giacomo Sorce, outlined that the intention of the project was to entice more pedestrians to move through the city; specifically from the largest green area in the city, the old Orto, to the newly designed Piazza della Liberta and towards the existing 'Largo Canale Fontana' and newly designed piazza. Historically, the Favaresi accessed water at two public city wells. The well at Piazza Giglia was covered up in the mid-1980s and is now a landscape of uninhabited concrete and stairs at the corner of two major roadways. The well at Largo Canale remained opened but was used as a parking lot and a car wash station. ${ }^{13}$

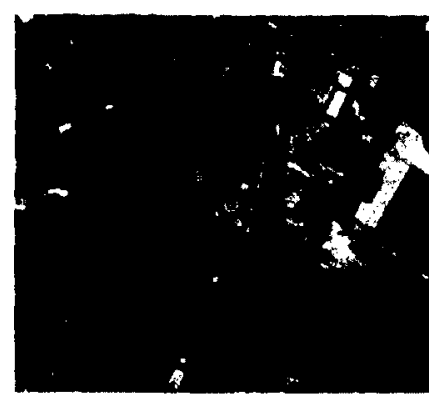

PIAZZA GIGLIA

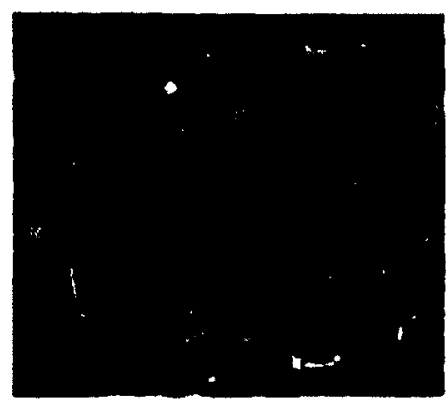

LARGO CANALE

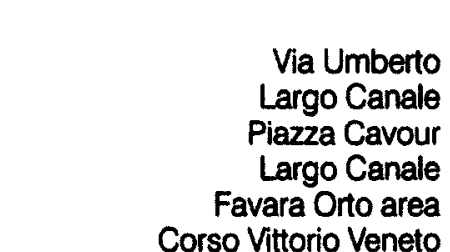

FIGURE 39

1.AERIAL PHOTO OF FAVARA

2 AERIAL VIEW OF PIAZZA GIGLIA

3. AERIAL VIEW AT LARGO CANALE

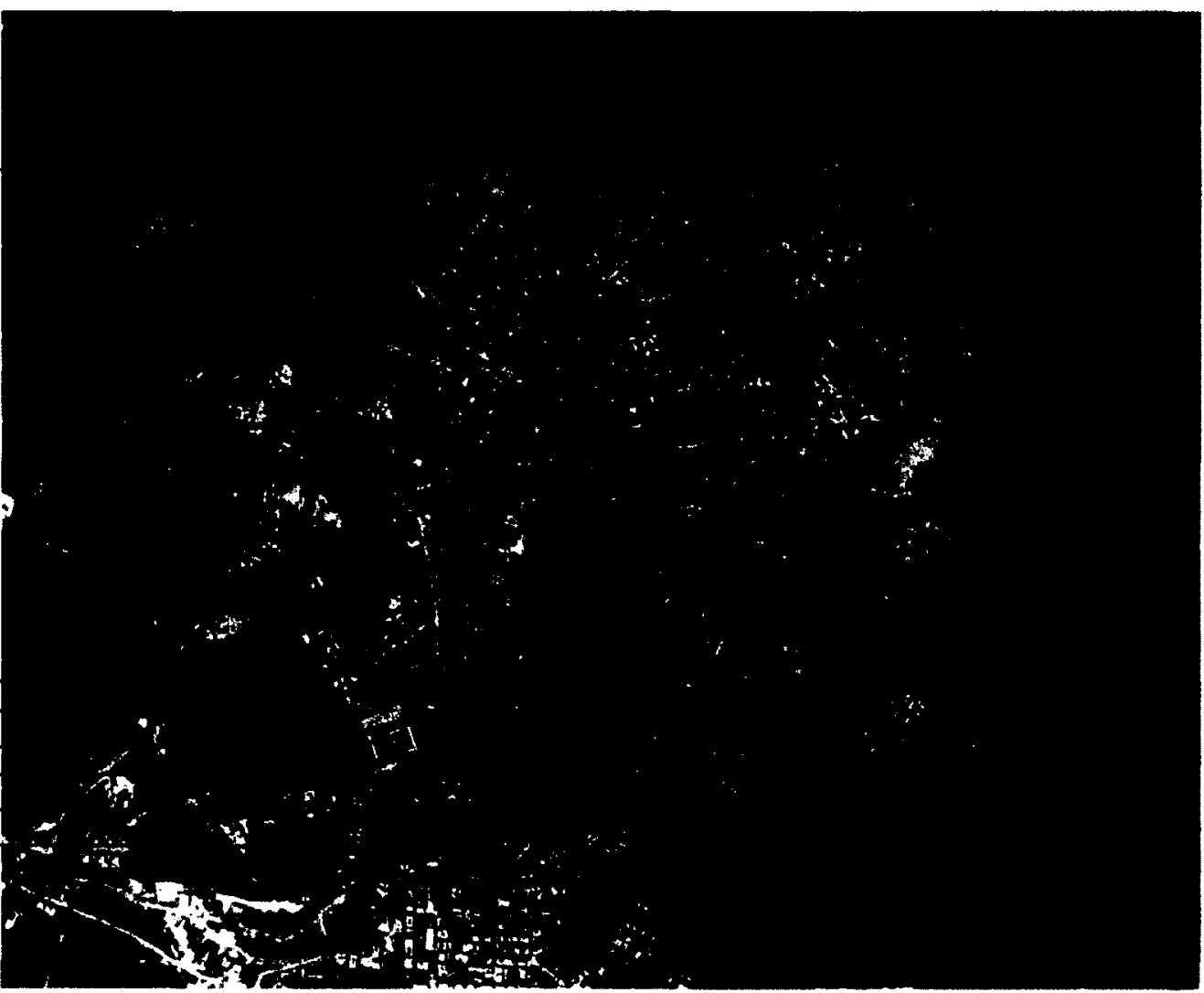



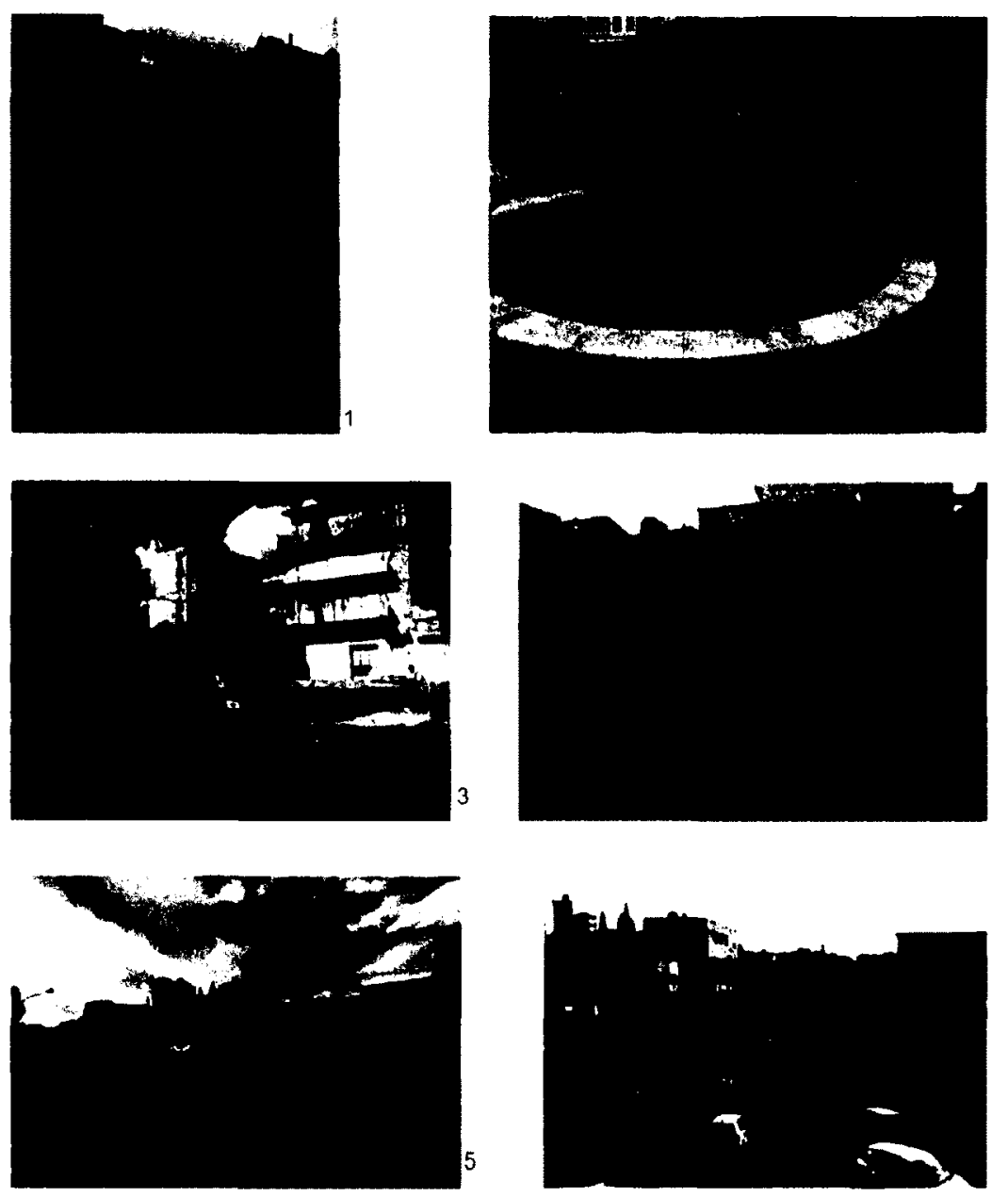

The O.R.T.U.S project did something right in maintaining the water source open and available at Largo Canale. However, the design of the piazza is no different from before. It continues to be a large open well, now with banister that prevents a person from falling in, placed on a concrete pad. The potential for the well to have been a fountain or water focal point was missed since water does not move up, out or splash. Besides the addition of a few sitting spaces, the new piazza offers no shade as there are no trees. It resembles the mid-80s design of Piazza Giglia which is also a concrete stage with no trees that merely occupies space between two roads.

The redesign for Piazza della Libertà, also within the scope of O.R.T.U.S, addressed the busy road intersection where Via Umberto descends from the historic centre and meets Corso Vittorio Veneto. Although it is referred to as a piazza, this space offers little appeal to sit or stay. The new design features a clean wall with cut-out openings towards the historic centre. In defining a sidewalk in front of the new wall, the previously open area, where many local vendors used to sell their produce, was reduced in size and pushed these farmers away. They now sell along Corso Veneto and pitch a tent on the road for the day while others arrive at dusk in the summer months and place their merchandise along the roadside. From old photos of the area, it seems the space was more successful when it was open since commercial activity can offer opportunities for people to socialize. Today this space has no program [nor is it flexible], no benches or shade and is another junction at roadways.

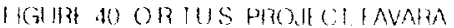

IHE WIII AIIARGOOCANAI LRE POHII

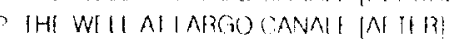

3 EXISIING SPACI AIIARGOC CANAI

4 NI W PIALLAI ARGOCOANAI

5 PIAZZA DOHIIA IIBI RIA HBHIIOHE

6) PIAZZA DHIAIBI BIA IAN UE B:
} 


\section{ENDNOTES}

1. Reler to Appendix A for full interview comments by Vicenzo Castelli

2. Refer to Appendix A for full intenview comments by Michele Vitello

3. Refer to Appendix A for full interview comments by NICODEMO members Nadia Castronovo and Carmelo Nicotra. Also based on conversations with NICODEMO members Filippo Bosco. Simone Castellana, Nadia Castellana and Rosana Ario and Analisa Agro

4. Refer to Appendix A for full interview comments by Armando Giglia.

5. Refer to Appendix A for full interview comments by Andrea Baroli and Florinda Saieva.

6. http://en. wikipedia.org/wiki/Community

7. From (Naisey 2007, 852), references definitions and terms of measurement within community studies, specifically the work of Bender 1978; Kanter 1972; Keller 2003. Who use the terms "experience of Gemeinschaft", "we feeling" and collective identity, respectively.

\section{8. (Kasarda 1974)}

9. Within Chapter 8 of Place Attachment; by Hummon D. "Community Attachment, Local Sentiment and Sense of Place", reference is made to studies by Cochrane (1987) Rowles (1983) Suttles (1984) For bibliographical reference of these studies, refer to pp 276-77.

10. Cuba, Lee and Hummon, M. David in "A Place to Call Home: Identification with Dwelling, Community and Region" site the following studies; Gerson of al. 1977; Goudy 1982; Guest and Lee 1983: Hunter 1974: Kasarda and Janowitz 1974: St John, Austin and Baba 1986. Rowles 1983

11. Locality and Bolonging, $\theta$ d. Lovell, N. 1998. Lovell cites (Schama 1995. Tilley 1994), pg 1

12. Locality and Belonging, ed. Lovell, N, 1998. Lovell makes reference the work by (Lyon and Barbalet 1994). pg 6.

13. In convereation with Giecomo Sorce and based on historical photos and map from (Sciara 1997, 89)
The intention of addressing water usage, green space and walkability in this area is commendable and definitely enriching for the city of Favara. However, the O.R.T.U.S project offered new design for piazza spaces but did not address the network of roads and sidewalks which takes a pedestrian there. The areas targeted are along Corso Vittorio Veneto, where sidewalks disappear at times and there are no stop signs or traffic controls. As a pedestrian, it is uncomfortable and sometimes unsafe. Furthermore, the O.R.T.U.S project does not entice a person to walk between the newly created spaces nor linger at these new piazzas. The objective is valid and necessary for the city, but O.R.T.U.S is poorly located, does not address a human scale and the overall scheme does not penetrate the historical centre.

This chapter examined the significance of genius loci by recognizing the role that location and character play in buildings and cities. Norberg-Schultz points out that a hole was left by modernity and modern architecture; where free flowing spaces contained in clear boxes only confused and denied the essence of dwelling (Norberg-Schulz 1979, 195). His book was published in 1979 and the gaps left by modernity are still waiting to be filled. In adopting his argument, a revival in the value of genius loci is implied. His argument is valid today and has provided a starting point in examining the city of Favara. The genius locus of Favara is embodied in its locals; they carry the city's past and future. Their shared interest in the city is what draws them together to collaborate for the community of the city of Favara. Outlining the elements that encompass community exposed several terms which together composed the framework of Social Rootedness. The significance of being attached and socially rooted proved to strengthen their community values and prospective future. Thus, socially rooted locals are tools of social cohesion and can ignite community integration. They are powerful tools of change within cities today and reflect the genius loci of a place. In considering an urban design intervention for Favara's historical city, beginning at Piazza Cavour, the work of Jane Jacobs and Jan Gehl provided valuable lessons and inspiration. Their approaches to urban design revealed a similar interest in human scale design, beginning at a street level in order to enliven public social spaces. Lastly, an examination of Copenhagen, Denmark, and Agrigento, Sicily, offered streetscapes and dimensions that can be transferable for the design proposal. 


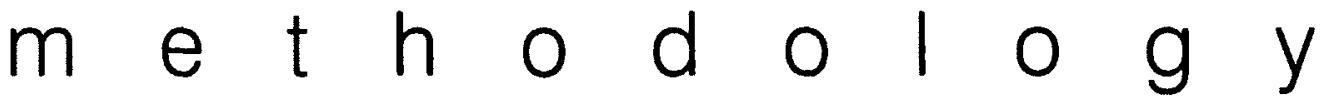

\section{[3] METHODS: FIELDWORK \& SITE ANALYSIS}

The determination to revive Favara, demonstrated by the work of the grassroots organizations was the inspiration and point of departure for this thesis. Daniele Pario Perra', a professor with the Directed Studies Abroad program for Carleton University in Bologna, discussed with me the opportunity to participate with citizens who were restoring old spaces and rebuilding their community in the city of Favara. My research question was developed from the collective actions of the grassroots organizations that were deeply embedded in their social network and connected to their location, the historical centre of Favara. I came to refer to this as being socially rooted and my intent was to expose this behaviour as a necessary element in community regeneration.

This study uses a mixed-methods approach within a qualitative research model; a short term residency in Favara, interviews with local residents, city analysis of social and public spaces, and a site visit with a survey period. These various methods provided me with a thorough knowledge of the key figures in the city, a personal experience of current urban issues, the local sentiment Favaresi share for the historical centre and an understanding of urban movement and social spaces in the city. This study was done in phases, which were designed and completed with the intent of targeting the social roots and layers of urban decay in order to propose an appropriate architectural-urban strategy. This chapter will discuss each phase and how data was obtained.

\section{[3.1] PHASE ONE - FAVARA RESIDENCY AND INTERVIEWS}

Phase L-Residency | Using a qualitative design research and following an anthological stance, I relocated to Favara and liveD within the historical city in order to fully grasp how this community was rebuilding itself. I was hosted by FKP as an artist-in-residence and in exchange for housing I helped the organization with various tasks. Being fluent in Italian facilitated my residency and work while in living there. My time there allowed me to be knowledgeable regarding the key figures to be interviewed and the questions to ask. 
The following individuals were intenviewed:

SF members: Vicenzo Castelli (founder and president), Michele Vitello (member)

FKP team: Andrea Bartoli \& Florinda Saeiva (founders), Armando Giglia (employee)

NICODEMO members: Nadia Castronovo (member), Carmelo Nicolra (member)

Several of their comments are included in section [2.2] Local Assets: Community Networks. For full length interviews refer to the Appendix.
[Interviews] During my residency in Favara (June - August 2012) I conducted several interviews with key participants of Sicily Foundation (SF), FARM Cultural Park and NICODEMO. I chose these organizations because I learned they were the largest and most prominent in generating events and promoting changes in Favara. I wish to note that SF has four other members but I chose Vicenzo Castelli because he was the founder and Michele Vitello because he lives and works in the historic centre. I was unable to meet the other four members of this organization. On a similar note, FKP team has two other full time employees who were not interviewed. This is because one of them does all the maintenance and construction on site and during the summer months FKP is in full construction mode. It was not possible to schedule an interview though we had several informal conversations at Sette Cortili. The other employee is the graphic designer for FKP who had suffered a work accident the week I arrived and was in bed rest during my summer, making it impossible to conduct interviews.

The interviews with members from NICODEMO were arranged after I met some of the members at their summer film series. I could interview only two members as the organization's summer event scheduling did not permit other interviews

All interviewees were asked what exactly the organization did, how they started their organizations or working with the organization and why they chose to be a part of it. My intention was to discover their reasons for staying in Favara and motivation for creating social initiatives. I tailored open-ended questions.

Finally, during my residency I appointed myself keeper of the FKP garden at Sette Cortili and created a watering routine as a means to visit the site on a scheduled basis. My objective in watering plants at Sette Cortili was to slowly integrate among the residents there. I anticipated that a scheduled simple task could help me meet and talk to the local residents. This strategy proved to be successful and I even had helpers at the garden after a few weeks there.

\section{[3.2] PHASE II: URBAN ANALYSIS}

In order to understand the composition of the city's social spaces, public spaces and movement, the following maps were generated. The method and intent for each of these are described separately in the following section. 


\section{[3.2.1] Urban Frontage [Levels of Lingering- Urban Map]}

Favara's storefront shops and businesses were mapped in order to localize where social lingering occurs. In this research, lingering is defined as how long people stay in the shops and possibly carry conversations. This classification relies on my knowledge of residing in Favara and observing where people linger in the city. This also influenced my decision to not map smaller roadways since I knew them to be predominately residential.

The city of Favara is circumscribed by two major roads ways: SP80 to the east [the road's name changes from North to South as Viale Pierto Nanni, Via Vittorio Emanuele, Francesco Crispi and Bersaglieri Giuseppe Urso] and SS122 [Corso Vittorio Veneto] to the west. The historical city grows out from the intersection of Via Vittorio Emanuele and Via Umberto. Businesses with street front access were mapped using "Google Street view" dated 2008/2010. Some sites were adjusted and verified based on my residency and during a site visit to Favara in November 2012 since Google images were outdated in some areas. These were located on an AutoCAD plan for Favara (which was provided by Sicily Foundation) and colour coded to differentiate different store types.

Businesses were coded based on a 'Level of Lingering', which means the length of time spent in a specific shop and/or if any conversation takes place. The locations with the highest Level of Lingering are: restaurants, caffes, gelaterias and tabaccherie. A tabaccheria is a cigarette shop and convenience store. They are socializing hubs for men; the tabaccheria on Via Roma, just steps from Piazza Cavour, is a meeting place where men sit, lean and linger by the doorway any time of day. The locations with a middle level of lingering include small grocers, butcher shops, hardware stores and clothing stores. These places have a potential for conversation but are not busy social spaces as the highest level of lingering. The lowest level of lingering is for large grocery stores, pharmacies and banks, where there is less potential for social interaction and people only run errands

The purpose of this exercise was to highlight how social interaction in shops varies based on the type of store. In addition, this exercise exposed that the lack of businesses and services in the historical centre compared to SP80 and SS122 is an area less travelled and less potential for lingering. 


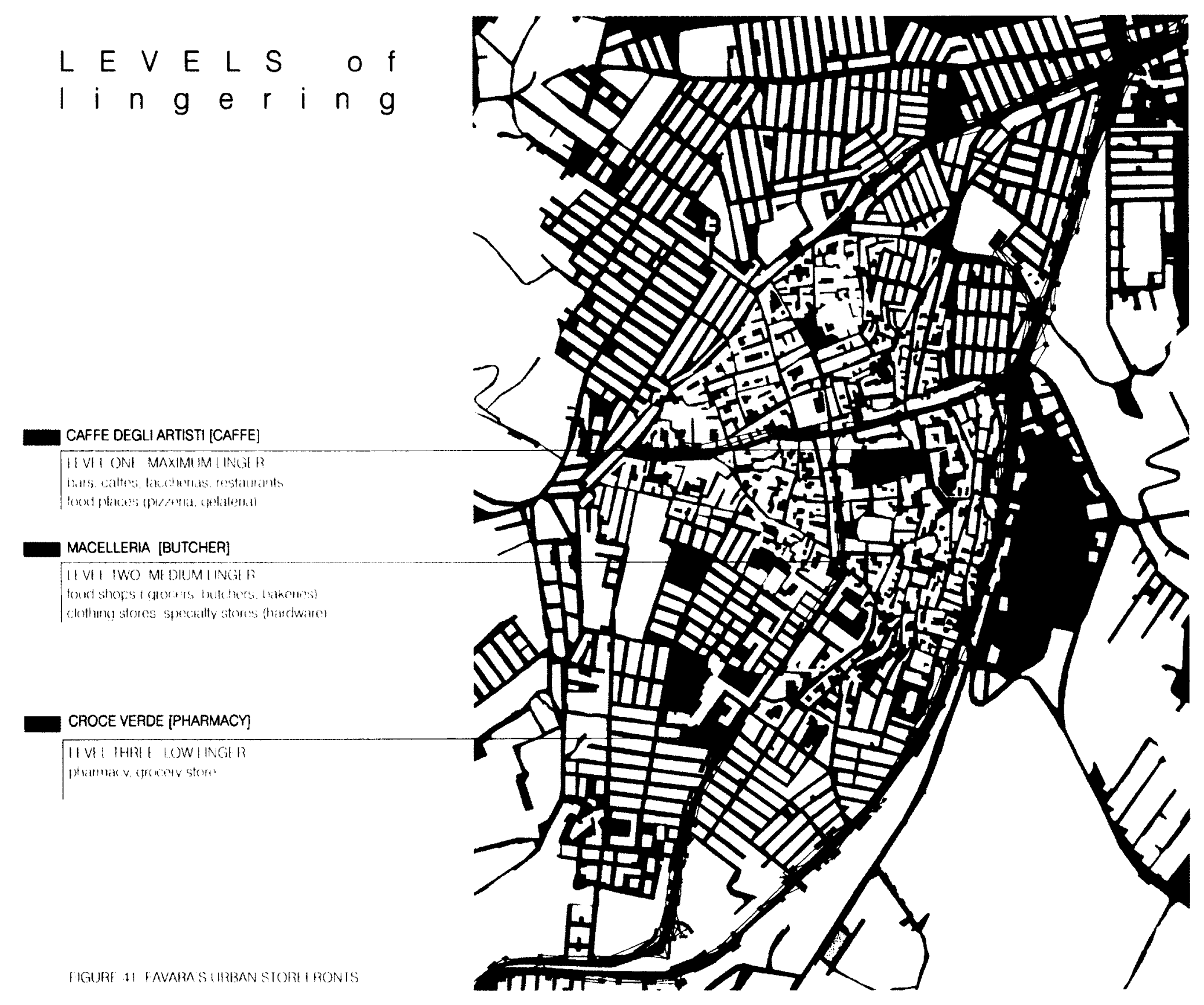




\subsubsection{Social Spaces [Degrees of Publicness -Urban Map]}

Favara's open public spaces were mapped and classified based on their degree of 'publicness' in order to locate where these existing areas are in the city. Based on the knowledge of the city of Favara, I was aware of a hierarchy among open spaces. I came to learn that a cortile is a form of public space. Cortili (plural for cortile) are the resultant space derived from the facades that contain it and they are typically oddly shaped. A cortile is shared by the residents whose houses open on to it, similar to a courtyard. It is uncommon for non- residents to linger in these areas even though they are public spaces. The FKP residence was inside of the Cortile San Vito and I came to understand this behaviour within a cortile.

The map was created based on knowledge of the city. I was aware of a few private abandoned courtyards since I had the opportunity to visit them with the property owners; these are the courtyard behind the public library, behind Palazzo Calfisi (next to the library) and behind sette cortile where the old cinema used to operate. The other courtyards were located via aerial Google maps and verified during the November site visit. The cortili were mapped in a similar fashion and I used aerial Google maps to cross reference locations. These were also verified in the November site visit since in plan-view they can appear as courtyards. All areas were located onto an AutoCAD plan of Favara and colour coded to differentiate types.

The classification of public spaces begins with the most open public spaces, the piazzas, followed by the cortile and the private courtyards, which typically hide behind the facades of the historical palazzi. The intention of the map was to highlight the existing open areas in order to suggest where local residents maybe gathering. Furthermore, my intention in mapping the private courtyards within this hierarchy was to expose the number of large green areas in Favara, many of which belong to old historic and abandoned palazzi and go used.. 


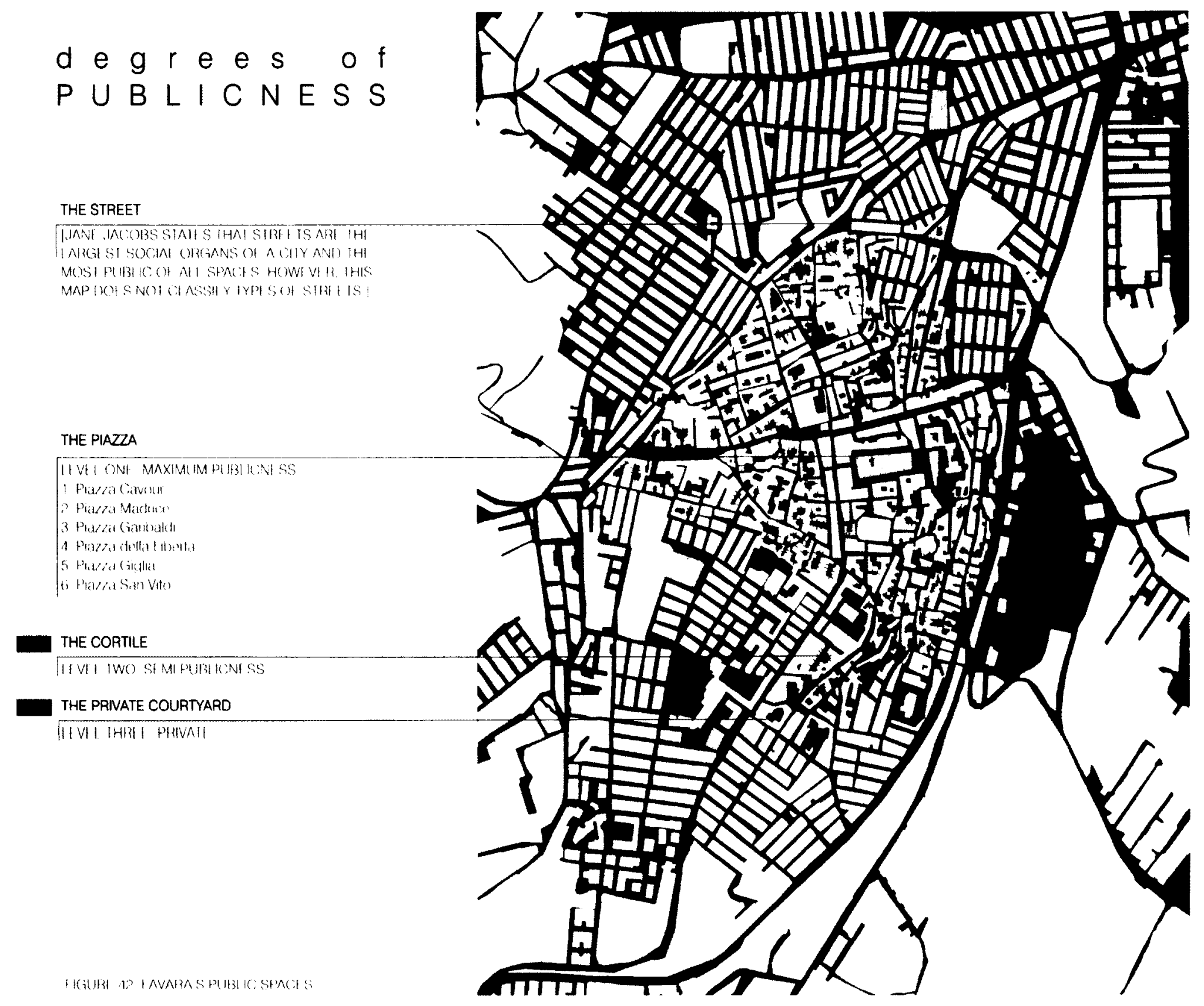




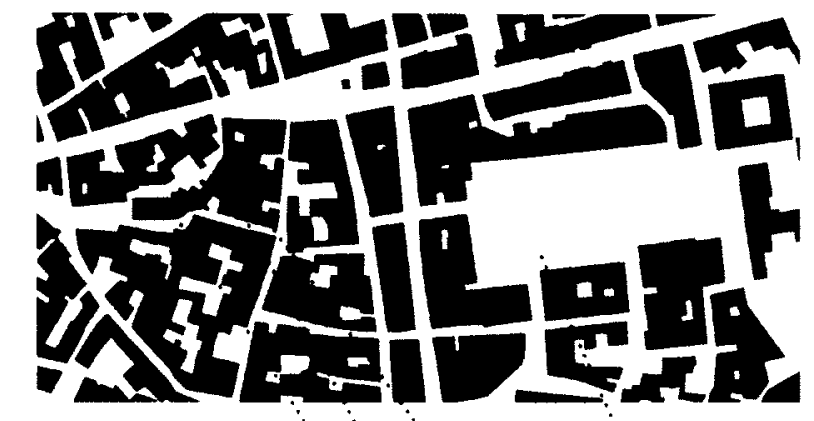

SANVHU)(HIIBSH ....... (GIIHII SAN VIIO

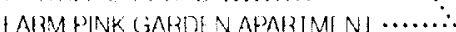
PIALLA CAVOUJPA
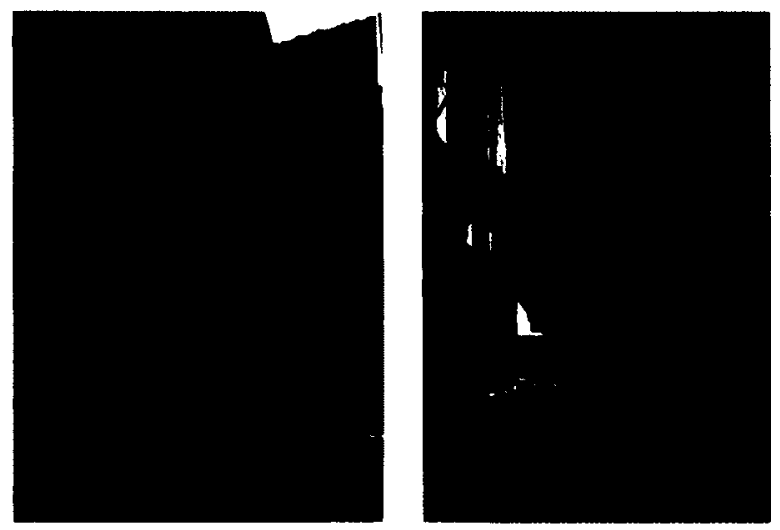

IGUAR A3 CORzIII E SAN VHIO

MAPO CORIIII SAN VITO CONIANS F KP OWNID

RI SIDI NCI IARM PINK GARIDIN APARIMINI BUILDINGIOISARE MAKRF D $1 O$ SHOW NIJMBBER OF BI SIIU NISIN IHI CORIII

IOP IMAC IF S INIRANCI IXIS IN ANOO OUI OF CORTHI

RIICHI HAND MAGS

I NRM PINK GARROT N APARIMI NI

\subsubsection{The Cortile [Urban Map]}

Based on the previous mapping study of public open spaces, this study extracts only the cortili in order to study their locations, average dimensions, areas and average distances to major roadways. The selection for this map, as with the previous ones, is based on the experience and knowledge of Favara's cortili. The map was made using the previously mentioned AutoCAD file of Favara which provided me with building outlines, as well as lot divisions. Using the previous map, I located only the cortili and drew lines from each cortile lot to the nearest major road. On another layer, I drew lines from each cortile lot to the nearest cortile. I recorded the longest and shortest of these lines in order to learn the farthest and shortest distance that local residents travel this area, which is typically by foot as some cortili are too narrow for cars.

This mapping study was designed to extract existing dimensions and proportions of the cortili with the purpose of using such dimensions within the design proposal. The cortile was chosen because of its role as a semi- public space. It is unique to the city and is engrained in its history. Cortili are microcosms of social activity, referred to as a 'shared living room.' They are common to the western region of Sicily and derive from Arab influences. Historically the cortile was the most important social unit, after the parish. In this area women would sew, children would play, animals were kept, and it was often used to cook with other neighbours. According to Gabaccia, the interactions among residents built social structures of kinship, trust and friendship (Gabaccia 1982, 55).

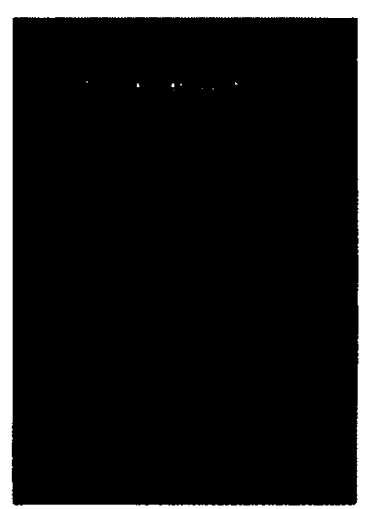

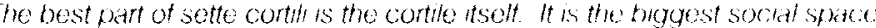
It has always been the public space. where people mix. It is the most hallurt space, there are no constraints or contusion regatding what is public and provete space Sure, the actual structure of the contlo ards in the ractivity. them ane no exits, only one entrance this gives an imner contite a senser of privacy thew sid sense of chosue. only one way to get in and out like a muscum. You enten athe exit from the same place and it gives the place a sense of securty. There sis com trol over who enters and exits. this is ombedded m the steucture of the spates. its ts own security" Vicenzo castell. tavara local 


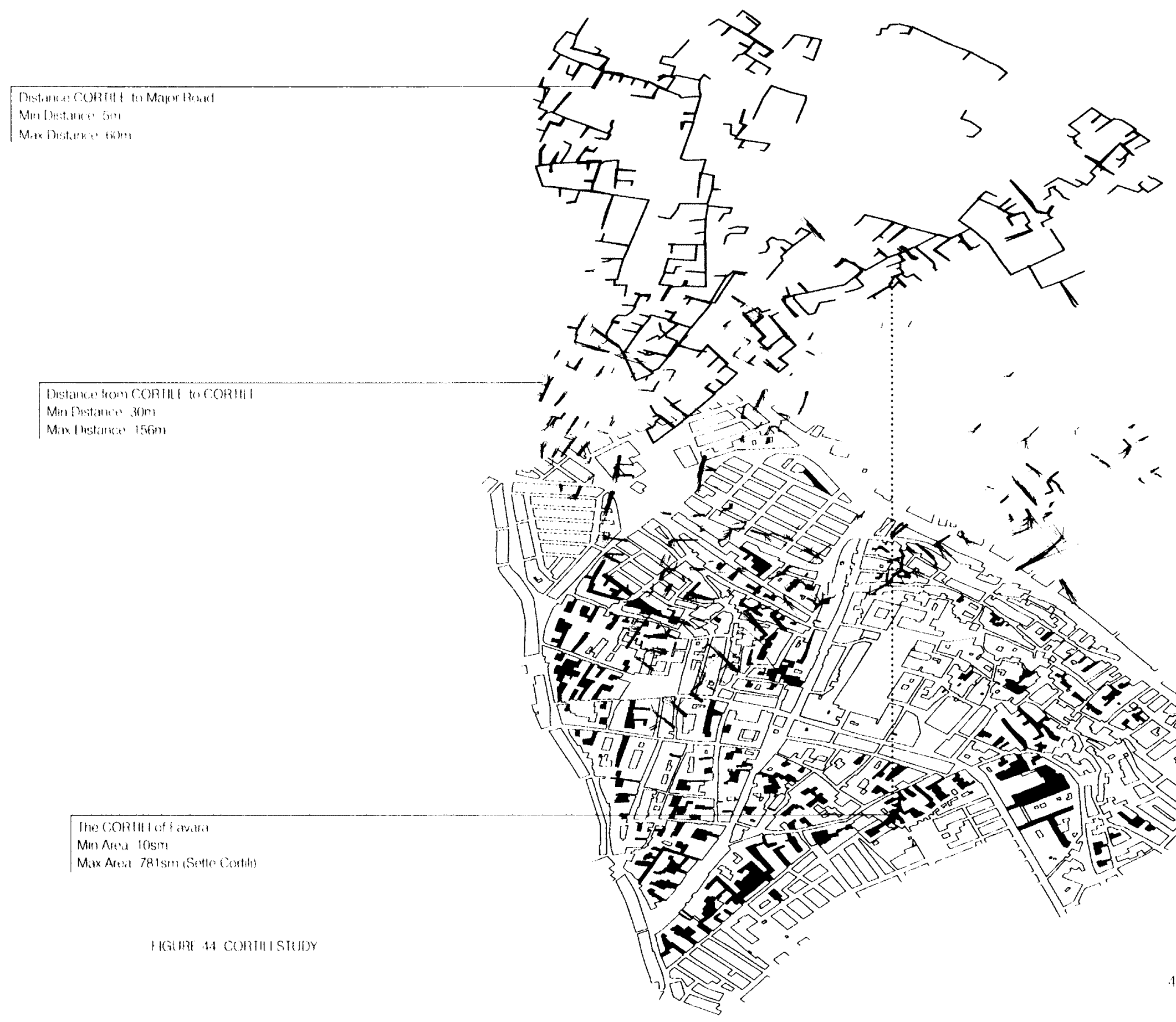




\section{[3.3] PHASE III: SITE VISIT}

In keeping to the nature of the research design which had already relied heavily on the voice of the locals, I found an opportunity to return to Favara. This site visit was in November 2012 and targeted Piazza Cavour. The intention of the visit was to source local opinions, thoughts and desires for what this space could be. Although it was a brief visit, I explored the possibility of collecting this information in an interactive way through an installation [see notebox project]. However, given time restraints and following the advice of FKP, who had the experience of staging projects in the piazza and seeing few results, the notebox was not constructed. Instead, I directed my questions to the Favaresi on a regional radio station, radioIN AGRIGENTO. Through a contact of FKP, I was allowed the opportunity to co-host on a radio program for an hour for one week. On the program, we talked about the Piazza Cavour, specifically what it has to offer and how it could be improved. On the air, I asked the Favaresi:

What would you like to see at Piazza Cavour? If you were mayor, what would you change?

In addition to this, my previous connection with FKP and NICODEMO assisted me with my fieldwork. I posted on their Facebook pages a digitally manipulated image of Piazza Cavour that I had constructed. This generated more responses online. RadioIN AGRIGENTO also posted the image of Piazza Cavour on their webpage after the first day on the radio program. Lastly, I questioned shop owners at Café Cavour, Café Umberto and Caffe degli Artisti and the owner of Hotel Belmont. While I was at these locations I also randomly interviewed customers at these cafés and posed the following questions;

\section{(1) Do you go to Piazza Cavour? Why? What do you do when you go there?}

(2) Is Piazza Cavour a space that belongs to you? Do you identify with the space?

(3) Do you think Piazza Cavour could be different? If you were the mayor what would you do to it? What would you like to see in the piazza? 


\section{r a d i o I N A G R I GENTO}

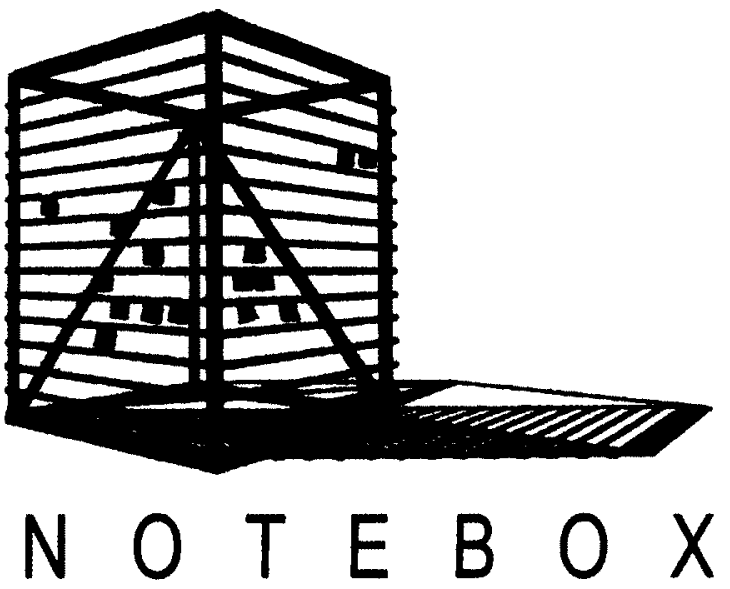

A DESIGN PAOPOSAL FOR A SIMPLE WOOD FRAME BOX THAT COULD BE PLACED IN THE PIAZZA, ALONG WITH PAPER AND PEN. AN ANONYMOUS CONFESSIONAL FOR THE PIAZZA WHERE RESIDENTS COULD WAITE THERE THOUGHTS, WISHES AND OUTRAGE. THE DATA WOULD BE USEFUL FOR DESIGNERS IN THIS CITY, BUT MOST IMPORTANTLY IT WOULD IGNITE CONVERSATION AMONG RESIDENTS. FOR SOME, THE BOX MAY ASK A QUESTION THAT SOME RESIDENTS HAVE NEVER BEEN POSED. THE POTENTIAL FOR THIS IS POSSIBLE MORE EXCITING THAN THE INFORMATION THAT MAY BE GATHER. IT STARTS THERE; ONCE A RESIDENT CONNECTS TO THE PLACE IN WHICH THEY LINE.

FIGURE 45: FAVARA SITE VISIT

1 - THE NOTEBOX, DESIGN INSTALLATION PROPOSAL 2. - RADIOINAGRIGENTO, NOV2012

3 - PIAZZA CAVOUR, FAVARA REIMAGINED

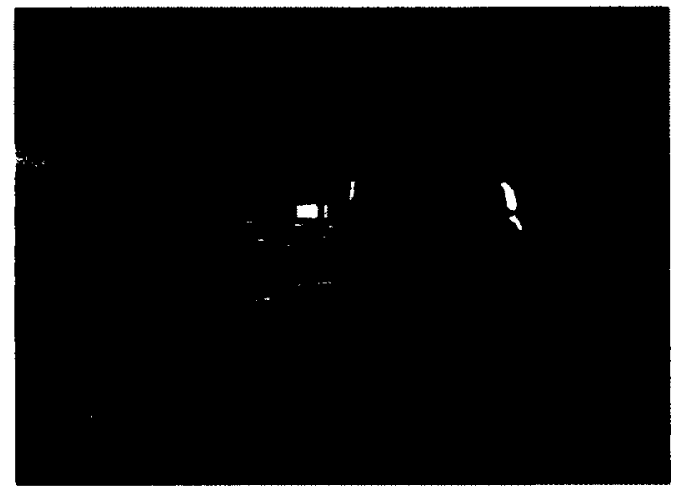

WHAT WOULD YOULIKE TO SEE HERE?

This historical image of Piaza Cavour was modified to provide a loud and catching unseen perspective of the pi azza in pink so as to initial conversation It was presented to participants as they shared their wishes for its revival. The image was used online via the facebook pages of FKP. NicoDemo. and radiolN Agrigento.

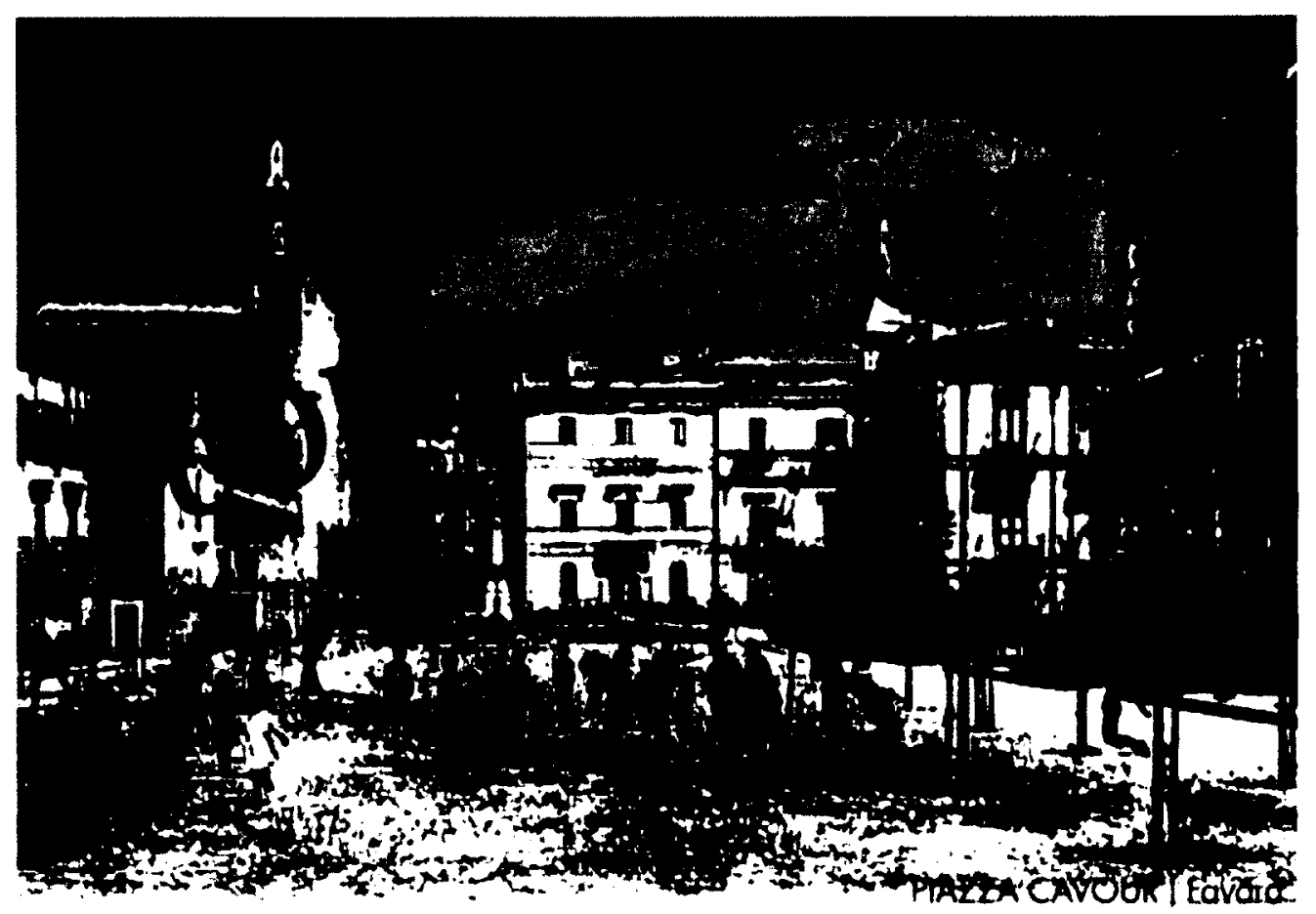


ENDNOTES

1. Daniele pario perra was a lecturer with the DSA Bologna program for Carleton University in January 2012. As a student of the DSA program, I was present at Perra's lectures in which he highlighted Favara and FARM Cultural Park. Perra is a designer based in Bologna and Calania whose work bridges between art, archilecfure, sociology, anthropology and design. He has taught within the faculty of Architecture at the University of Sapienza (Rome). Delft School of Technology (Rotterdam), Politecnico di Milano (Milan) and University of Denver (Colorado, USA). In 2010 and 2011 he published Low Cost Design and Low Cost Design II, respectively.
I recognize that customers who frequented these cafes had fairly positive opinions towards the piazza since they were already there. Other respondents were customers randomly chosen while they were at Café Itria and Café Montreal, both along SS122 [Corso Vittorio Veneto]. I chose these locations because they are places with high level of lingering and I anticipated to find people there I could talk to.

The purpose of asking the locals their opinion of Piazza Cavour was twofold. First, the responses could inform the design project and therefore propose a strategy that would reflect a local sentiment. Secondly, in asking these questions I expected it would generate conversation regarding the historical centre. Most respondents shared memories of the piazza and revealed a strong sense of nostalgia for what they recalled it to be and/ or wished it could be.

In sum, using an anthropological approach in phases 1 and 3 , it was possible to obtain direct information from the locals which could not have been obtained otherwise. The value in doing this is to respond to the specific local spirit of Favara and propose an appropriate design proposal. The key findings that are considered in the design phase are summarized and discussed in the following section. 


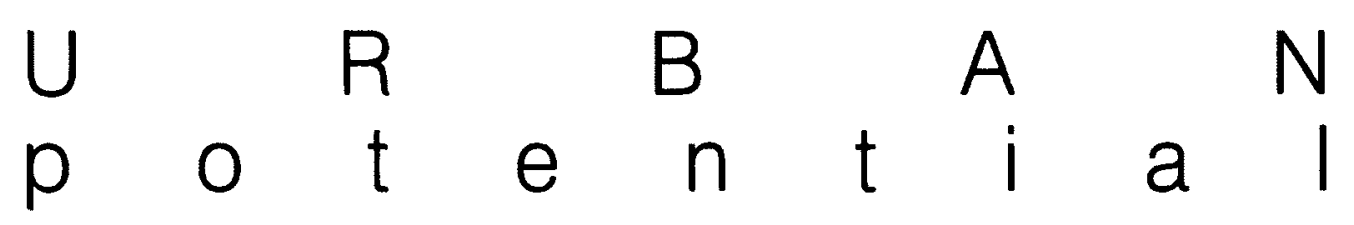

The mixed-methods qualitative research approach provided this study with direct information from the local residents which could not have been obtained otherwise. Each phase builds on the previous one and layers the social, urban and historical information regarding Favara's historic centre and Piazza Cavour. Having established that the genius locus of Favara is embodied in the local residents, it is necessary that the design proposal for Piazza Cavour reflect their sentiments. This chapter reviews key findings to be addressed in the design proposal and finally presents a newly designed Piazza Cavour.

\section{[4.1] RESULTS: 4.1.1 Phase 1: Residency \& Interviews}

The project relied on this phase because as a resident in Favara, the social and urban issues were observed first-hand. My residency revealed Piazza Cavour as a desolate place, frequented only by retired men. It prompted me to question why people had stopped going to the piazza and if they were not there, where were the social spaces of Favara? Living within the historical centre also exposed a reality of a city I could not have anticipated. Areas of the historical city were truly abandoned, streets were littered, there was no regular garbage pickup and there were periodical water shortages. Above all, l observed a social isolation since many houses were empty. Yet, this was contrasted by the social phenomenon that occurs within the cortile. As previously mentioned, this is a culture in which only cortile residents take part in. Living in Cortile San Vito at the FARM Pink Garden Apartment provided me with the opportunity to be an observant and participant of the life in a cortile. Finally, living in a city in which there are no major social spaces tailored to young people, no cinema, or public library it was difficult to understand why people would stay in the city of Favara.

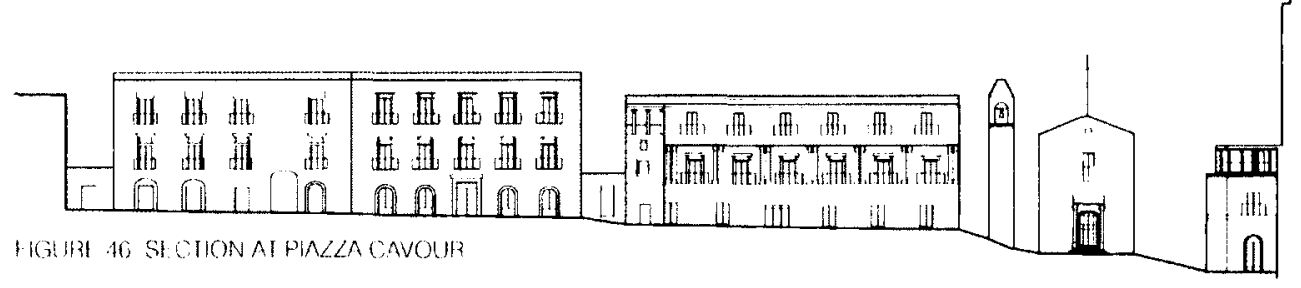


I came to answer this question as I met more socially active local residents, specifically those from FKP, SF and NICODEMO. In my interviews with them I came to source the root of their motivation and attitude towards Favara. That being, their sense of social rootedness became the catalyst for the thesis. Lastly, this phase established a network for me in Favara that facilitated my site visit in November of that year and which helped me throughout the research of this thesis in obtaining images and information.

\subsubsection{PHASE II: URBAN ANALYSIS}

Dissecting the city to locate a hierarchy of social hot spots for lingering in Favara exposed a lack of these social hot spots in the historical centre. Although there are currently three cafés at Piazza Cavour, two of which opened only in 2010 and 2012, there is no network that connects them to the city. They are isolated from the busy street life that occurs along SS122 [Corso Vittorio Veneto].

In addition, the study of open public spaces revealed a series of piazzas, an abundance of cortili and private courtyards, all of which are fairly disconnected from each other. However, from this study micro social culture of the cortile was exposed. The cortile was historically a social hub of residential life. Today, the inhabited cortili of Favara continue to be used as social spaces, such as Sette Cortili where the ladies bring their dining room chairs outside in the evenings to talk and children ride their bikes. Inside Cortile San Vito, a much smaller cortile, the same scene unfolded while I lived there. This is significant since it proves that the locals living inside the historical centre still use the cortile as a social space. The cortile study exposes critical dimensions and reveals a local urban condition rooted in centuries of building history that continues to dictate inner city travel and dimensions for what is considered a comfortable public social space. 


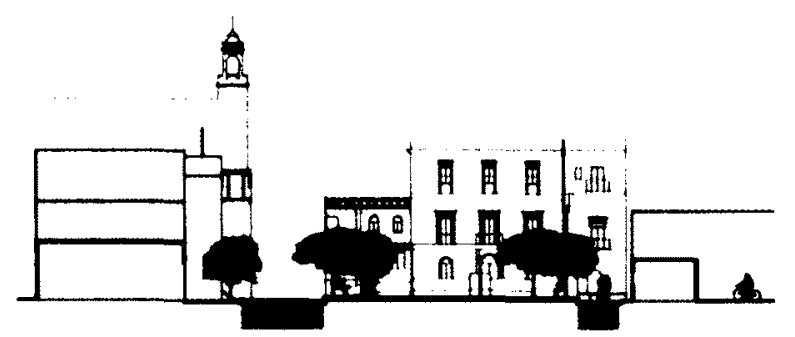

PH DE SIIIAN ZONI

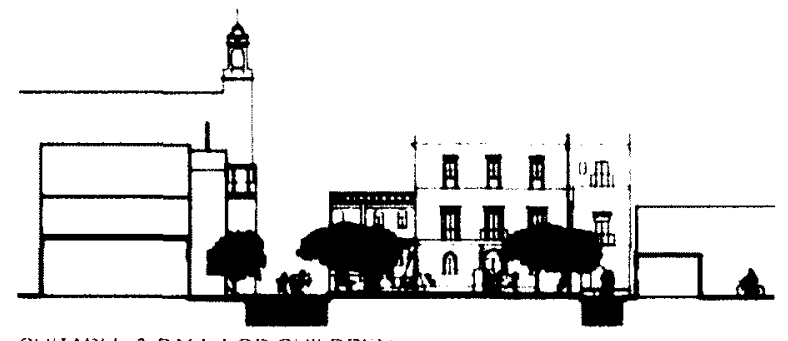

SUIIABIL \& SAI H ORCHILDFIN

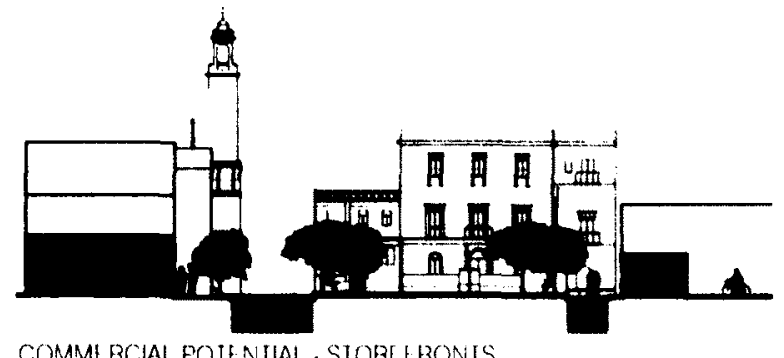

COMME RCIAL POIL NIIAL - STORT H RONIS

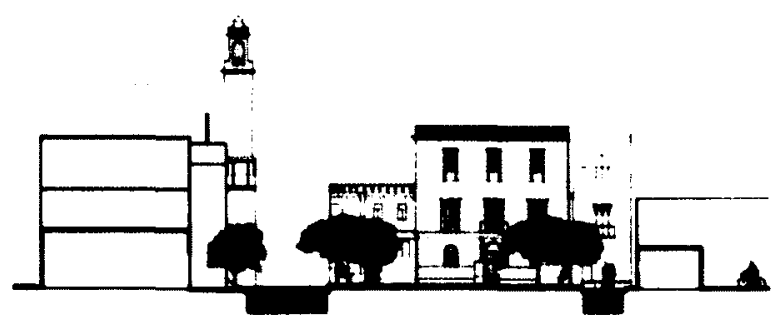

RE-TVAIUATION AND USE OF KEY HISTORIC PROPERIIIS

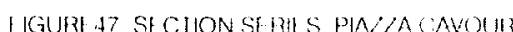
BASF DON HII DWORK HP SIIIS

\subsubsection{Phase II: Fieldwork Question Results}

The site visit provided the opportunity for interviewing the local residents about Piazza Cavour and what they wished to change. Responses were obtained via a one hour radio session on radioINAGRIGENTO and they were asked:

What would you like to see at Piazza Cavour? If you were mayor, what would you change?

This question was also posted online via the Facebook pages of FKP, NICODEMO and radioINAGRIGENTO. Participants interviewed in person were asked the questions below.

(1) Do you go to Piazza Cavour? Why? What do you do there?

(2) Is Piazza Cavour a space that belongs to you? Do you identify with the space?

(3) Do you think Piazza Cavour could be different? If you were the mayor what would you do to it? What would you like to see in the piazza?

The following results are a synthesis of both groups; note that the radio participants and online responses contribute only to question (3)

[1] Not all of the participants go to Piazza Cavour. In fact, approximately half' of the respondents said they do not go because (i) there is nothing to do and (ii) there are only elderly men. The others who do frequent the piazza go to (i) have a coffee and/or aperitivo at a café, (ii) to use the post office (iii) have matters to resolve at the municipal offices and (iv) for religious events.

[2]Those who went to Piazza Cavour said they do identify with the space and feel they belong there, which was also why they continue going, even if for a coffee. One respondent said she sometimes brings her lunch and meets her friends there, "because that's what you do in a piazza, you eat in public."

[3] The top responses expressed by respondents were the following: (i) a piazza without cars (ii) a space that children and adults alike could enjoy (iii) a revival and appropriate cultural use of the historical castle (which currently has irregular hours, no defined program and, hence, is not frequented) and the public library (iv) a flexible yet permanent space for events, such as musical performances and outdoor films and (v) a water feature that recalls the fountain of Piazza Cavour as it was in the 1960s. 
Other common comments were (i) more shops, specifically bookshops, eateries and evening venues, (ii) public bathrooms that are respectful of the piazza and well designed (currently there is a small house in front of the public library with a door that does not fully close and has made the public restroom of the surrounding area) (iii) improved safety and security through lighting and clear views in and out of the piazza.

The responses were what I had anticipated. I knew the piazza was poorly frequented, although it was still surprising to learn that so few people go. I was also surprised by a number of participants that advocated for a city library and did not know there is one at Piazza Cavour, which is currently closed. This exposed how little some locals know this area of the city. Moreover, the greatest surprise was the fountain that once stood in Piazza Cavour. This was information I did not have before questioning the locals. While there on my site visit, I was able to acquire an old photograph. However, there was no information available at the municipality regarding the life and death of the fountain at Piazza Cavour. Yet the most powerful evidence is in the number of participants that knew about the fountain and advocated for it, some of which would had not been born when

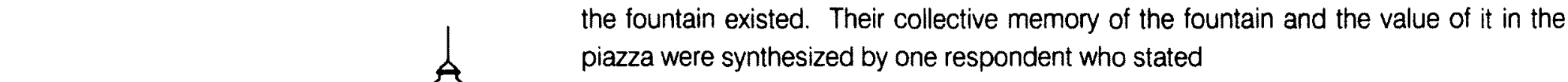

"What kind of piazza does not have a fountain anyway?"

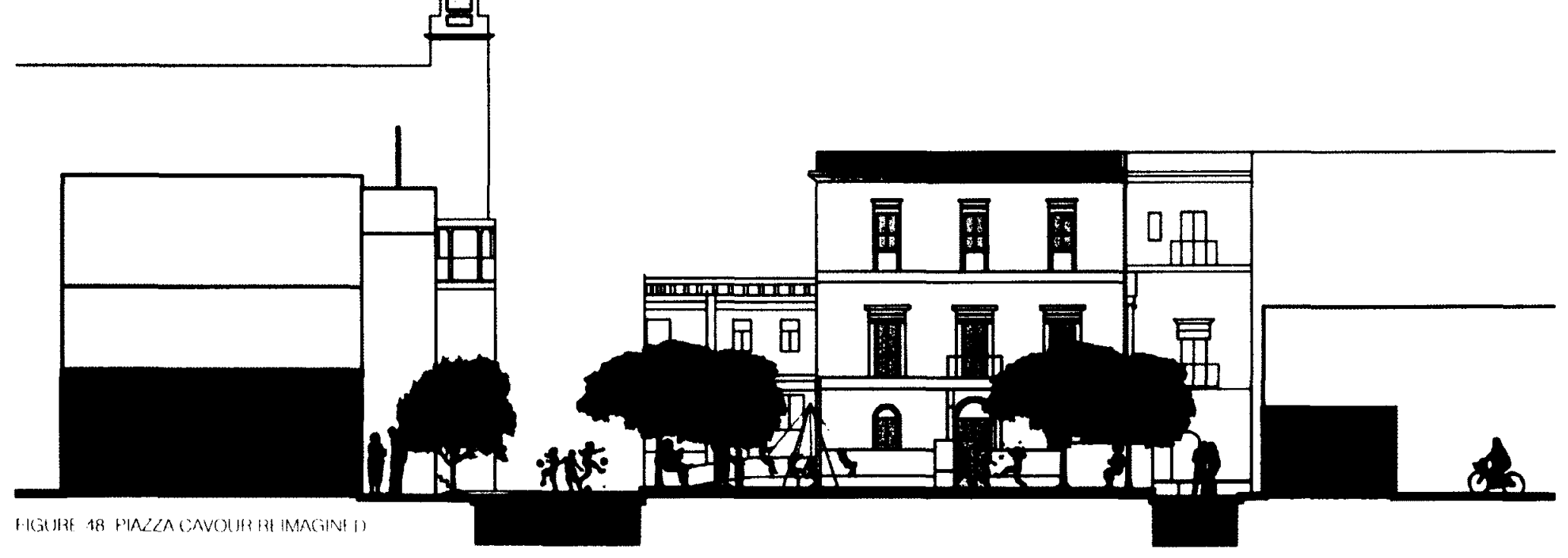




\section{[4.2] Piazza Cavour: EXISITING CONDITION}

Favara's Piazza Cavour dates back to the 13th century. By the late $15^{\text {th }}$ century it was known to be a vibrant city social space that served as a religious, cultural and commercial venue (Sciara 1997, 22). It is delineated by several historical landmarks including the 13th century Castello Chiaramonte, the Church of Santa Rosalia ( $17^{\text {th }}$ century), the Church of Santa Rosario (18 $18^{\text {th }}$ century) and nine noble houses, known as palazzi. The central palazzo, Palazzo Mendola ( $19^{\text {th }}$ century), houses the municipal offices. At the east end of the piazza is the public library, Biblioteca Mendola (early $20^{\text {th }}$ century). There are few socially active spaces in the piazza as several businesses began to close in the mid1980s and early 1990s. However, Caffe Cavour, a family business located at the west side of the piazza remained open, as well as two barbershops. Another active space in the piazza is the retired miners' union community centre in the south west corner. Unfortunately, with the few businesses that remained open and catered to only one demographic group, women, families and young people stopped going to Piazza Cavour and it became dominated by elderly men².

Beginning in the mid-2000s, Piazza Cavour entered a phase of revival. The mayor had the old municipal offices renovated and in 2006 city officials relocated back to the piazza. Hotel Belmont, the first hotel in Favara, opened in 2008 just south of the piazza and challenged the city to rezone the narrow street next to them as a pedestrian walkway. The following year Hotel Belmont opened a restaurant once the city had granted their zoning request. ${ }^{3}$ Today, this narrow lane of no more than $50 \mathrm{~m}$ is the only zoned pedestrian lane in the historical city. Early in 2010, Caffe Umberto opened at the east corner. Owned and operated by two local men in their late 30s, this was the first space that stayed open past 7 p.m. Offering a typical aperitivo, ${ }^{4}$ Café Umberto was the first venue tailored to young people in the piazza. A second café/bar opened in July 2012, Caffe degli Artisti, which is also owned by Favara local residents. It operates as an afternoon/evening venue and attracts more young people to the piazza. Lastly, Piazza Cavour saw a new addition in December 2012 when the old Caffe Italia reopened. Originally a family owned and operated café/bar; it closed its doors when none of the family members wished to continue the business. Two young men, one from Favara and the other from Agrigento, took over the space and opened a pizzeria maintaining the original name. ${ }^{5}$ 
$E \times|C T| N G$

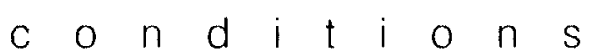

AREAS ACCESSIBLE TO PEDESTRIANS

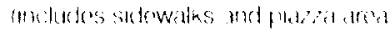

AREAS ACCESSIBLE TO VEHICLES

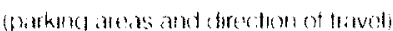

AREAS NOT ACCESSIBLE TO VEHICLES

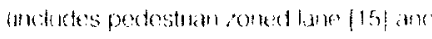

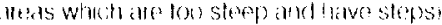
AREAS OF ABANDONED POTENTIAL

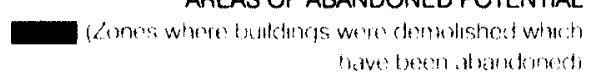

DESTINATIONS AT PIAZZA CAVOUR

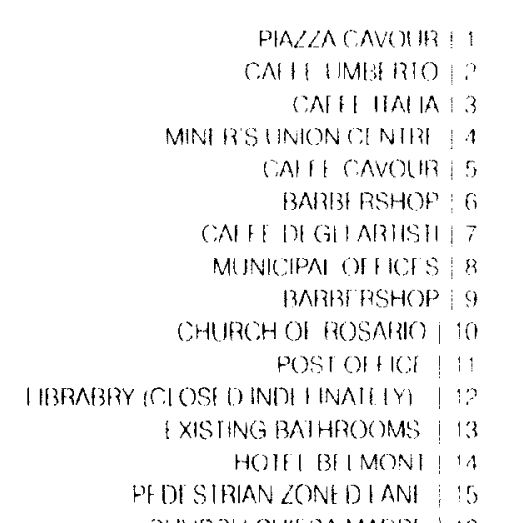

IIGURE . 19 I XISTINGCONDHIONSAI

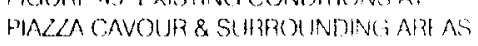

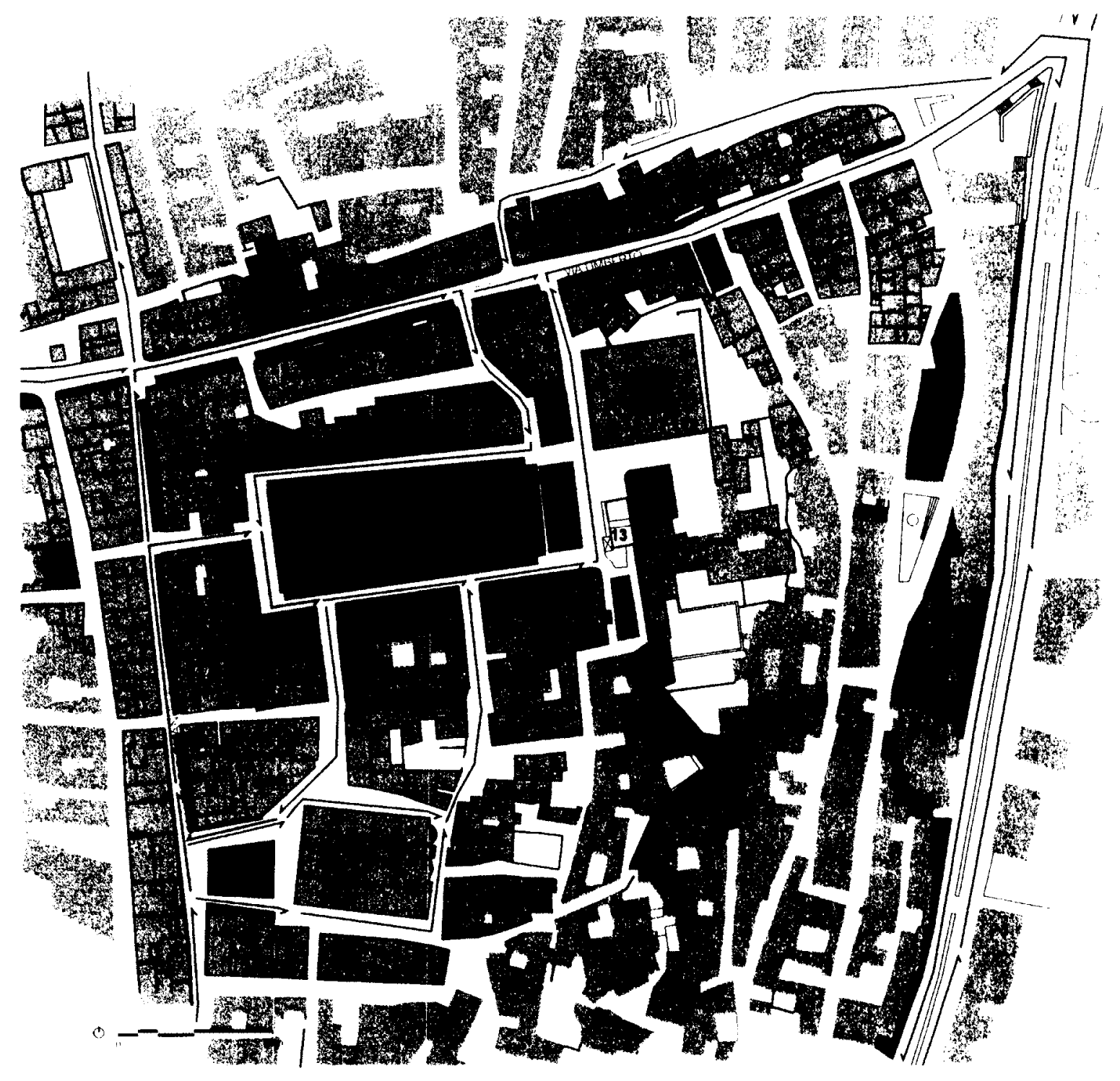




\section{VIA UMBERTO}

Distance. Vittorio Emanuele - Corso Veneto: $350 \mathrm{~m}$ Change in elevation: Vittorio Emanuele - Corso Veneto: $23 \mathrm{~m}$

Existing sidewalks widths: $0-1.1 \mathrm{~m}$ Average width: $0.8 \mathrm{~m}$
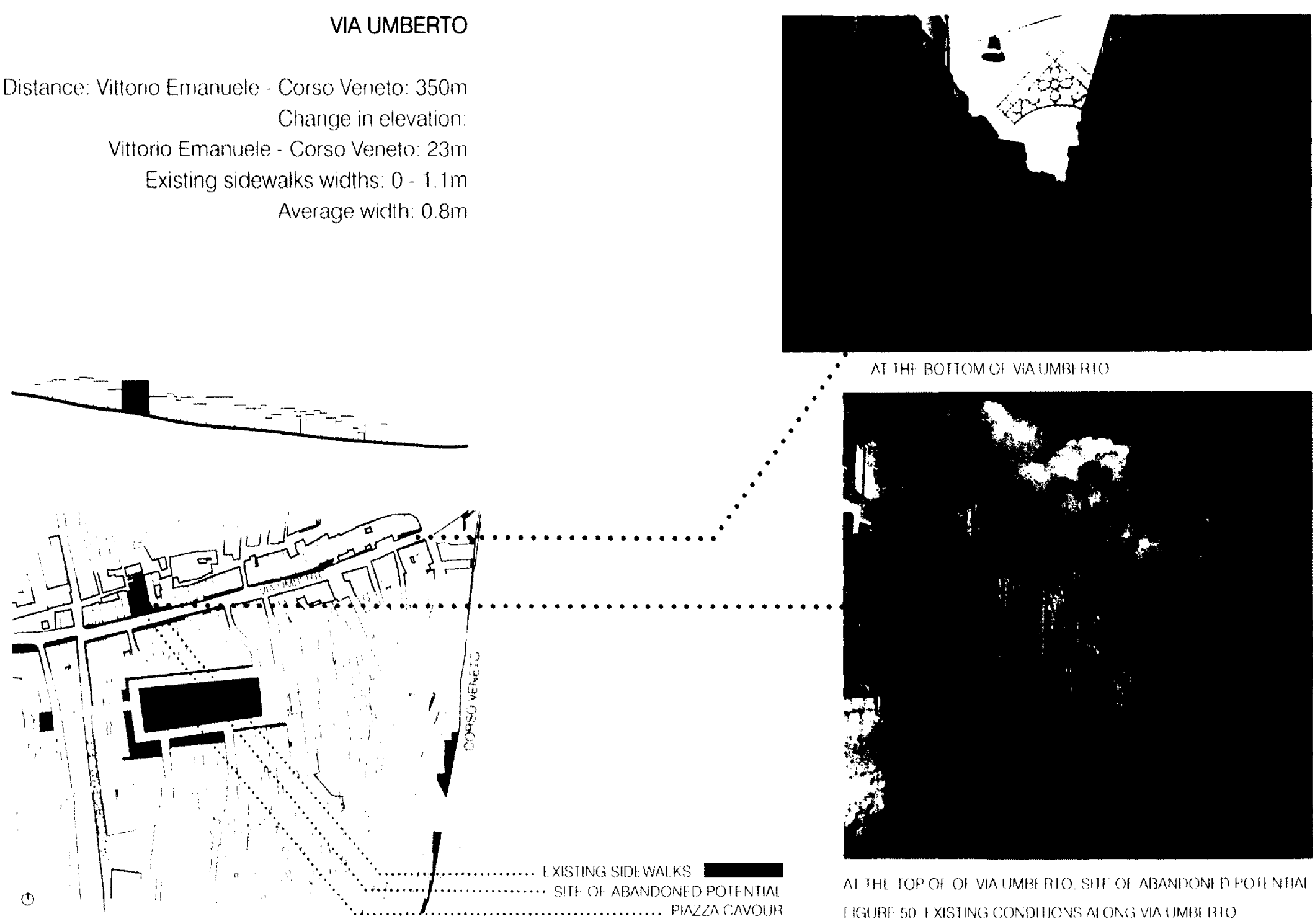

AI THL IOP OF OI VIA IIMBB RIO. SHI OI ABANIONI D POHI NIAI

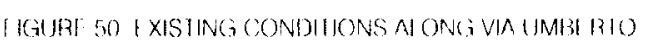




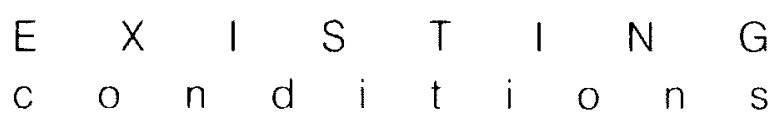

VIA VITTORIO EMANUELE

Distance

Via Umberto - Piazza Chiesa Madre: 170m

Change in elevation:

Via Umberto - Plazza Chiesa Madre: Om

Existing sidewalks widths: $0-0.8 \mathrm{~m}$.

Average width: $0.65 \mathrm{~m}$

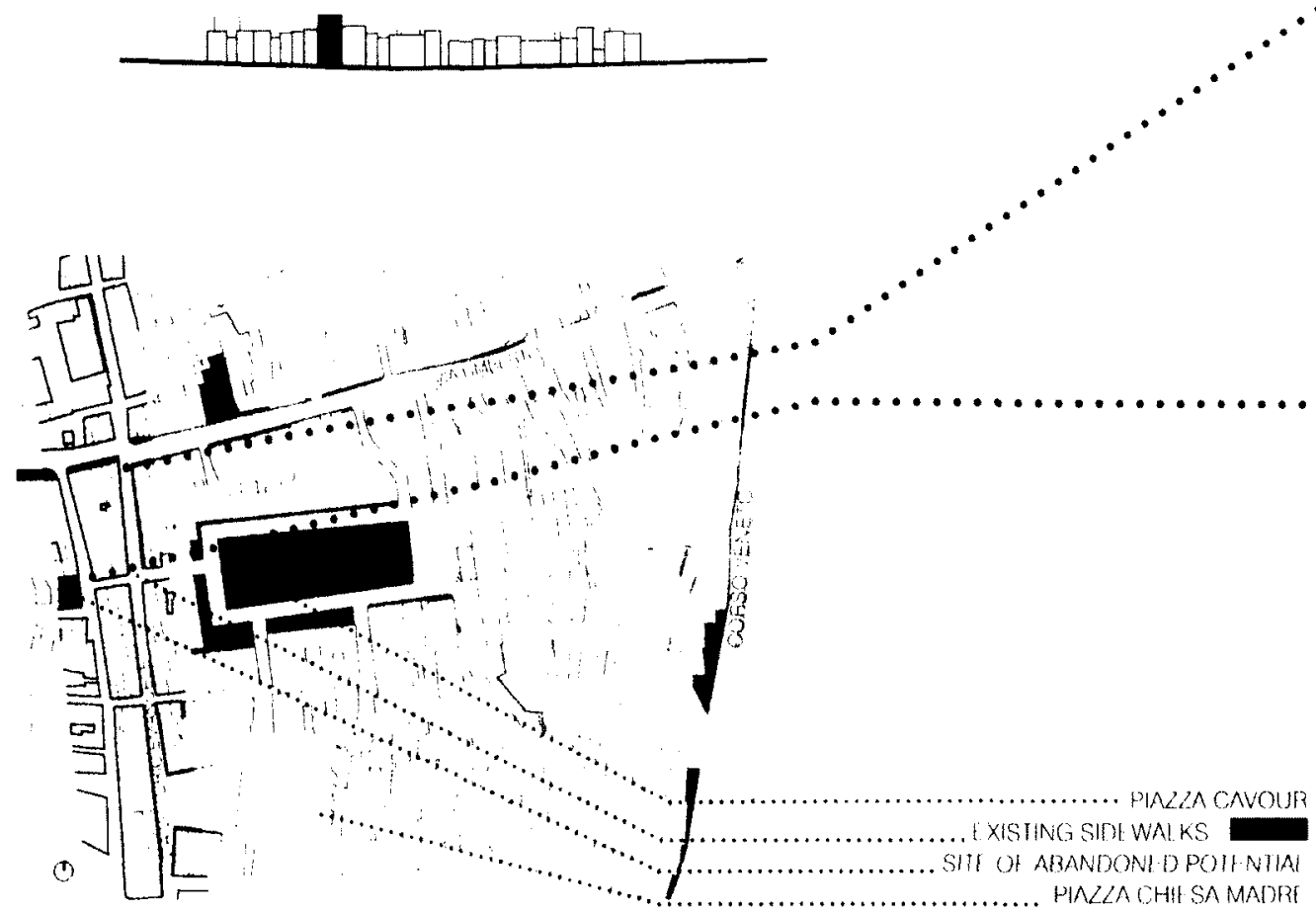

VIA VII IOHO E MANULHI

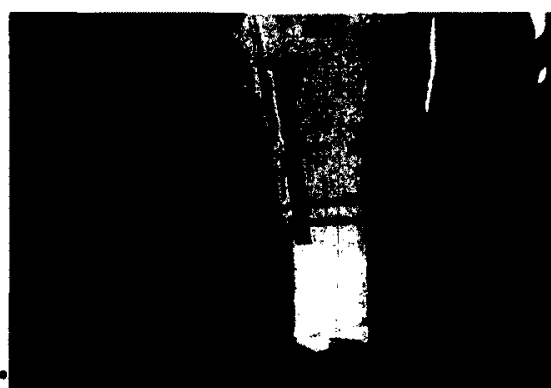

BF HIND VIA VITIORIOI MANUIII SIII OH ARANIUONI I) POII NIIAI HGIII? SI IXISHING CONDHIONS AI VIA V I MANHIII 


\subsection{Piazza Cavour: PROPOSAL}

The typical reaction to Piazza Cavour is "there is nothing there but old men." 6 In hearing from the local residents and witnessing who frequents the piazza, it appears that the Favaresi require more than a few cafés to attract them there. While the recent businesses have been successful, the design project it will not propose new stores or cafés. These rely on economic stability to remain open and assume all locals can afford to frequent them. The intent of the project is to reconnect the piazza beyond the historical centre. This will be achieved by designing existing social spaces in the historical centre; Piazza Cavour and the roads that connect it, in a manner that reflects the morphology and history of the city in order to offer a new social space in Favara.

The qualitative and quantitative interviews and mapping of the city respectively outlined three significant issues to be addressed in this design proposal. The first issue is the white zones (ruins) in the city where 'abandoned potential' lies for these to serve as social spaces rather than voids. Secondly, the issue of water proved to be deeply rooted in the city's history and carved into the locals as a social ill. Third, considering the social nature of the cortile, ingrained in Sicilian culture and built environment, the concept of this small intimate space is reflected in the newly designed piazza. Finally, the various parts of the project are connected along the major roadways of historical city; Via Umberto and Via Vittorio Emanuele. This will be achieved by phasing the design proposal.

[PHASE ] The intent of the first design phase is to redirect movement towards the historical centre and to Piazza Cavour. This involves a change in pedestrian and vehicular travel. Pedestrian travel is prioritized through the design of new sidewalks that are consistent and much wider than existing ones. There are several resting platforms along the way because of the steep incline along Via Umberto. These are treated as distinct spaces and offer shading and a place to sit as well as a tall curb wall in order to further separate pedestrian and vehicular travel. Sidewalks and rest stops are accommodated before car travel or parking zones in and around Piazza Cavour. As a result cars are rerouted and no longer enter the piazza. Existing parking areas along Via Vittorio Emanuele are relocated along the north side of Via Umberto which is much wider and can accommodate these.

Within this phase, two sites of abandoned potential close to Piazza Cavour are established. Each offers a basic programmatic function and is manifested in the design of a 


\section{ENDNOTES}

1. Total sample includes radio callers, conversations with plazza shop owners, young people approached in cales, various people encountered in Favara and Facebook respondents. The total sample tor question (1) is 35, tor question (2) is 35 and for question (3) are 58 . This difference in semple size arises because Facebook respondents were only asked question (3) in order to make commenting easier and encourage more people to participate.

2. Based on conversation with Catte Cavour owner.

3 Based on convereation with Hotel Belmont owner. He stated that desplte the pedestrian sign they still had scooters diting through the lane. They repaved the laneway, added lighting and placed patio tebles outside and boltards at sech end of the lane. These measures were finally enough to dlscourage scocters.

4 Many bars and ceste through ltaly and Sicily serve an apertivo; with the purchase of one drink, a small buffet of appetizers is available. This is often an inexpensive way to "eat out" for young folks.

5. Besed on conversation with Caffio thalia property owners.

6. Bused on conversations wth young folks (mid 20s-mid 30s) at Calfe Umberto. Also based on 3 separate conversations with 3 people between 25-30 who explained that having been raised outside the hietorical cty, they nover went as children. Growing up they leamed that only old men trequent the plazza. Of these 3, only one

has atarted stop at the plazza for coftee or an aperitivo. tower. The tower along Via Vittorio Emanule is located on a large lot and is designed to be a potential micro social space. It can serve as vestibule to the cortile system behind it which previously could not access Via Umberto from here. The tower on this lot aims gently touch down on the site without filling the lot or imposing on it. It is a place to meet that becomes a landmark along the street and in the city. It functions as the Lookout Tower, offering a few small viewing platforms along the climb to the top. At its full height, a person has a view of the Favara skyline and Piazza Cavour, which is not offered in any public space in the city. Finally, at the base of the tower are basic facilities, as the existing ones in front of the public library in Piazza Cavour are removed.

The second tower is located behind Via Vittorio Emanuele and has a direct visual connection to Piazza Cavour. This tower offers the experience of water; in sight and sound, signaling when there is water in the city as it taps into the local system. It has the potential to store rainwater which can be used when city resources run dry. Water is pumped up and out of the tower along it's west façade but is captured by an overhang roof which drains water back into the tower, thus continuously cycling the water. The water façade of the tower faces Piazza Cavour and Via Vittorio Emanuele and hovers above the street skyline, making it a visual marker in the historical city.

[PHASE II] The focus of this phase is the piazza. This begins by reconnecting it to Via Umberto and Via Vittorio Emanule along a few major walkways which are now free of vehicular traffic. Secondly, the piazza itself is redesigned and divided into major and minor spaces. These are inscribed through a change in materials and planting. The major spaces are open and free of obstructions in order to allow for various activities to unfold. The minor spaces, 'the cortile spaces', offer small intimate areas within the vast open space of the piazza. Lastly, the water is reintroduced into the piazza through a new fountain. Designed as a sculpture as well as a water fountain, it remains as a symbol in the piazza even when there is no water. The edges of the fountain follow the slope of the piazza, whereas the fountain area is dropped slightly, creating edges at various height for sitting and leaning. Accessed from all four sides, the fountain encourages people to enter within it and get wet 
[4.4] DESIGN PORTFOLIO 
$\begin{array}{lllllllllll}C & O & n & c & e & p & t & a & \text { I } \\ D & E & V & E & L & O & P & M & E & N & T\end{array}$

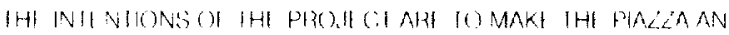

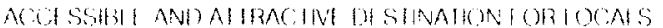

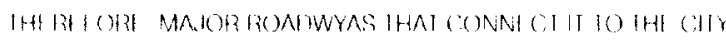

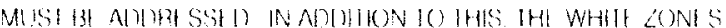

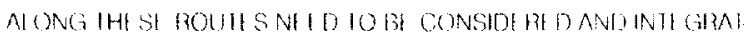

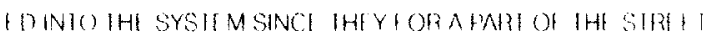

IHAT HI AOS IO IHHI PINZLAA

SI CONIIY MINOR CONNI CINE ROADSII-ADINGTQ IHI PIALLA

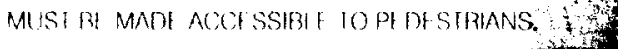

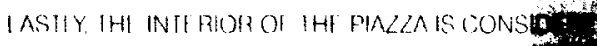

SITES OF

ABANDONED POTENTIAL

PAVILION DESIGN

ACCESS TO PIAZZA $\ldots . . . \ldots . .,:::$ :

CURATED STREETSCAPES

ACCESS TO PIAZZA $\ldots \ldots \ldots \ldots \ldots$.

PEDESTRIAN ROADS

PIAZZA INTERIOR

FOUNTAIN

................

IKAJRI S? CONCI PIUAI SK! ICH 


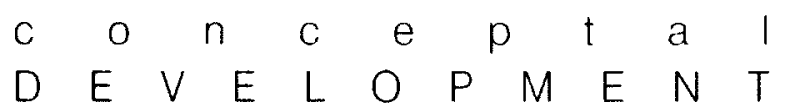

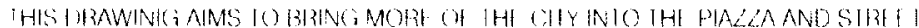

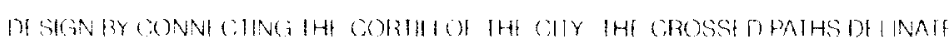

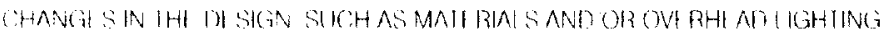

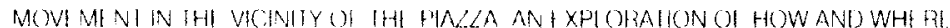

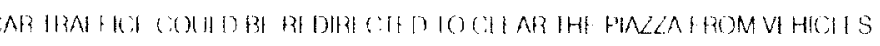

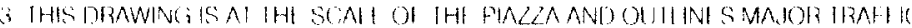
IIOWS HROM CONNN CIINGS SIRI IS IHI INIIRSI CIION OF IHESL PAIHWAYS CIRCOUMSCARIBS SIHA IOCNIION OH IHF FOUNIAIN
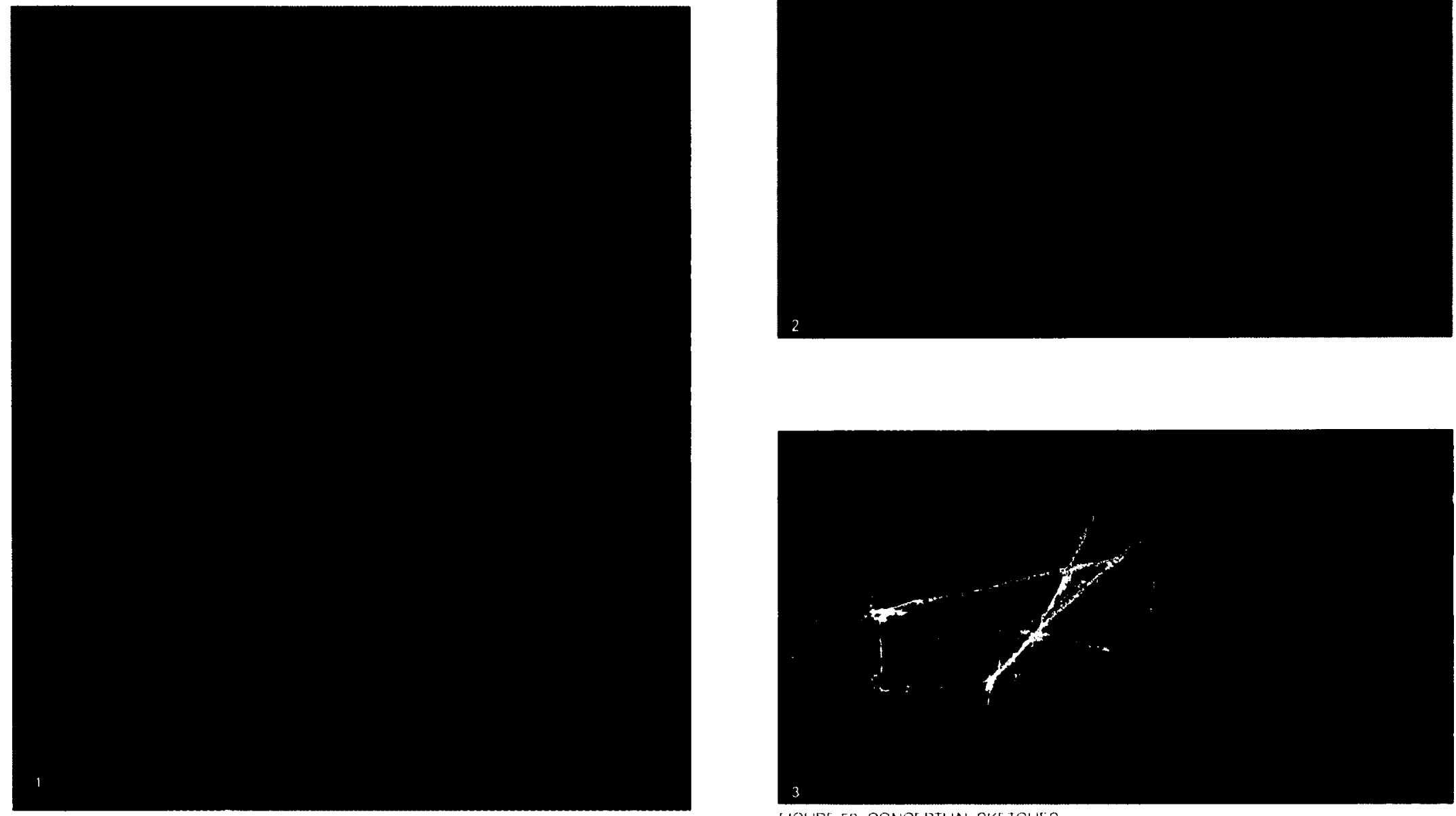


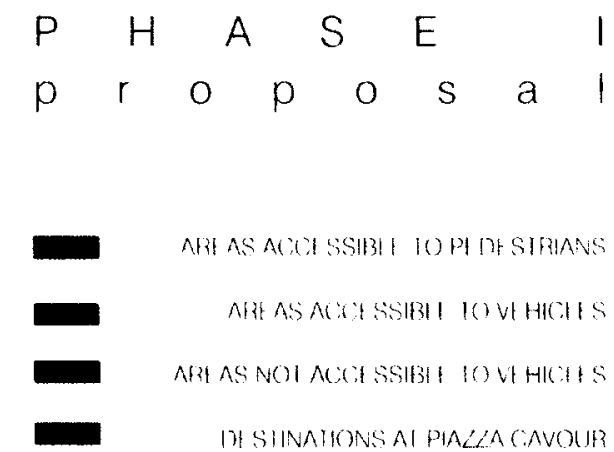

IPHASH 1. CONNE CINA ILSSII!

NI W WIOE R SODI WAI KS AIONL VVIA (IMBZIRIO)ANII) V I MANIUII AND) SF VIAI RESTING PLATFORMS AI VIA (UMPI IRIO

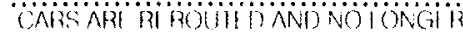

I NIIRTHE PINZA

IABANDONH OPOII NIIAI VIA IIMIBY RIO) THE LOOKOUT TOWER ... OHHRSAIIWSMAII VII WING PIAI. IOIMS ALONG IHI CLIMB IO IHE TOP AI IISALII HE KGHI A PIRSON HASA VII WOH IHI I AVARA SKYIINI AND PIALZA CANCHIR? Al THE BASS OI IHF IOWI RARI FASL IACHIIIS S I XISIING WC IN HBONI OH IHI

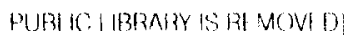

IVIA $\vee$ I MANI I I I WATER TOWER IOCAIS D BF HIND VIA VI MANU IF II AND HASA DIHA CI VISUAA CONNI CIION 10 PIALZACAVOUIR THIS IOWEROHHBS IHI EXPI RIE NCE (OH WAII R. IN SIGHAI AND SOUND SIGNAI ING WHIN IHERI IS WAIIR IN IHI CIIYASII IAES INTO IHI IOCAI SYSIIM II HASIHI POII NIIAI IO SIORI RAINWAIE R WHICHCAN BI IISH DWHEN CIYYAISOURCAS RIN ORY

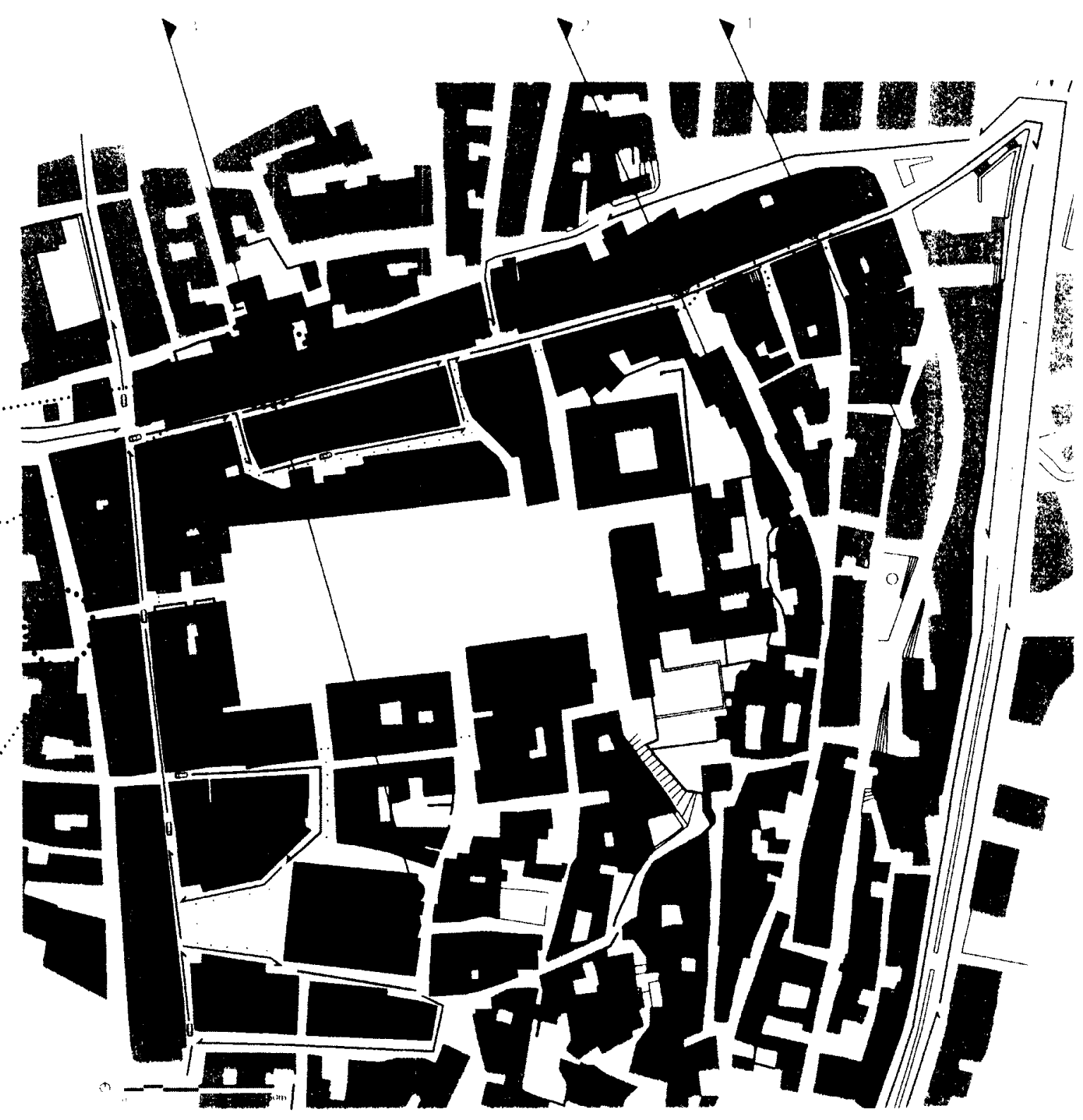


IYPICNA SHDI WAIK SA CIKON

WIDHHS VABY I BOM? IM-I IM

CONSEII NI ONBOHHSIOHSOF THE SIHFH

PINALINGOCCUISSONIY IN WIDI ARE AS

IHI SII DWA K MIIZCOS SPACH OR

COHIIIOOCOHAS IN AII W PIACIS WHI BH SPACI AIOWSIOH IHIM

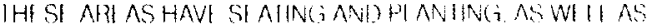
CRIB WAII ASA ST PARAIION GROM IRAN HIC:

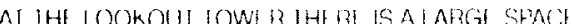

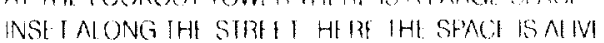
WIIH TREF SANT SI AIINSO

IHI IOWHRCANBB ACCISST D IO AIIANA VIE WSO

IHI CIIY

AIGBADI IHI BI AHI BAIHROOMI AOMIIIIS

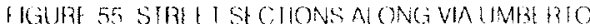

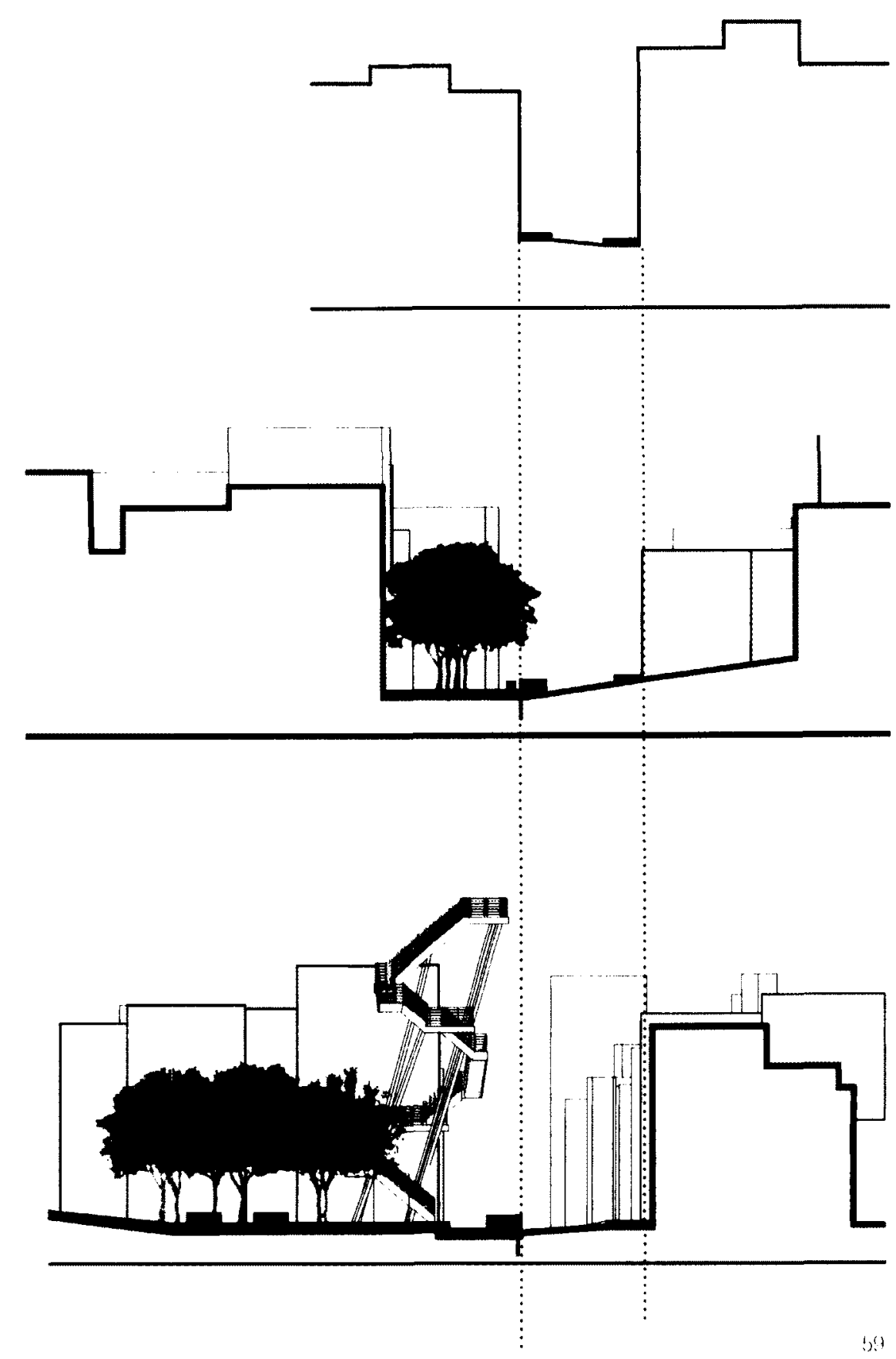




\section{TOWER DESIGN DEVELOPMENT}

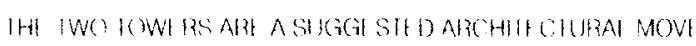

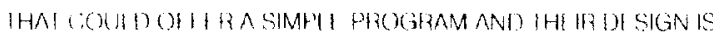
SC.HIMAKIC

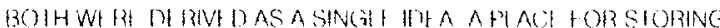

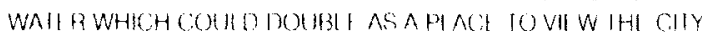

likt IC.H 1 |

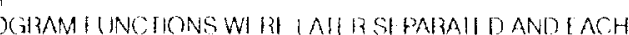

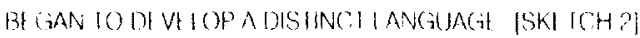

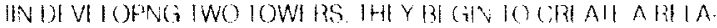
BONSHIF' WIIH I ACHOIHI RAND IHF HIA ZLA IHAI I NCOMHASSS

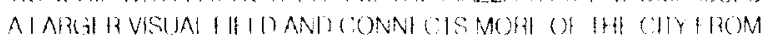
ONI IOWI BIOANOIHI IA
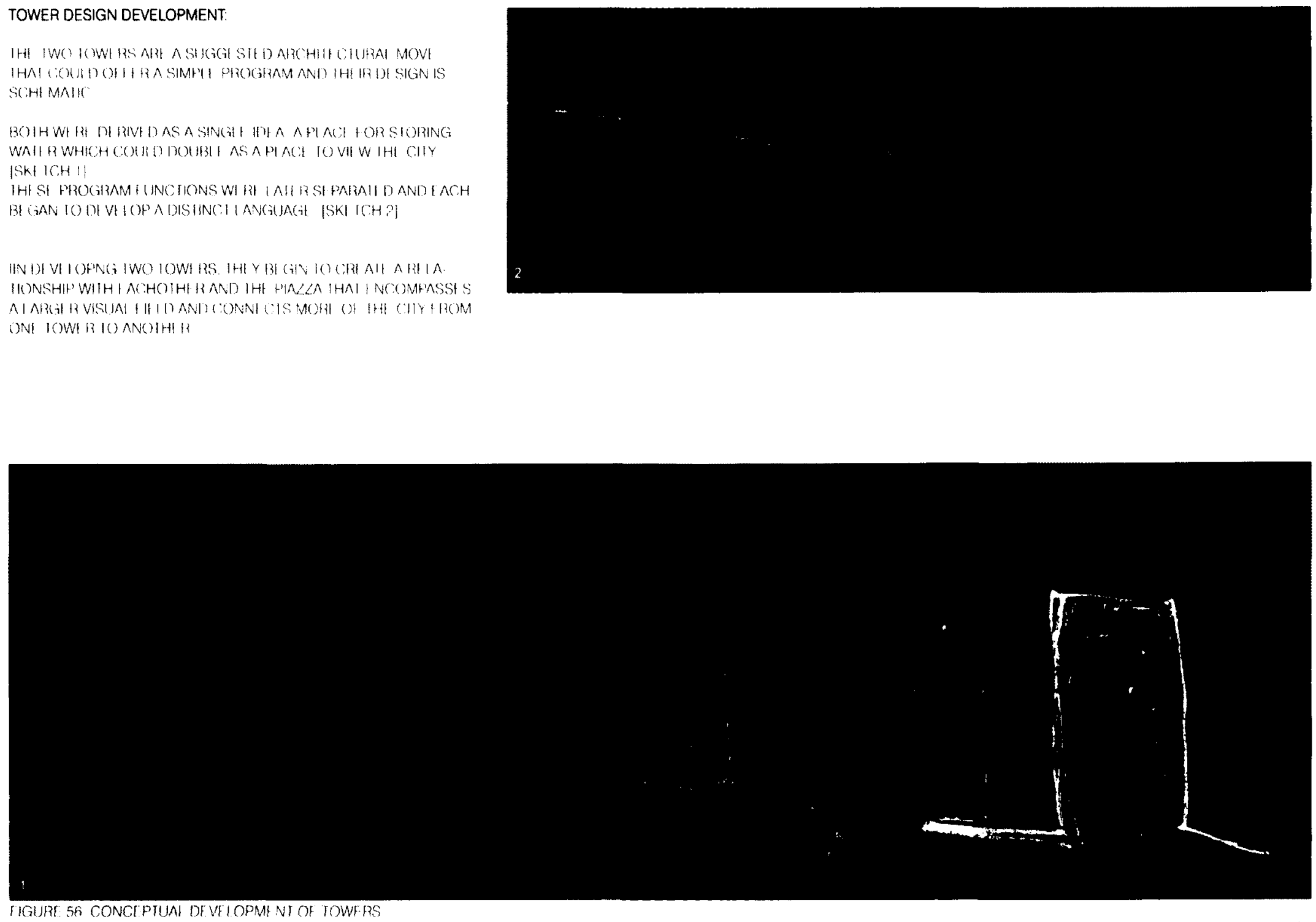
a I O ng VIA UMBERTO

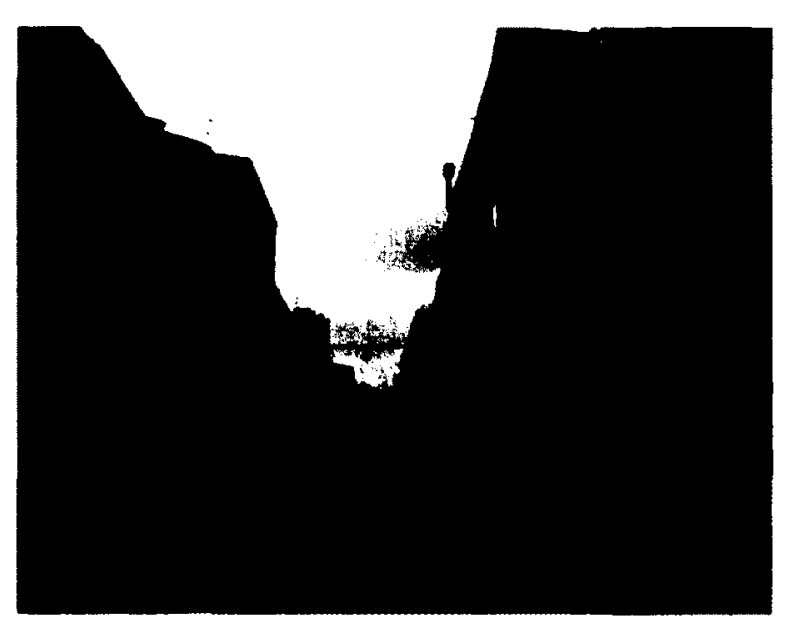

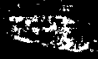
24 + 15 

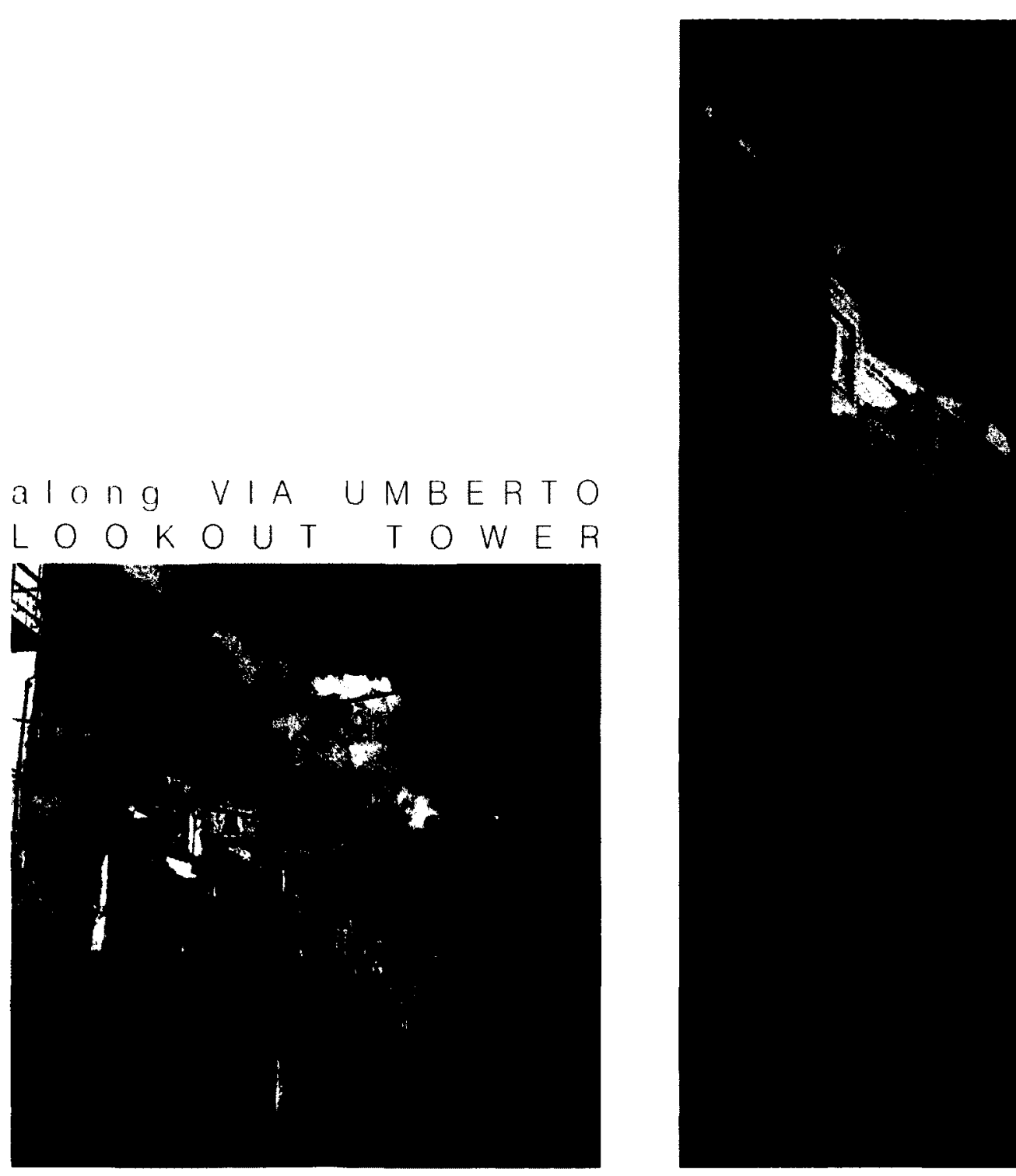
$V I T T O R I O$ EMANULE W A T E R T O W E R

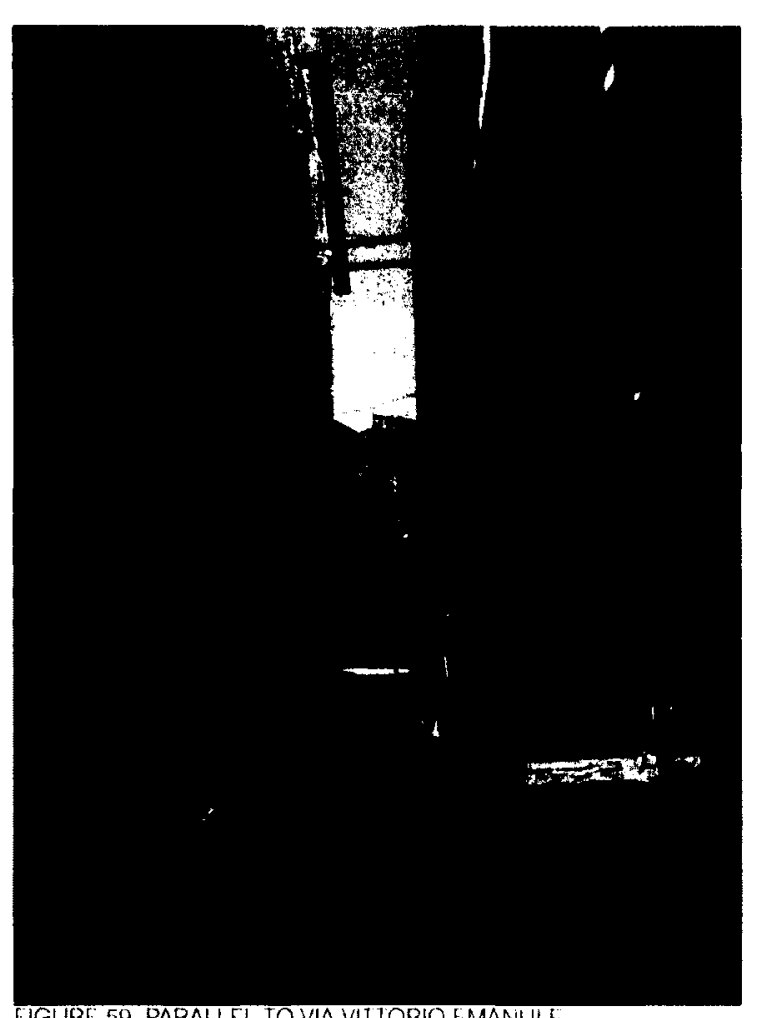

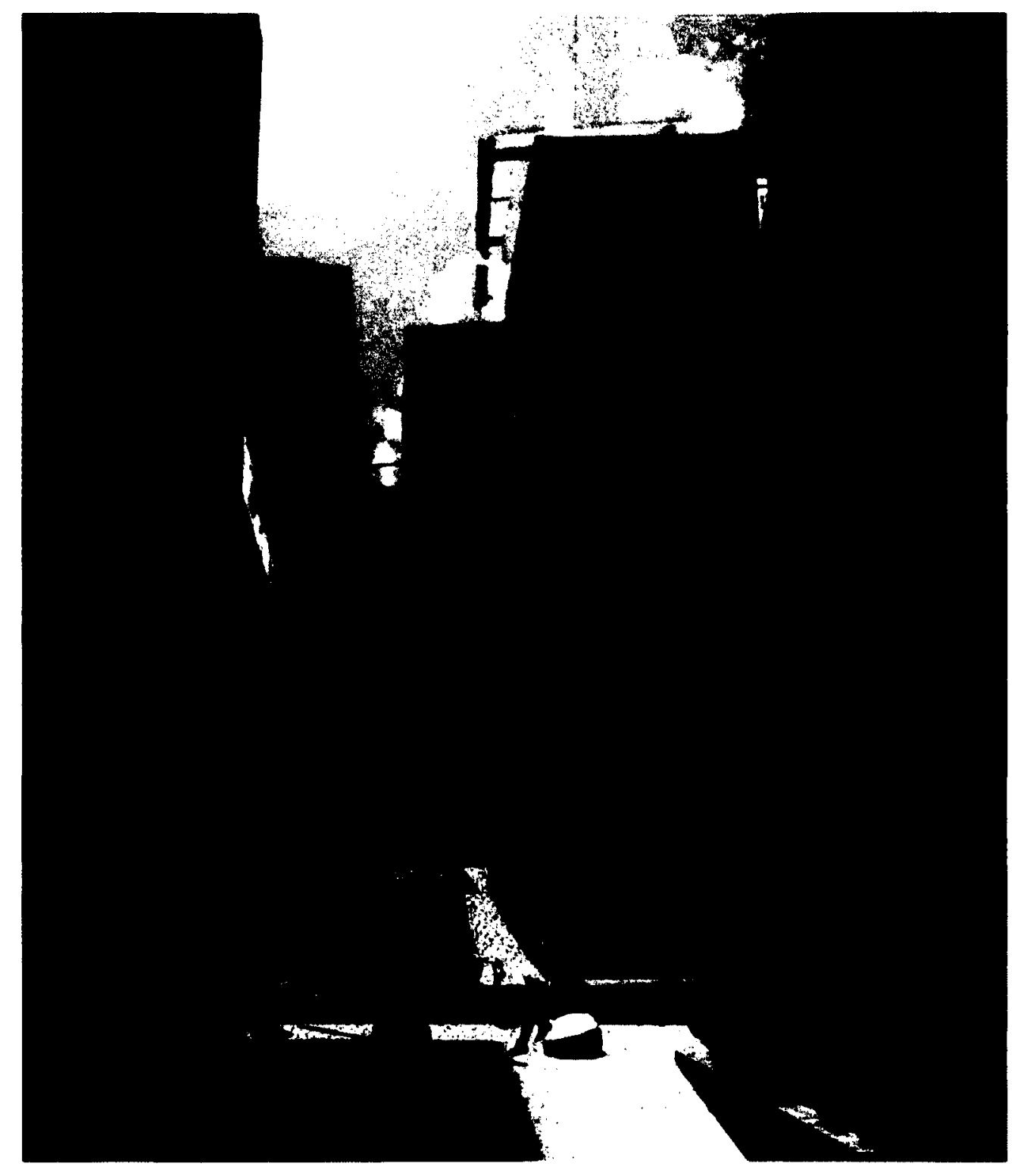




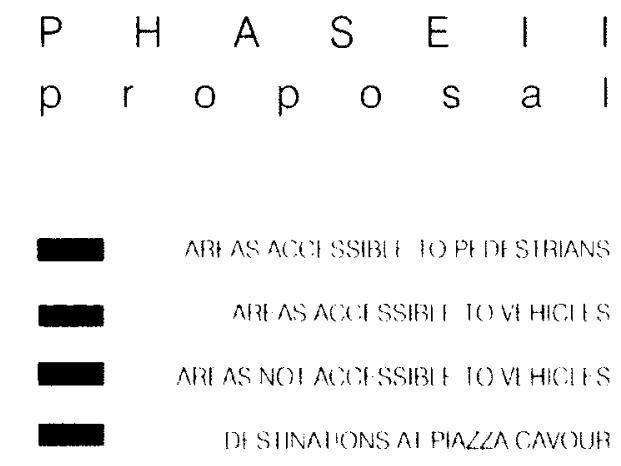

[PHASE II - PIAZZA DESIGN]

IHI PINZLA IS DE SIGNI D WITH MAIORF AND MINORSPACFS IHESF ARK INSCRIBE D IHROUGGH A CHANGE IN MAII BIAISAND PIANIING

IHI MINORSSPACIS IHF CORIIII OHHIZ GMAI INIIMAII ARI AS WIIHIN IHI VASI OPF N SPACF OF THE PIAZZA

IHF MAJOR SPACI SARI OPI NANO I RFF OI OBSIRICIIONS IN OROTR IO AIIOW FOR VARIOUS ACINIILS SOUINT OID

IHE WAITRIS RELENTRODUCID INIO IHT PIALLA THROUIGHANI W TOUNIAN DH SIGNE DAS A SCUI PIUIFE AS WII ASA WAIERIOUNIAN II IZ MAINS AS ASYMBOL IN IHF PIAZZA IVEN WHIN IHI RI IS NO WATER IHE IDGES OF IHI HOUNIAIN F OLIOW IHI SLOPF OH IHH PIALLA WHE RILAS IHI IOINIAIN ARI AIS DROPPED SOIGHIIY. CRE AIING GDGES AI VARIOUS HEIGHIS IOR SITIING ANOI I AN ING ACCI SSED I ROM AI I OULR SIDES IHL IOUNIAINI NCOURAGI SPF. OPHI 10 F NTI R WIIHIN II ANO GI I WE 'I WATI IOR IHE IOUNIANN IS SOUARCL D ROOM IHI WATI R TOWER

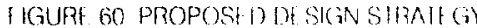
PHASE IIPIAN

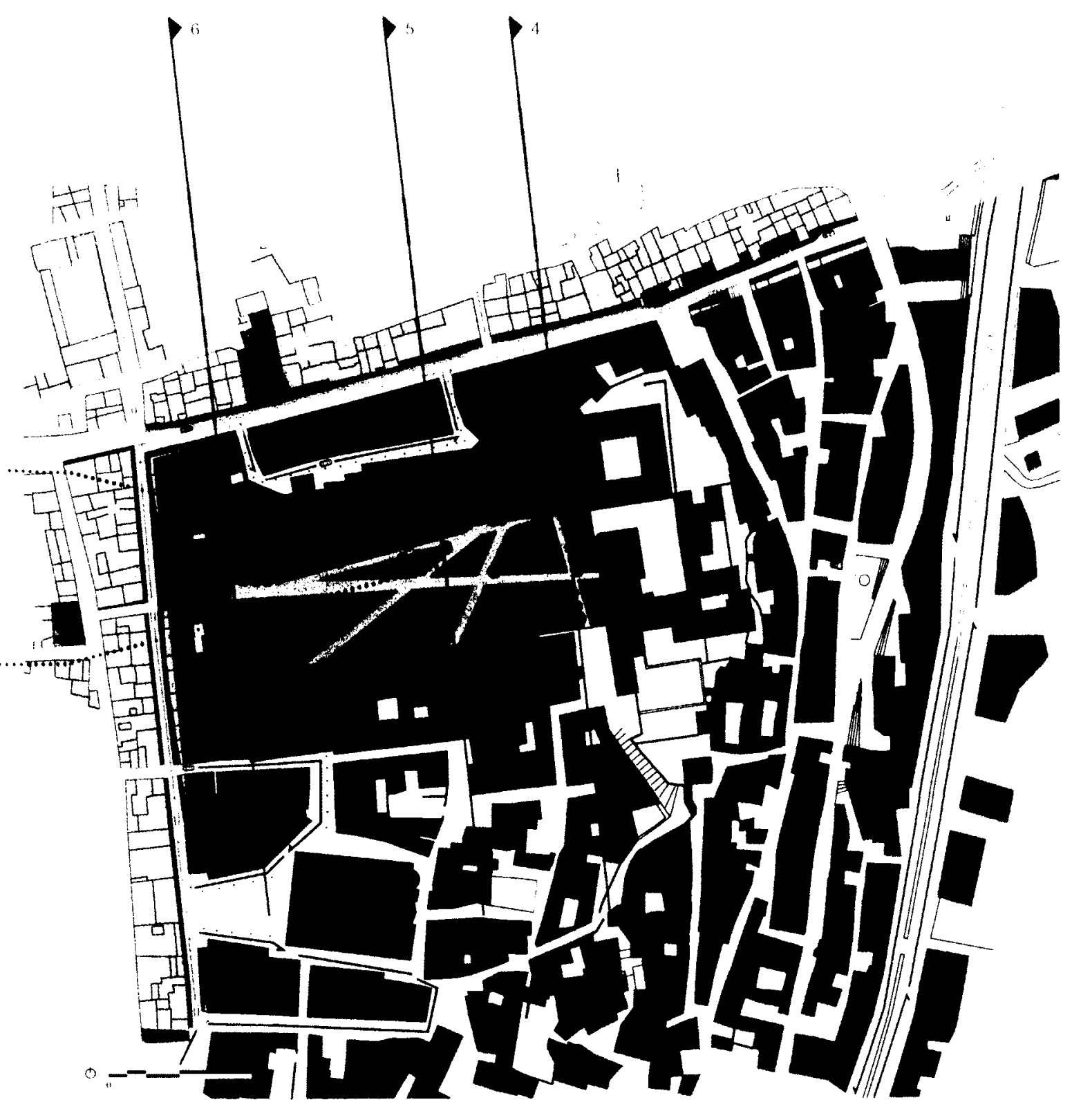




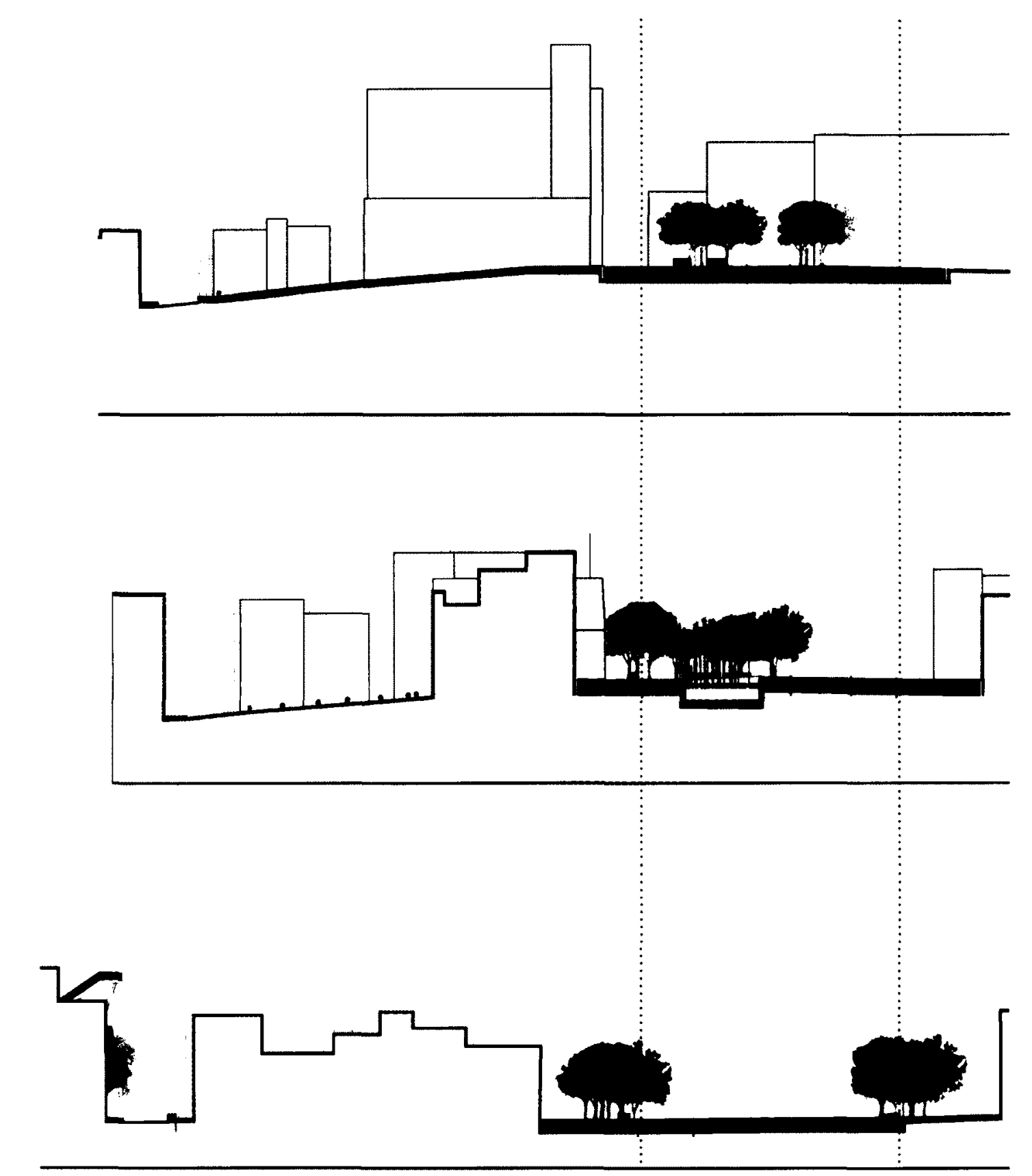

A

FGUAP GI SI CIKONS IHHZOUGH PINLZA 


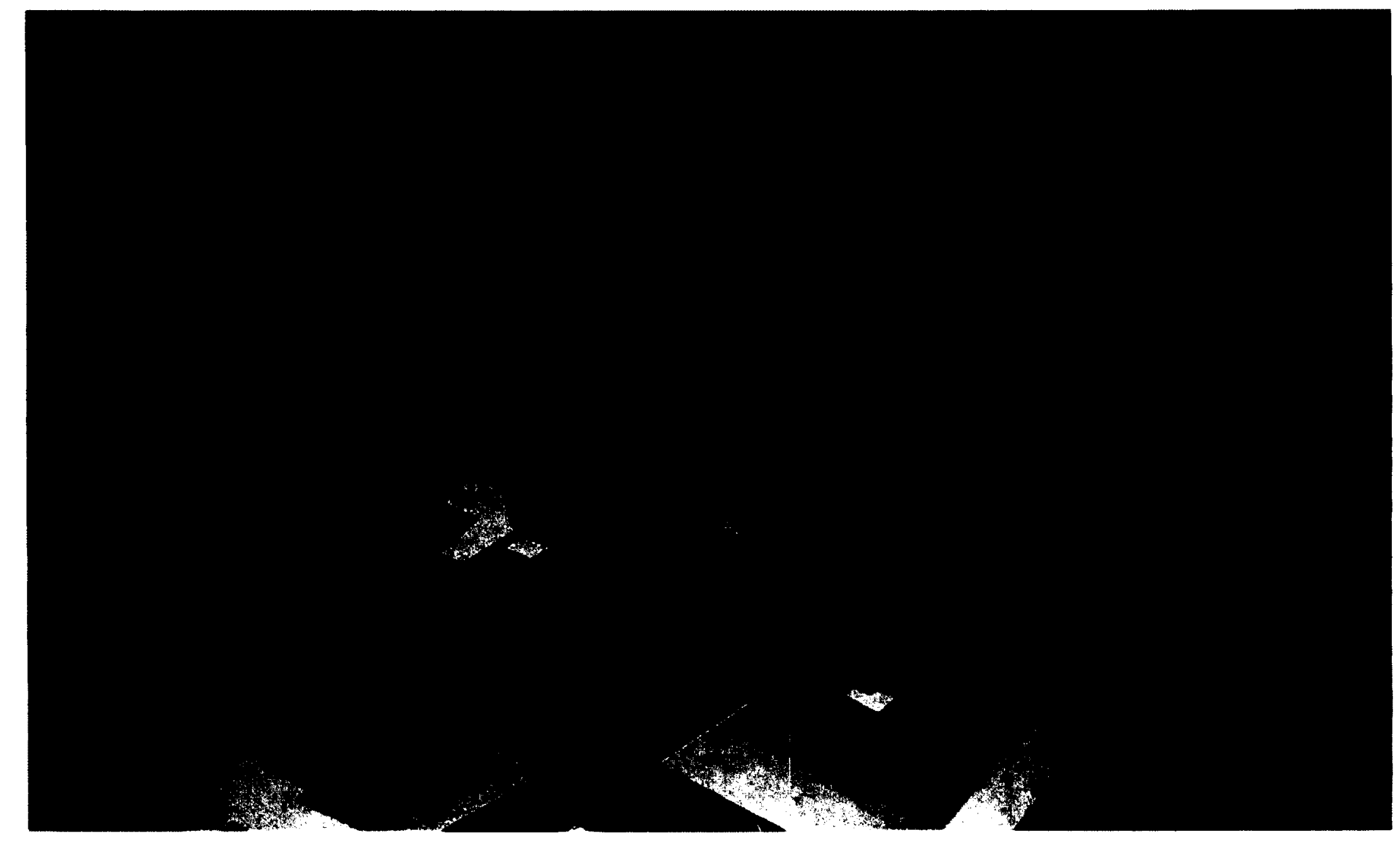




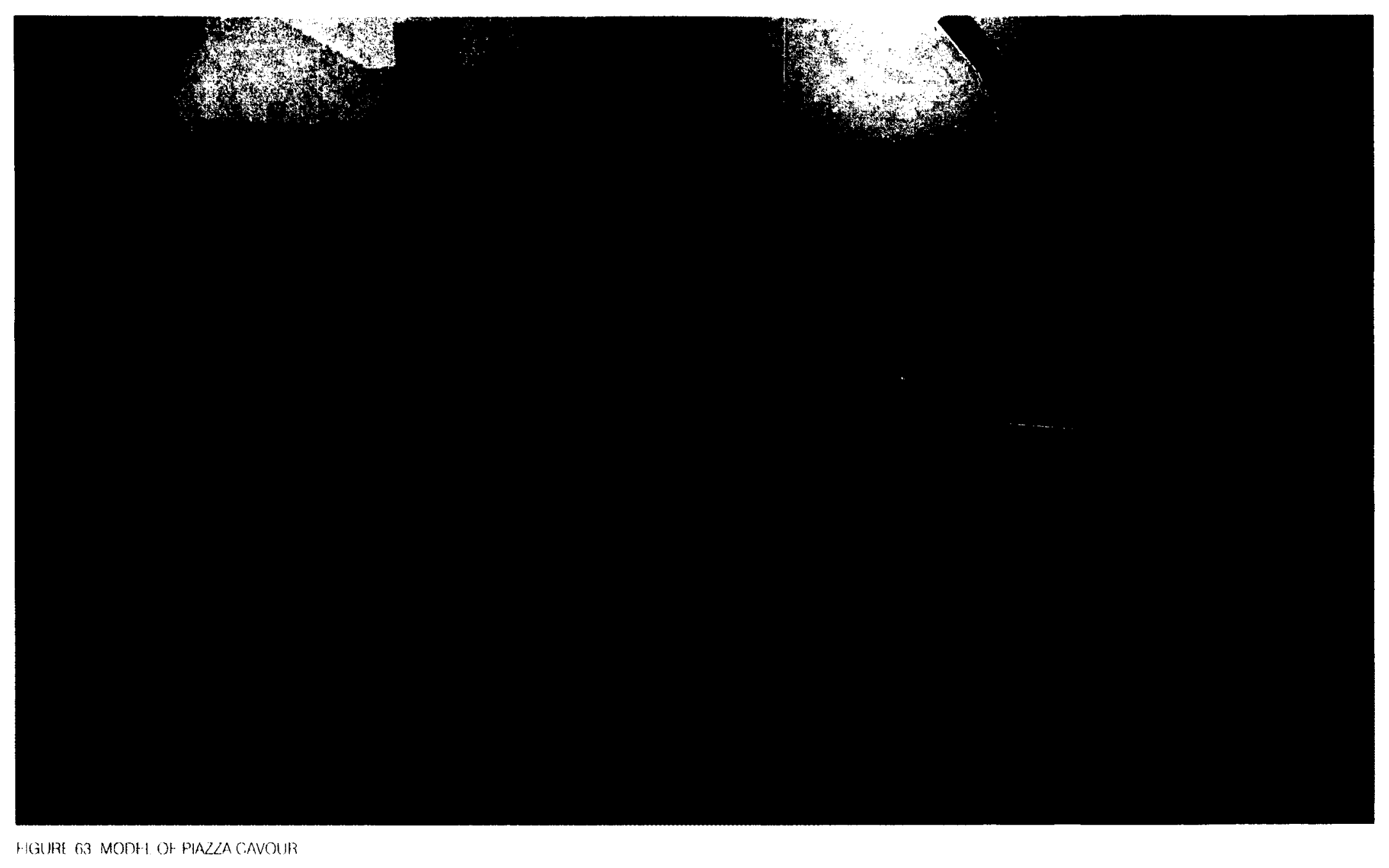





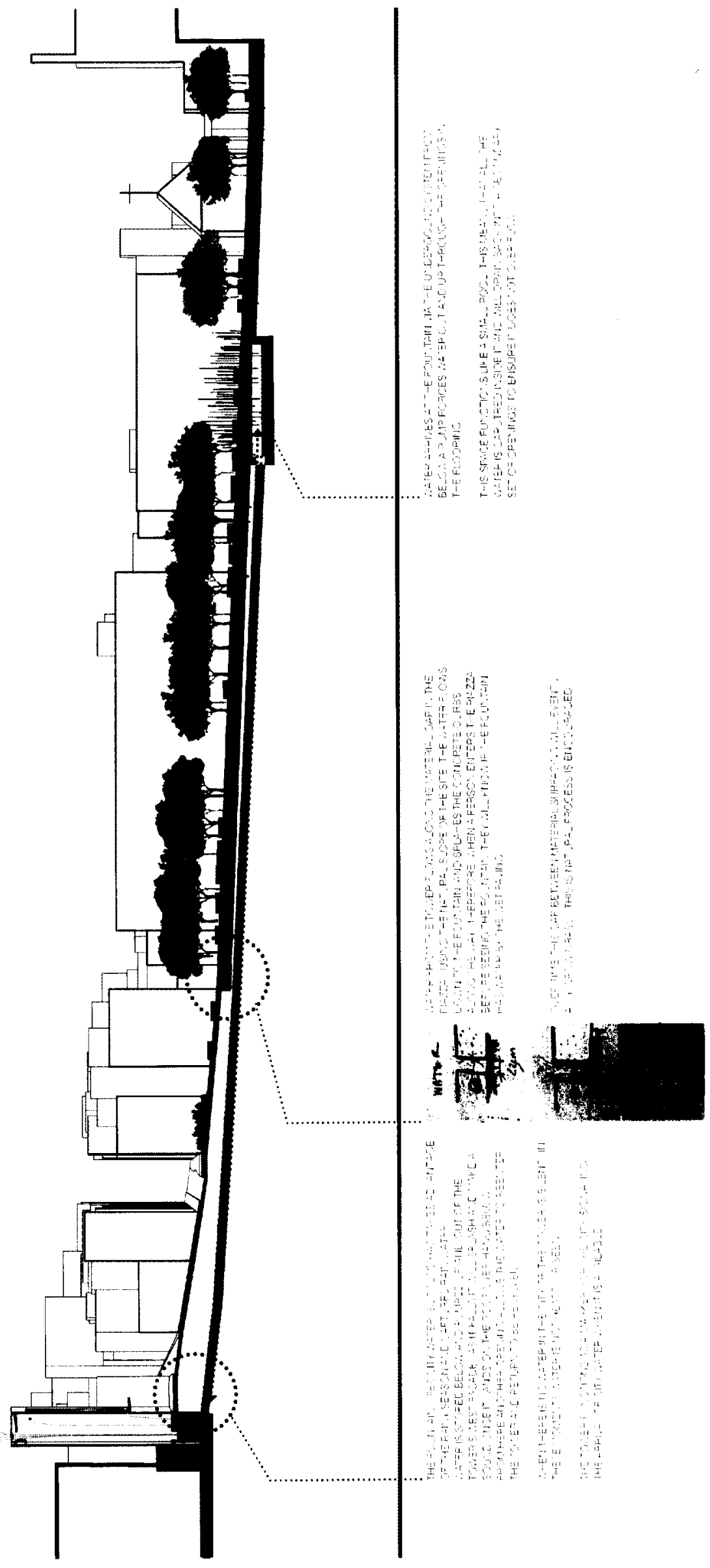




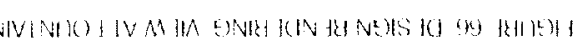

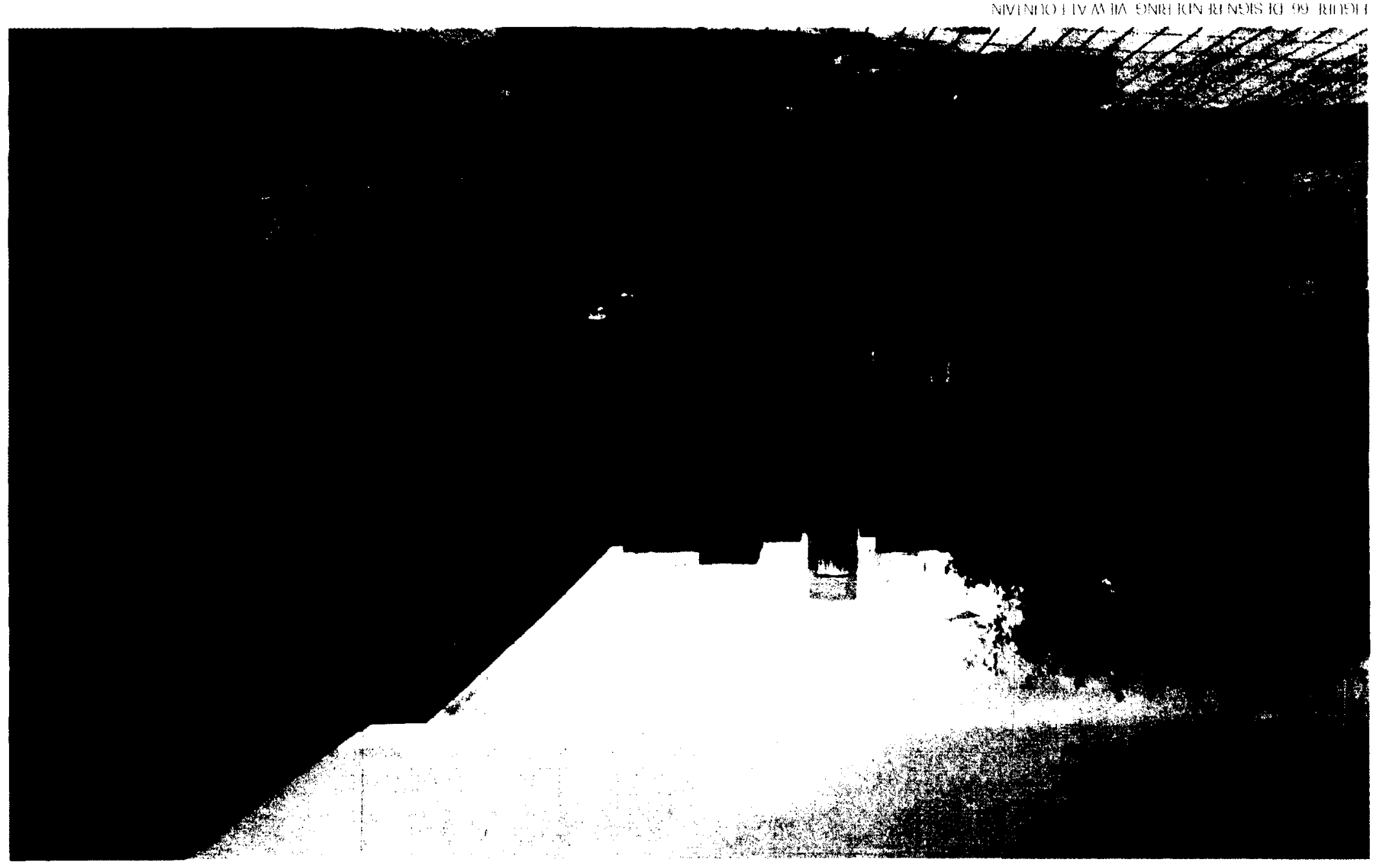




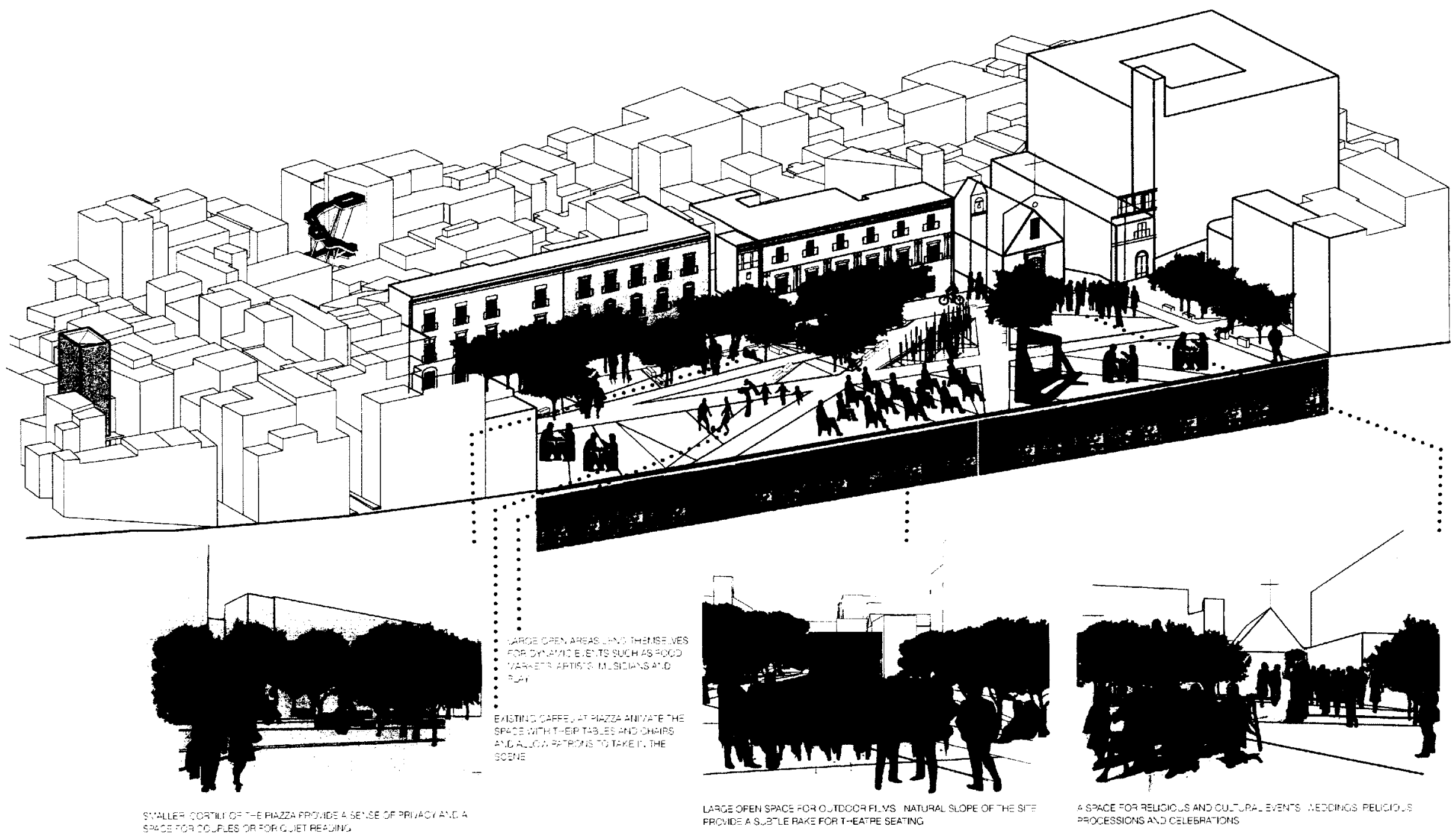

Fig GPE G ACTIVTTESAT P:AZZA CAVCJR 


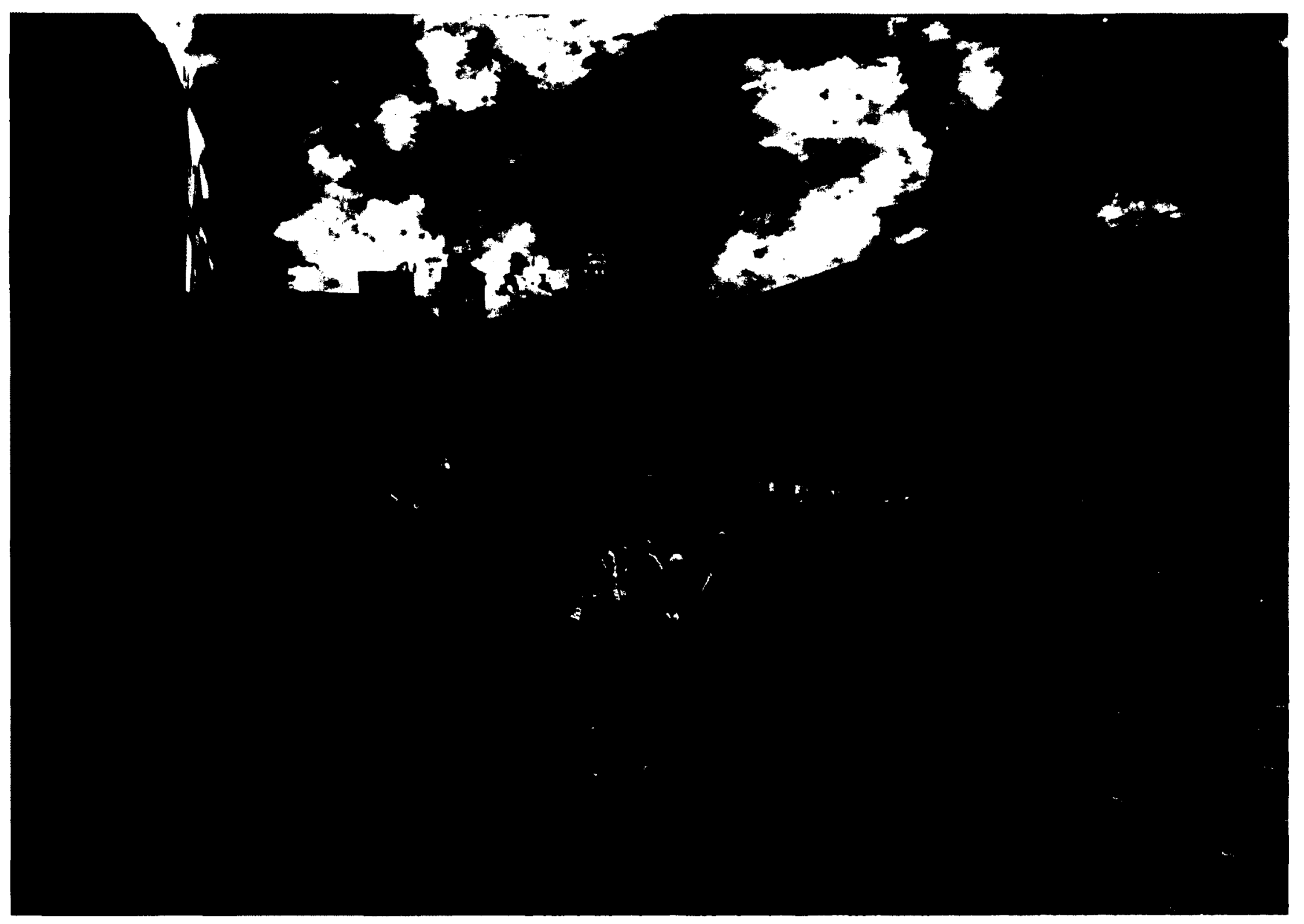




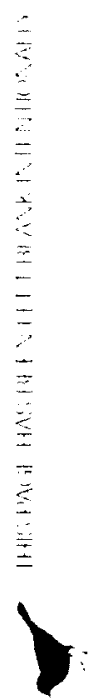




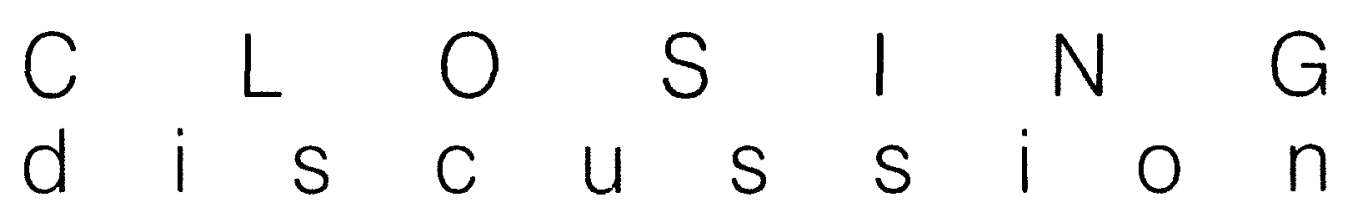

The issues underlying this architectural research proposal are a crumbling and neglected historical city centre dated in Favara, Sicily, a desolated main square; Piazza Cavour that no longer serves as the central space in the city and a recent grass roots movement aiming to reignite and preserve this area from local demolition. This thesis was born in reaction to the motivation demonstrated by these locals, who lead me to consider whether their connection - that is; their social roots to the city were a critical element needed to reinvigorate the abandoned city centre.

The framework of Social Rootedness taken from Sociology was used to rationalize the collective behaviour they engage in. Using the concept of Genius Loci, "the spirit of place" taken from Norberg-Schultz as well the value of recognizing the 'being' of a space captured in the process of building as outlined by $M$. Heidegger, allowed me to explore and uncover the meaning of the space, the value in having an attachment to place how this was reflected by the internal changes happening in Favara.

The methodology for the thesis used a mix-method qualitative approach to explore the research questions and propose a culturally relevant architectural-urban design rooted in the city's past and present urban and social issues. These methods occurred in three different stages: first it was a short term field residency and interviews with members of three grass root organizations, using open ended questions. Second, an urban analysis of the city's social and public spaces and urban movement were mapped to better understand the city's social realm. Finally, a site visit and brief survey of a sample of local residents were approached regarding the possible futures for Piazza Cavour.

Considered to be fundamental to the Italian urban fabric and it is a common feature of the European urban landscape, the piazza was chosen as the focal point for the design proposal. The piazza is an open space that connects the streets and the surrounding zones, typically the centre of the social life. It has served historically as a gathering space, as a religious venue, as a market place and for political, military, nobility and political purposes. However, the empty and desolated Piazza Cavour signals its loss as a social meeting place in Favara. 
The design proposal for Piazza Cavour and its connective tissue resulted in a two phased design strategy which targeted three social and urban issues revealed through the research. The themes considered in the design were white zones in the city (demolition sites), Favara's paradoxical relationship to water and the value of public space. The first phase tackled the connective tissue of the historical city by prioritizing the human scale and foot travel to the centre and piazza. Two nearby sites of 'abandoned potential' were also addressed in this phase through the schematic design of two pavilions. In the second phase the piazza was resigned as well as its connections to nearby arteries. Within the piazza an interactive fountain design was presented. The fountain offered itself as a water feature but also as a sculptural element which makes a statement regarding water shortages in the city since it is to remain dry when there is no water. The proposal contains elements that surfaced in the research analysis and reflect the collective memory of the Favaresi.

Finally, the development of a design proposal can be an enriching co-creative process in which the voices of a community, urban planners, architects and historians are integrated. This study demonstrated that the revival of a public space, in this case Piazza Cavour within the historical center of Favara, Sicily, must be connected with the spirit or genius loci to make it relevant to the habitants that dwell within it. The architectural-urban proposal focused on the piazza and surround area by responding to the issues the 10cals expressed and those tied to the city's past and present struggles. It did not rely on potential business or commercial activity, although these were cited by the locals as necessary for the historical centre. These were not addressed in the design since businesses can open and close, leaving the city with vacant areas to fill. The intention was to address the existing spaces and their role as healthy, attractive and accessible public spaces in the hopes to reestablishing the area to make it an attractive destination people frequent even if they do not purchase or consume anything. Instead project's greatest ambition it to create the habit in the locals to return to this part of the city and once again dwell within it. A great public space should be a comfortable sitting space from which they can watch city life unfold and in doing so take part in that scene. 


\section{$\begin{array}{lllllllllll}p & o & s & t & s & c & r & i & p & t\end{array}$}

This research and design project aimed to reintegrate the historical centre of Favara within its larger urban context; a vital and necessary task in order to conserve the existing and growing energies of the locals. The locals proved to be socially rooted to their city and acted as a result of their attachment to Favara. As catalysts of changing social and cultural spheres; they are beginning to offer the city vast opportunities for locals to return to the historical centre. Their work and motivation embodies the spirit of the Favara; the genius locus from which the design proposal aimed to reflect.

In the phased design strategy, the intention was to attract its residents to return to the historical centre, specifically to its social core: Piazza Cavour. I wish to stress that despite the design specificities of each phase, the most important element was to create a strategy which could offer a "tabula rasa"; an open space upon which various activities can unfold. In this way the locals claim the space as their own and begin to define its new identity. Furthermore, this allows the residents of Favara make the piazza a destination prior to the arrival of any businesses. This empowers them as authors of the space and ensures the vitality of the piazza as businesses will come and go. The most challenging part of this design exercise was to gage how this urban-architectural strategy could generate a new habit in the locals; to return to the centre. Knowing that they are the key element in generating change in the city, the design had to appeal and respond to their comments.

Similarly, the local government ought to consider the collaboration of its residents within their planning process. Within this thesis, both the theoretical framework and field work highlighted the locals as a primary tool for reigniting the historical centre. Public participation in urban design is the norm in much of North America and also Europe; an initiative Favara has yet to incorporate. In addition, the municipality continues to address urban planning through technical officials rather than through a task force of urban designers, architects and planners which outlines the root of its urban dysfunction. Members of FARM Cultural Park, NICODEMO and Sicily Foundation could enlighten city officials because they are rooted within Favara's social and cultural networks and have an intimate understanding of what locals desire for Favara. The municipality has an opportunity to 
learn from these individuals and go beyond what the Italian Planning Act requires them to do; simply present the PRG (municipal urban plan) to residents before the approval process. Currently, Favara is undergoing a process of social and cultural change which is being lead and inspired by these local organizations. They are taking risks and exploring the city's urban issues with creative initiatives that target city residents. It is time for the municipality to recognize their efforts and contributions to the city and begin to work with them if they wish to salvage and strengthen what remains of the historical centre.

Without implementing a project, it is often difficult as a design student know when it has been successful. However, the opportunity to do first hand field work and live on site rarely occurs in an academic design exercise. I can attest that in having established myself within the social network of Favara's active locals and participating with them in the summer of 2012, this design project responded accordingly. It was my task to learn what Favara was and what it could one day aspire to be. The potential to learn from a community via participatory design is frequently commented in architecture, however my experience and the subsequent design project was about learning a city and its residents prior to proposing a design solution. It was not possible to sit and draw with the locals regarding all aspects of the design; instead they guided my work through the comments and opinions they had shared with me.

Finally, this project revealed the authority that field work results can impose on the process of design. The methodology used in the thesis exploited personal knowledge of the city, interviews, surveys and urban analysis. The process allowed me to target specific issues in Favara and propose solutions rooted within fieldwork responses. However, this did not bind me as a design student; instead it informed me and provided me with the appropriate tools. If an architect is address the issues of a site authentically, they must go beyond the academic exercise of urban mapping and connect with the local organizations that are targeting the same issues. I believe that only in this way can an architect be fully informed and approach the task appropriately. I wish to stress the value of this learning; since it not only informed the project and me, but also the locals in my interactions with them. As the various grass roots organizations in Favara grow stronger and broaden their scope, I hope the city can begin to recognize the ways in which they are changing the Favara and make them a part of the process. 


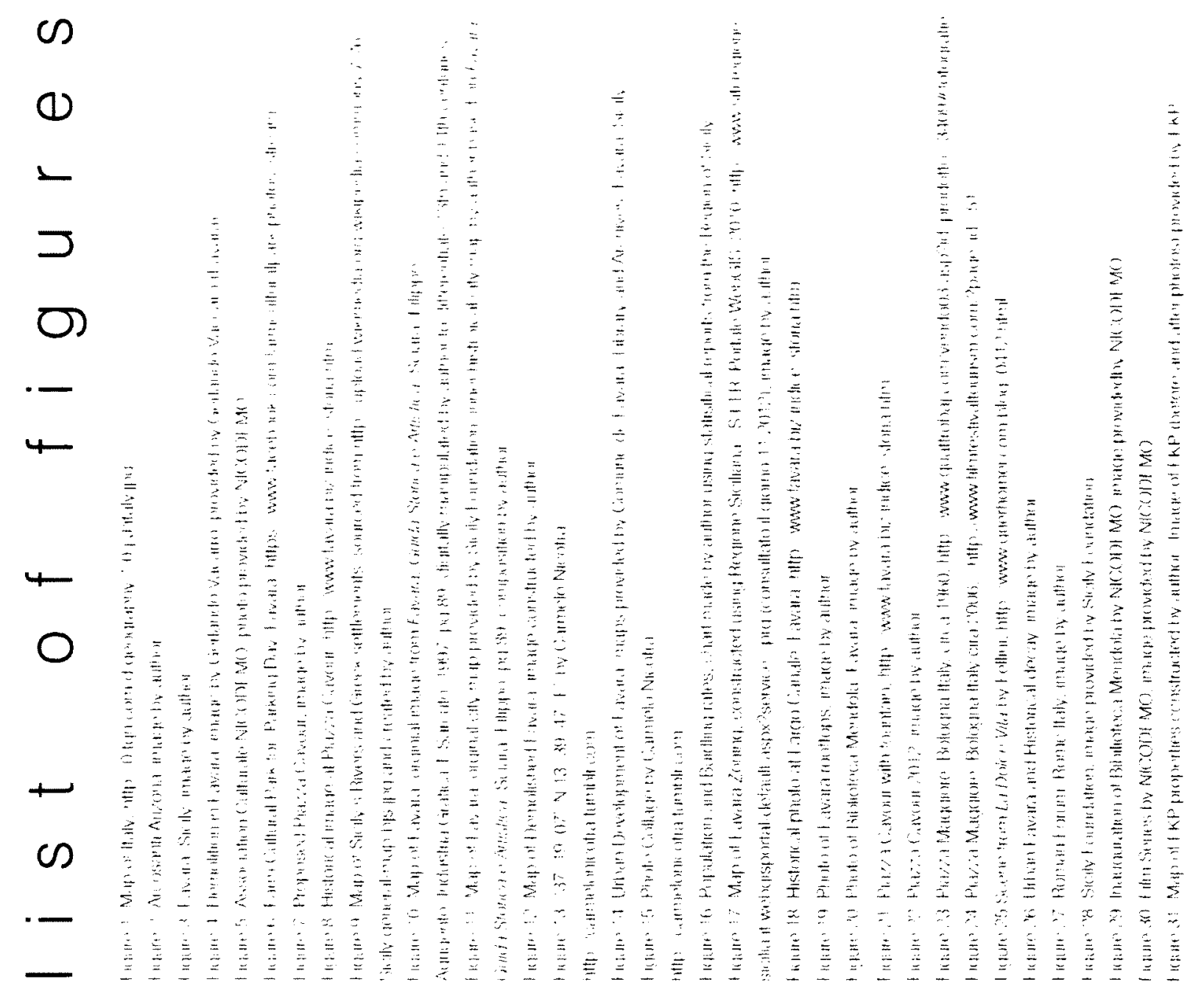




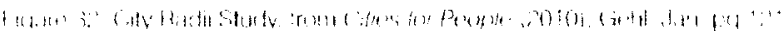

the

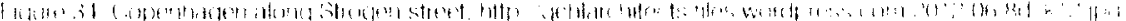

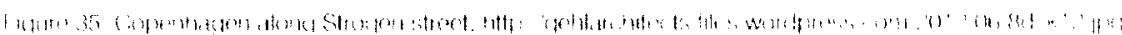

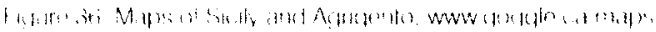

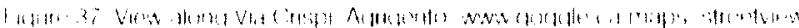

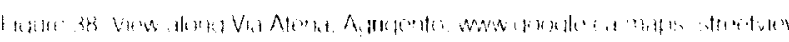

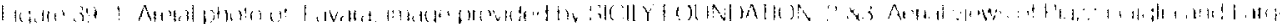

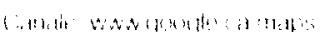

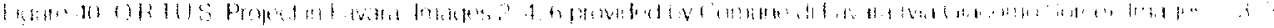

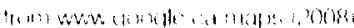

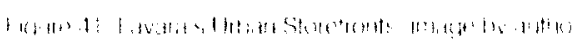

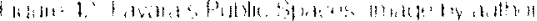

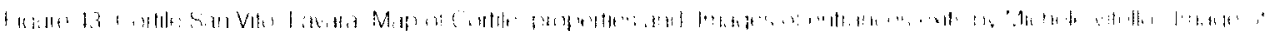

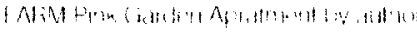

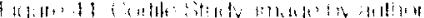

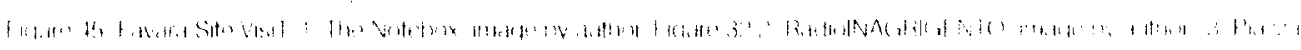

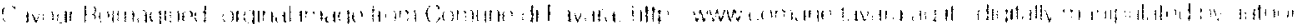

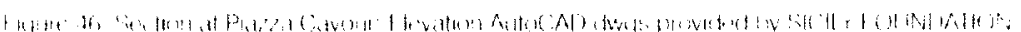

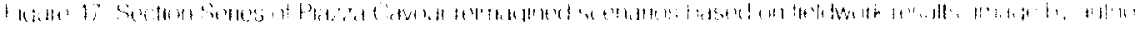

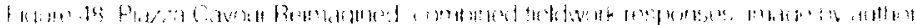

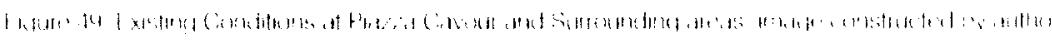

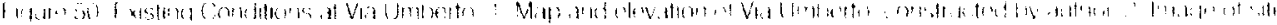

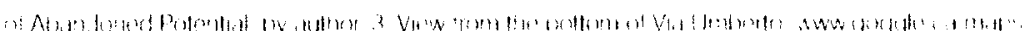

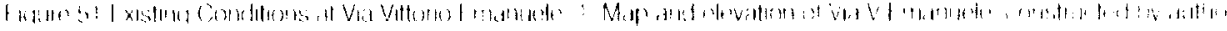

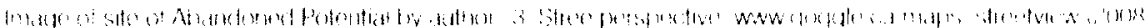

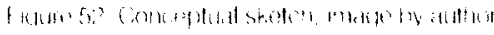

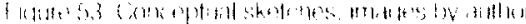

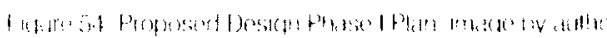

f 16 :

I le:

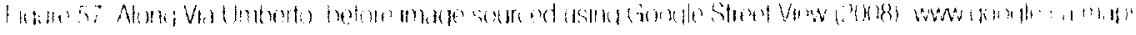

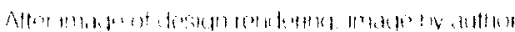

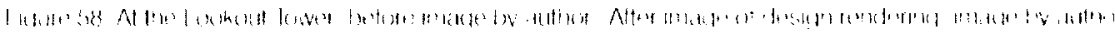

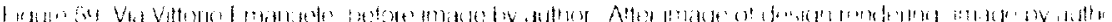

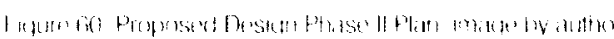

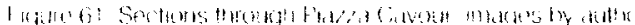

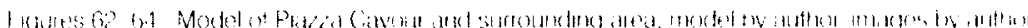

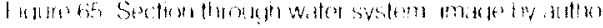

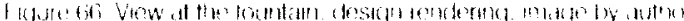

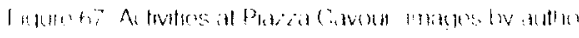

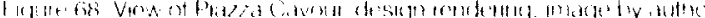




\section{$\begin{array}{llllllll}A & P & P & E & N & D & I & X\end{array}$

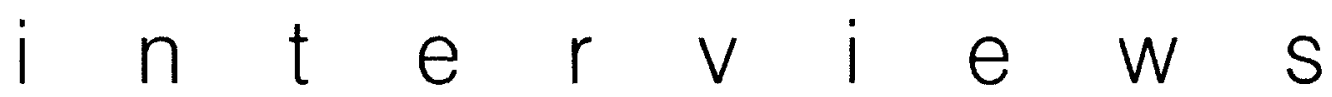

All interviews were cleared by the Research Elhics Board at Carleton Universily profect 13-0330 entitled FARM Cultural Park: The Making of a Commumty. 
ANDREA BARTOLI [AB]_Founding Partner of FARM Cultural Park_July 22, 2012 [interviewer Natalia Woldarsky Meneses (N)]

$\mathrm{N}$ : Where does the name FARM come from and why is it still important to the project today?

$A B$ : The name was born 10 years ago, from the Farm house at Butera, my family's home which was once a Farm. At that time I did not know what to expect, but I knew that I wanted to create a space that could host artists, that it could a factory for ideas then, years later FARM-coolhunting. FARM-youngart, FARM-design were born and eventually FARM Cultural Park

N: Would you consider FARM as a brand or sorts?

$A B:$ Yes

$\mathrm{N}$ : What is the relationship between Butera FARM and Sette Cortili (7C), aka FARM Cultural Park?

AB: Butera is the nucleus, the mother sort of speaking, it was the first place where we hosted artists, we have learned from our experiences there in order to make FKP better. It will continue to be used as an experimental testing site for us.

$\mathrm{N}$ : Before work began at $7 \mathrm{C}$. was this a place you used to go to?

$A B$ : No, before we were here it was a dead space; there was a lot of crime and garbage

$\mathrm{N}$ : Why was $7 \mathrm{C}$ chosen as the site for the project?

$A B: 7 C$ is a totem for Favara, a symbolic place for the city except that no one was living there. I never imagined such a space. I believe in destiny in a certain way, I was looking for place to create my own studio, some artists spaces. We found $7 \mathrm{C}$ and it was affordable; we paid 50 000euros for all those spaces, it was affordable and we could do so much with very little.

N: How would you describe what FKP does?

$\mathrm{AB}$ : We host big events and small events, other times there is complete silence there. We are still not a mature and organized group. It's not out of snobbery, but it is clear that this project is not for everyone. A daily schedule is still not organized, but it is not there to support a daily program. We have things to sort out, such as the new kitchen

$\mathrm{N}$ : What future do you see for FARM, what do you wish to see?

$A B: I$ hope it can extend beyond $7 \mathrm{C}$, father into the historical center and attract people so that they will promenade and enjoy the spaces, it is after all an attraction space with so much to offer (culturally), it's about tourism. Attracting tourists is a way to give Favara an identity, increase tourism, and out of my own personal pride. I have seen so much grow out of it, such as the kids from NICODERM, they have really learned something from it.

N: Which is the network within which FPK operates?

AB: Our larger network is fragile; but we are connected here with folks like NICODERM, Michele Vitello (architect), Giacomo Sorce (architect), the owners at the BelMont Hotel. But the most important connection we need to make is frail, that is, the one with the municipality and government bodies within the region. Within these last two years FKP has played a central role, what is happening here doesn't happen in Palermo for example or in other big cities. In a way we have created a new category; it's the first cultural/tourist center. When I think of the opportunities it creates; of the children who participated in the statue workshop for example, and all the other workshops they will participate in, the international influences and encounters they have, this will change them, it is them who will change FKP in the future and who will change Favara. One thing I am very proud of is that people go to FKP to take wedding photos; we don't advertise it but I think it's pretty cool that people come in this way. I am proud when I talk to young people and they are proud of the place, this makes me happy, of course there are some spaces that have more energy than others. 
$\mathrm{N}$ : How do you see project growing in a way that is more sustainable? Where is it not resting on your shoulders or coming out of your pocket?

AB: All the new spaces we make, like the garden and kitchen, the idea is that one day they will make money, of course this is the idea. This will depend on how brave we are; I am the limit and the control of this project, the reality is that I am very much the economic power, cultural connection and extended network. I hope that as it grows, I am able to release some of these duties.

The first opportunity we have to create a social difference for the low income groups, we'll do it; but it needs to be nurtured, developed, it must be formed into them. Development of this sort of growth will give them something else, it will take at least one generation.

Everything comes as a surprise. For example, I never expected a Canadian masters student would come one day, but here you are! I'm proactive as to what needs to happen, I can reflect back and see that we only started 2 years ago, and yet we have done so much. And we have a lot of fun. Favara was cheap and it made my dream possible, it was destiny like I said

$\mathrm{N}$ : You mentioned the younger generations as being keystones for the future of FKP, how are you finding the integration between old and new generation inside $7 \mathrm{C}$ ?

AB: Its already a miracle that we get along, it has been a slow process, however I know that when these old ladies begin to die a part of the project will go with them. They are a part of it. But we also look to the future and are looking for ways to open up programs to younger generations.

ARMANDO GIGLIA [AG_Employee at FARM Cultural Park_July 25, 2012 [Interviewer Natalia Woldarsky Meneses (N)]

$\mathrm{N}$ : How long have you been working with FARM Cultural Park [FKP] or its founding partners? Was there a previous relationship with the partners of FARM? Did they find you or did you seek them for work?

AG: I have worked for Andrea for 3.5 years. He contacted me when he was looking for a person to do communications and web development. I began with working at his office (notary office) doing graphic work and communications and then saw as the FARM came to life.

$\mathrm{N}$ : Was your job description clear when you began and how does this compare with what you do on a daily basis?

AG: It was what I expected. But things developed slowly. I was here when the project began so I saw it come to life.

N: How would you describe your role/job at FKP? Describe a typical day for you working with FKP. Are tasks within your job that you never expected to do? Some evening I have seen you be the barman or the cook, did you expect this?

AG: I mostly work with communication, my title is communications manager. But I also work with Andrea's business; on his website, doing graphics, marketing, newsletter. Here at the FKP I also handle these tasks, for example, I hold the FKP phone in my hand. That means that when someone calls, they speak to me. I like the diversity of my job title. Yes some days I am the barman but it will not always be like this because when FARM grows; there will be other employees, barman, cook, etc.

$\mathrm{N}$ : As you saw the FARM project develop, something that is an experiment within Favara, what did you think about it? What is what you thought or imagined?

AG: No, it was not what I expected. Our intention was to make Favara stand out, make it better. But the culture of coming here does not exist in Favara. Young people do not come, as you saw last night. Its not enough to open a cultural venue and expect people to show up.

$\mathrm{N}$ : And do you think this is something that can change, that you wish to see happen? 
AG: Yes, it will change. Yes, in any case it is already changing. Before there weren't the pubs you see now, there were no night venues. By $9 p m$ Favara was closed. The last 2 years these kinds of locations have opened and can be seen in the growth of a night life

$\mathrm{N}$ : With these changes happening, does it make you happy to be part of such a project?

AG: I am proud of it, it's something I wanted to be a part of

N:Prior to working with FKP, did you ever frequent Sette Cortili [7C]? How did you integrate with the community, if at all?

AG: No I never came. I thought it was weird as a place because the residents inside this cortile have a different culture than the rest of the world. We do have a closer relationship with them now. Initially the residents were atraid of us, they were afraid they would be kicked out, now they are more affectionate, they treat us like old friends, they way we greet each other. But its difficult to have major conversations, we say hello but that it all, it's not like we have a lot in common.

$\mathrm{N}$ : Since you work here and you see the people that come by, why do you think people come to visit FKP?

AG: Out of curiosity and a small part out of pride. Though they are not always from Favara, but usually from the province of Agrigento

N: How would you describe FKP? When someone arrives, what do you tell them?

AG: That is it a cultural, touristic, contemporary park. It's like this, a place where you can enjoy contemporary art or maybe not, have a glass of wine while you are here

$\mathrm{N}$ : What future do you see for FKP and for yourself within this project?

AG: On my part. I hope to be an active part of the project. If there is a need, I will do whatever, but I would prefer to be more active in communications than cooking. As for the project, it will begin to be more attractive to the locals. And I think one day it will be a place that will never close; it will be a $24 \mathrm{hr}$ venue. You know before FKP there was nothing at 7C. Nothing. It's definitely an asset for the young kids. They will grow up here in a place full of culture, exposed to art work and all the artists and events that come through here They will grow up differently.

\section{FLORINDA SAEIVA [FS]_Founding Partner of FARM Cultural Park_Augusi 11, 2012 [Interviewer Natalia Woldarsky Meneses (N)]}

$\mathrm{N}$ : For whom did you begin the FARM project? Why did you choose to get involved in this?

FS: Well, it never felt like a decision we made, it just sort of happened, it was almost natural. Something we had talked about for so long, we wanted so badly to make something new in the city. I could say we did mainly for us, the sake of our children.

$\mathrm{N}$ : It that what inspired the project? Or was there an event a moment something specific?

FS: No nothing in particular, we mostly wanted to have a nice place to be able to bring our children. A nice place where they could grow. At first Caria (their 6 year old daughter) hated going there. We were very busy focused on the $7 \mathrm{C}$ and we were always there. But once we launched FARM in Favara, had inaugural party, she was happy. Our goal has always been to make a little part of the world a better place, but its not just for Carla and Viola (younger daughter). The project and the energy it brings is for everyone

$\mathrm{N}$ : it there anything you would like to change, or do differently to achieve other results? 
FS: I wouldn't change anything about it, thought I would like to see it more frequented. I'd like to see more young people going there.

N: How was the transition to $7 \mathrm{C}$, was it a place you knew of before being from Favara? How did create a relationship with the residents of $7 \mathrm{C}$ ?

FS: I did know about 7C, but it was not a place I would go, I can recall being there only once. Yet once we were there, I found it easy to relate to the people there, my relationship with the residents was easy and comfortable. I was always open with them. At first there was some tension with Andrea since he is not from Favara, they would make a point of this. Eventually they got to know both us and learn that we were not interested in relocating the existing residents of $7 \mathrm{C}$. Then it was fine, we got along very well.

$\mathrm{N}$ : What role do the existing residents play inside $7 \mathrm{C}$ as the FARM project grows?

FS: For us, it is important that the few that are there, remain there. They are just as much a part of the project and we try to involve them as much as possible. We are trying to find ways to create programs that can involve them directly and that can be free for them to participate. For example, we are going to create a child care centre but before the space is ready we are beginning the children's workshop with an after school language program. There will be an enroiment process but the program will be open to all children where we will have English and French afternoon programs.

$\mathrm{N}$ : What would registration involve? Is there a fee?

FS: yes, they we will consider to subsidize those families who cannot afford it. The program will be hosted by FARM, as a ways to give back to Favara. in this way FARM can be more inclusive of the city.

N: How would you describe the project at $7 \mathrm{C}$ ? And what is term vision for $7 \mathrm{C}$ and FARM?

FS: Well, first, l'd like to see the historical centre lived in, lively and full of people. Were people walk around from one place to another, always on the streets, the way great cities are. that's what l'd like. FARM Cultural Park, well, our website says it's a cultural touristic park, but that's not actually true because few tourists go. Generally speaking few people go. but that does not mean it is not happening or on its way to being something great. It's a bit like your first ultrasound. All you hear is murmuring. the slight sound of a heart beat and the faint light you seen on the screen that flickers. FARM is like that, right now it is only a slight murmur and flickers of light. But just like a child, it will grow. In 10 years that what I would like to see, l'd like to see it grow and mature

$\mathrm{N}$ : That's lovely, I have found that people working with FARM or close to all seem to have a different definition for it I guess because of what it means to each person

FS: well yes, it is actually very hard to define what it is, or what we do. Everyone that cares for it sees it differently, you see it as architecture, artists seeing as an experiment, others as theatre space, as a music venue, dance space, it is different for everyone yet it has an identity among those who care for it. A very clear identity. Yet it is capable to being so many things, it can lend itself to others for anything, that's its charm

\section{VINCENZO CASTELLI [VC]_President of Siclly Foundation and Lead Architect for FARM Cultural Park_ June 26, 2012 [Interviewer Natalia Woidarsky Meneses (N)]}

N: How did you begin working with FARM Cultural Park [FKP], with Andrea?

VC: We met Andrea in 2002/3, did house design for Andrea and Florinda, our relationship has always been a friendly one. I began first with the design of the patio and pool at Butera project; an 'albergo artistico'

Then I brought Andrea to Sette Cortili [7C] to show him the site, suggested that he move his project to Favara, that it could receive more attention there than in the rural peripheries of Butera.

$\mathrm{N}$ : Working as an architect for such an experimental project, what do you have to say regarding community involvement, collaborative and/or participatory design? 
VC: FKP has a long way to go. Of course we began just me, Andrea and Florinda. I have been working closely with Andrea from the start, when we began most of the neighbours did not know what we were doing or what was happening inside these spaces. There are some residents that have lived here forever: it is a micro social system. When we began, a presentation was made for the people of $7 \mathrm{C}$. there was some resistance. See, it because FKP creates a paradox, the people that live here live in cultural poverty, have no knowledge or education of art and design, yet through this project they have come to appropriate it as their own. Since they have been involved from the start, they know about the materials being used, paint colours, design process etc

$\mathrm{N}$ : How is it working with all these residents, and all their opinions?

VC: You take the opinions that matter, not because you feel superior, but because there will always be opinions

N: Are you paid for the work you do?

VC: No, I am a volunteer of sorts, I have my office here but I do my own work for private clients and work with Andrea and Florinda when there is a project happening here. I continue to work as the "FARM Architect" because I was here from the beginning. When we work is it quickly and spontaneously, we know each other well and we manage to arrive at an agreement quickly.

N: How do they compare as clients, say with other projects you do?

VC: I don't see Andrea or Florinda as clients, but as partners. I don't consider the work I do here, as "work", for me it's breath of fresh air compared to the other projects I do with home owners.

$\mathrm{N}$ : Where does the funding for the project come from for FKP?

VC: Mostly from Andrea's pocket, the municipality provides very little funding. FKP doesn't make money, even at the FOOD Shop, which was intended to operate as an easy cheap sandwich shop costs so much to run it, just to make a sandwich and very few people go, it's not worth it. FKP should be sold to foreign hands, it doesn't make money here. F's culture presents a different image abroad versus within Favara. Architects are taking the front seat in changing these things in culture. not other professionals, architects.

FKP has brought people back into the historical center. I have always been interested in this part of the city (aside: worked in Tunisia at one point and tocused thesis work on Favara and Tunisia, specifically social/urban issues)

$\mathrm{N}$ : What kinds of regulations or governing bodies control historical properties in Favara?

VC: The historical community board is within the province of Agrigento. They do not concern themselves with these small spaces. We have had to deal with recentiy for the childcare project that will inside Palazzo Giglia. We are still awaiting approval from this committee. Palazzo Giglia project was also presented to the community and municipality. Being a historical palazzo, we have also applied for financing from the European Council

VICENZO CASTELLI [VC]_July 25, 2012_[Interviewer Natalia Woldarsky Meneses (N)]

$\mathrm{N}$ : In the acquisition of properties in Favara for the FARM project, was anyone displaced? Did you come across any issues with the nearby residents, municipality or others?

VC: The first two spaces built were the Moet champagneria and the Food shop, these spaces were empty but it took a long time to find the owners the spaces so that we could purchase them. Next to the Moet building, currently a gallery space, the space was lived in. We talked to them, asked if they wanted to a part of the project, they said no and they wanted a solution. See the space was not theirs, they were renting. We had to first find the owners and then asked the same question; they were also uninterested in the project and gave us a price. So we bought them out and the tenants went else to rent another unit. All the other spaces we have restored were empty.

$\mathrm{N}$ : Considering this situation, of some existing residents and then the incoming FKP group, how has this worked or not worked? Has it created a division in public and private spaces, or invisible thresholds? 
VC: The residents use the cortile, the kids play inside. They adopt it as theirs, it is open and public, it belongs to them. Yet the garden here, where we are, that FKP created is open to them, yet is a private space. They come and also don't come, because they understand it to be private. It's open but it's not your house, these social rules that are understood and respected. This whole cortile suffers from this contradiction. In fact all of Favara has these contradictions. The young people go to the sea, to San Leone, "un posto di minichia" (a fuck of a place), a totally different cultural space. And here was have FKP, a cultural park, but this space is not perceived for everyone, it depends on culture and education. What this place needs more PR but at the same time. FKP is not interested in filling the spaces with young people who do not appreciate it, they don't want to contaminate the space with young people who are not totally interested

This contradiction, see, unless an evening is organized, people do not come. Even then, it's an evening of contradictions. The administration and politics of the region do not understand the power of this project; they cannot see a long-term future. But it's the only project in the historical center that is working. The problem with many historical cities in Sicily is decay, they are disorganized, dirty and the government needs to control this, otherwise people abandon the historical center, then there are no services, water, garbage pick-up etc. The historical centre needs to be seen as a new way of living, it has to be thought through.

$\mathrm{N}$ : You told me last time that you traveled and worked outside of Favara, knowing these contradictions, why did you come back to Favara?

VC: I actually did not want to come back to this "territorio maledetto" (wretched/cursed place) but after all my European experiences, I wanted to bring something back to my place It's easy to leave and not come back, but it's harder to stay than to go. To deal with what you have, to try to make it better. That's why I stayed.

$\mathrm{N}$ : When you were young, did you come to this area?

VC: Yes, the buildings across from Maria's was where Antonio the electrician lived. My grandma lived nearby, I sued to come and play ball with Antonio. Oddly enough we found each other again years later working on this project. The best part of $7 \mathrm{C}$ is the cortile itself. It is the biggest social space. It has always been the public space, where people mix. It's the most natural space, there are no constraints or confusion regarding what is public and private space. Sure, the actual structure of the cortile aids in this activity, there are no exits, only one entrance, this gives in inner cortile a sense of privacy. There is a sense of closure, only one way to get in out, like a museum. You enter and exit from the same place and it gives the place a sense of security. There is control over who enters and exits, this is embedded in the structure of the spaces; it's its own security

$\mathrm{N}$ : What about the future of FARM, where do you see it going and what would you like to see?

VC: Everything done here was on a daily basis. That said, we never know what is next. Spaces come from inspired images, travels, in this way we find a synthesis for the project But they (Andrea and Florinda) have seen lots more than me, if I have seen $10 \%$ of the world, they have seen $50 \%$, so designing with them can be difficult at times. They control a lot of the design changes, l accept it since they do have some design/technical experience and so they have some informed knowledge when they make decisions or changes. But of course there are contradictions, I can see the space in a technical way, it should be comfortable, livable. And after finishing, we always see that there are also other solutions to making that space. Similar to design competitions, except nothing is ever final here. There are things I would like to change. I always tell Andrea and Florinda to make the spaces as flexible as possible, so that they can be more dynamic. At times we are in a state of contradiction, always working inside and not paying attention to the exterior. We do this because we know its best not to make too many holes or bring down too many walls when dealing with old building. You know, you risk having technical problems. We ail have different points of view. But I come from the school of thought were before I draw a line I have to know what I am dealing with, the social context, the urban one. My design process here has been high-jacked because we always have to work so quickly.

I am sure that after all the approvals when we start working, everything will change. For example, there are supposed to be 7 suites in the Palazzo Giglia project, and we know have to leave the exterior façade as is, but interior spaces can always change. And I know Andrea or Florinda can come in one and change it all.

N: How do you think your role will evolve as the project grows?

VC: This project (FARM) will not run on its own. I'll work here for another $10 \mathrm{yrs}$, and then I will go. But I think, that I don't need to be here or have a permanent job here, so long as the next architect knows what we are doing here. From there, everything is a domino effect. I don't wish to take the maternity or paternity of the project as the sole architect, I only wish to be responsible for the spaces, and for $7 \mathrm{C}$ as a whole since I brought Andrea here and encouraged him to make FARM here.

$7 \mathrm{C}$ was not the original space, it was older palazzo that we were looking at, the price was good, and the privacy of it. But then after Andrea saw $7 \mathrm{C}$ he changed his mind; in a certain 
way Andrea and Florinda think that if they can to "control" or trailor public space, a cultural shift can occur. They bought the spaces hoping that in the future it would be different and eventually they could move into some private residence here in 10-15 yrs. Owning much of the area also allows them to give their girls this opportunity

N: How do you see FARM, what does it mean to you?

VC: I see it as a project that is realistic, avant-guard that no one else can compare with, but unfortunately the problem is the territory, that is, the area is it in. There are so many social problems. The cultural and artistic messages cannot be heard from here. How to you make a doctor or lawyer understand the language of art. People have a distorted view of what architecture is, with the public you cannot do what you want, if you want to do something it has to be justified. With the public there is a different discourse. The public is one thing whereas the private is another. To design for the public means more, you need to be smart about it. The architect has to know the people and space they are working in, especially the urban condition, it's like reading a book, and you can't skip a page. The paradox in hiding what you are doing. I have been accused of this, since I do not have a website or wave my work to the public. I am private about my work and my colleges ask me why I don't have a website. The truth is I prefer to be on my own. I prefer to work on my own

MICHELE VITELLO [MV]_Member of Sicily Foundation_August 1, 2012 [Interviewer Natalia Woldarsky Meneses (N)]

$\mathrm{N}$ : How can you explain the desolate areas of Favara's city centre?

MV: After the economic boom of the 60 s people began to leave the historical centre and into the peripheries. Well let's go back a step and start with the discussion of the industria zones, everything begins from there. We have a history of more than 150 years of this; the Sicilian historical city centre is characterized by the displacement of people following the WWII. After the war came the depression, many social problems, lots of people left the historical city and Sicily overall, immigration abroad. From there, the major urban decay began and it got worse, until we had a major tragedy two years ago. You heard about the two children that were killed? There was a house that crumbled in the historical centre and it killed two girls, they were 4 and 13 years olds. I must say that from that point $7 \mathrm{C}$ was born. Of course Andrea was aiready thinking about this project but after that tragedy, is when the project really began. He was looking for a place for the project. But this crisis wasn't just about the death of the girls, I brought to light issues about the social decay and abandonment. There are people who want to see something else and this event brought about these voices. The problems that exist in the historical centre of Favara are common to many Sicilian towns. For example Agrigento, Grotta, Aragona, small towns of 5, 6, and 10000 people, all with empty spaces.

$\mathrm{N}$ : the government? How are the municipalities reacting to this, are there city plans? Some sort of regulation or project in place?

MV: Mmm, no, since the 1960 economic boom there was a lot of economic speculation, looking to building but nothing has come about. There is no intention or interest this sort of change in the city, to invest in the city

$\mathrm{N}$ : Speaking to Andrea and Enzo (Vicenzo Castelli), they also expressed this lack of interest from the city and stressed the originality of the FARM [FKP] project, how different it truly is. Specifically, this intention of wanting to give the city a new life

MV: All of this, this story, seems like a fairy tale; for us locals, for architects, for me, someone who has always been in love with the historical centre. What is happening is really incredible and unique and that few people in Favara are aware of

$\mathrm{N}$ : Earlier you mentioned that you are a lover of this area, of the historical centre. But tell me something, prior to FKP, what has happening in the historical centre, was there any action, could you come into this area? What was here?

MV: Well, I have always lived here. I bought his house 10 years ago. And everyone thought I was crazy. It was cheap, but I must tell you that 10 years ago I was lucky, it was cheaper, we were also still on the lira, I did benefit. But this typology of housing, this kind of space you cannot build anymore. Of course the major expense is restoring the space. It's a lot of work, it been 10 years since I have been working on this space. For example today in Favara you can buy within the historical centre at 10euro/square meter, sometimes up to 50euro/square meter, it is relatively low. Now there is even the phenonmena that houses are free 
N: Really? Daniele mentioned this to me, but I thought it was a figure of speech, really, free?

MV: Yes yes, Daniele was not joking. I even showed him a few places. He is still interested. I will explain how this came about. With Enzo [Vlcenzo Castelli]. have this group Sicily Foundation. We are volunteer architects. Our office was given to us. As a group, we look for spaces, that we can quote unquote give to people, that is, the services of restructuring/ renovating an old house to non-residents. Mostly to give them an incentive to come here and stay. This was how 1 explained this to Daniele

$\mathrm{N}$ : Ah, okay, I thought he was joking. I considered it was true to some extent, not totally free? I can understand you are trying to entice people into coming here and staying

M: Yes, you should even consider it (laughs) But let's be clear, what Andrea has done here is a miracle. And he is making others happen, for example Venice

N:Yes, I heard, I know he never expected it either (FKP was part of ltaly's Exhibit at the Venice Biennale 2012)

MV: But what we have to make clear to Favaresi is that Andrea cannot do everything. I never get tired of taking people to the historical centre. I propose affordable housing units that are free or 1000,2000 euro and that I will never tire of this because the objective make a group of this. Reach out to those who care enough to stay here and be a part of this change. But for all of this on one person, all on Andrea, it cannot be done. Even for the locals, they need to see this as an important project that is part of a network in which to involve them

$\mathrm{N}$ : Of course, it must be a network, if it is all on one person who do others get involved. It's not that Andrea will tire but what happens to the social network, it will not grow if it only one person.

MV: Of course a network is in place, one that began almost four years ago, before actual project was in place. Between myself and Enzo and a few others, finding the right place Andrea did not want to alone. He would tell us, fellas, don't leave me alone with this. The project of $7 \mathrm{C}$ was born many years ago. We would speak of a project that could give the historical centre some value, a second chance and using contemporary art as a means, but also including architecture, design, photography. And it's working. What we needed were new methods to attract attention to maintain what is here and also bring out new ideas. With Andrea we talked about this all the time that in 15 years there will be some much work to do. Not just in $7 \mathrm{C}$, but much more. The entire project that will revitalize the historical city is much larger, it is within another cortile that engulfs it. that is, the cortile of San Vito. Beginning in this piazza, San Vito, going down to Palazzo Micche, where the residence is, down to Palazzo Giglia and out via Zanaria. Its over 10,000 square meters in all. A whole piazza, many residences, like the house in front of us here, which I sold to a colleague, an architect who wants to be close to the FKP project

$\mathrm{N}$ So today, when you take a person to the historical centre, to show them possible houses they could buy, do they still think you are crazy?

MV: Absolutely not, (Laughs) thankfully not anymore. The extraordinary thing is this. After the second FKP project this summer, I met with a man who is trom Catania and he was interested in the FKP project, we chatting in a similar way I chatting with you now. And he wanted to know what was happening, what plans were, and asked to see some property. When we met he was with his whole family. I took him to see some lovely buildings, which I will show you tomorrow.

\section{$\mathrm{N}$ : (laughs) well, I can't move here just yef but that sounds great}

M: And so this man left in awe by the beautiful historical buildings in the city that no one visits and the size of them. So he wants to buy because he wants to have a place ready for when $3^{\text {td }}$ annual FKP party next June. This way he can be close to the project. This shows how the Andrea's project is really attracting people

$\mathrm{N}$ : Okay, yes that true. Can I ask you something though, perhaps this is a big question, possibility out of scope, but let imagine we are 10 years from now. There a more houses restored, more people who want to be close, but I wonder as a young person wanting to stay, where would I work? What industry, business could keep me here? Where could a person work in this city? Because you can have a city with a beautiful historical centre, give it a second life, restore the spaces, but how can you make a life? I know this is another issue

MV: yes, I know this is an issue, you are speaking of another thing. But listen, for example, my wife lives in Milano, my kids live in Milano. So I think I have already given you the answer. Sadly, we are still trying to find a way to be able to stay here, it really is difficult.

$\mathrm{N}$ : Of course, I can imagine. And it is a thing, what I hope it's okay with you when I say that it is very beautiful, that you chose to stay here. I spoke about this with Enzo, he told me 
the same thing; that it's hard to stay here, that it's easier to leave knowing what awaits you in this city. That you can leave and make your life elsewhere and that it be even easier for you. But that fact you guys stay is something else, it really amazes me. How it is connected to a place, so attached, it's incredible. And when I see this guys from NICODEMO. I am amazed by their work

MV: Yes, those guys are great; the work they do is amazing. And in the end it's usually the same 4 or 5 that do so much. It is a project born from this will and desire. My wish is to be able to take this out of the city, by this I mean, inviting architects and students from abroad and creating workshops. This way we can expand can gain more attention, but show the locals that these issues are larger than us, that there is interest and they can change. We have worked in the past with Calogero Gigila, do you know him? He is an architect here and had organized a few workshops with the faculty of architecture in Palermo and Agrigento. There is so much to do. You know after the tragedy of 2010 when those young girls died, the city began to demolish much of the city. These areas, white zones I call them, just sitting there empty, are reminders of the tragedy. We took one space over and made a garden, but there are so many more, it's quite sad to see these spaces in the city

$\mathrm{N}$ : Yes, I have seen them; they are sores in the city

MV: They are cemeteries. So the question is how to get people more involved. Its hard because some people even in Favara do not know what we are doing. There is more interest coming from outside the city and region.

$\mathrm{N}$ : Ah yes, but this is common in experimental projects of this kind. For example, years ago I lived in Arizona, the project called Arcosanti by an Italian architect. It has been there for 40 years now and yet the people nearby, the very neighbours of this project have no idea what it is. Yet for Soleri, this is his life's work, he has been there 40 years. He is able to attract people from so many other places. So many people arrive there from Japan, Italy. Colombia, Mexico. Canada and yet very few Americans know it is there.

MV: Well, yes this is incredible. And yet I am amazed of the work we have done here. If you had told me 10 years ago that this project would be here, that at the San Vito FARM residence Natalia from Canada would be here because she was interested in this city, I would have never believed you!

$\mathrm{N}$ : Yes and yet there are locals I met that have been to $7 \mathrm{C}$ or the historical city. When I was at the Antonella's birthday party the other day, I was chatting to with a woman. She was born and raised in Favara she told me she never came to the historical centre and had never been to $7 \mathrm{C}$. she has no idea FKP was even there. I was amazed. incredible. How do people not know? How can there be a whole area of city that people never go to?

MV:Yes, well, have you seen the photos of $7 \mathrm{C}$ before FKP arrived. All those spaces where empty, dirty, and only people that remained nearby where just waiting to die really. If you go to talk to Zia Maria today, she was born in $7 C$, she'll tell you another story

N: yes I know, I go see her every evening and we chat, but I never interrogate her this way. Sometimes she tells me of how it was before. She tells me that the old ladies in this area stay there and still come out in the evenings with their chairs and sit there. Even though they have to option of going to the new spaces, they still bring their chairs into the cortile. I think this is amazing. That the cortile continues to function as it did before.

MV: The cortile's roots are Arab, the whole area of $7 \mathrm{C}$ is Arab. But as a plan, more of the $16^{\text {th }}$ century. It is particular. The whole cortile is Bentivegna, with the $7 \mathrm{small}$ cortile inside. I think it is unique and singular within the city, it's quite particular. I know of something similar in Palermo. I know that city like my pocket, and historical city is fantastic

$\mathrm{N}$ : Tell me Michele, how did you meet Andrea or get involved in the FARM project

MV: Well, I have always worked for myself, in real estate you could say, selling and leasing spaces. I met Andrea through Enzo, they were looking for a place for the project. I don't technically work for Andrea, I consult with him as he does with me. Collaborating with him as well as with a larger architectural network in Agrigento and Palermo. Talking other architects, designers etc. and expanding not only FARM's network, but Favara's, that is how I am a part of this scene.

N: One last question, how exactly are you able to give houses for free as you say?

MV: Well, all of this again begins with the tragedy of 2010. After this event many places were targeted for demolition. Most of these places abandoned for years, finding the owners having left to other cities and so that have many owners, nephews, grandchildren, all of which then have ownership on the property. Most of them do not want the space. Our task 
is to find these owners, give them the option to sign the deed to us, this way ensuring that the place is not demolished and then we restore the space. This is how we are able to offer it to a new client at no charge.

$\mathrm{N}$ : so when a person takes a house like this

MV: the first this we do is to make sure the place is safe, structurally safe before renovating the interior. To ensure it does not crumble

$\mathrm{N}$ : okay, so if I take this house and you ensure it is safe to live in, then restore it, how do you live? How do you make a living?

MV: (laughs) my wife who lives in Milan pays...no but seriously though. The cost of restoring a space does come from the client, meaning what they must pay the contractor. Here you can restore a space at approximately 350 euro/square meter. Sure that is a low cost, but here is where a person has to pay this to a contractor

$\mathrm{N}$ : of course, it's still money, but you could not find this is another cities

MV: what we do for the client is the working drawings, permitting and setting up the project to make it liveable with our volunteer architects.

N: wow, well that's something l've never heard. That's another Favara miracle. Great.

NADIA CASTRONOVO [NC] \& CARMELO NICOTRA [CN]_Members of Associazione Culturale NiCODERM [ND]_August 10,2012

[interviewer: Natalia Woldarsky Meneses (N)]

Natalia : When and how did the group form?

NC: The group was formed by Rino, Samantha and Analisa in 2009, at that time these guys had come back to Favara after finishing their studies and realized that there was nothing to do in this town, gatherings began at home, among friends and then there was talking of making it into a formal group instead of whining about the fact that there was nothing to do here. Carmelo was the first member to join, I joined 6 months later.

$\mathrm{N}$ : What are the intentions of the group, when it formed and are these still being fulfilled today?

NC: Yes, it's even more than anyone expected; speaking in regards to the activities than ND involves itself in; though apolitical as a group, recently we have become involved with groups that have a clear political and religious stand point. It is important that we are apolitical, in a certain way it maintains a peace among us

$\mathrm{N}$ : What relationships have been formed with other groups or organizations with ND?

NC: We began to have a rapport with the city, we began just before FARM, and having the same intentions we went to meet Andrea Bartoli at the grand opening. he liked us and wanted to work with us. (Aside: Analisa Argo is president of ND and also of the "congunto giovanile" in Favara and is connected to all youth/community groups in Favara, this helped ND). We collaborate with other groups in the city, but generally speaking ND does much more (activities and events) than other groups in the city. Other groups we work with or have worked with; MelaBlue, Favarbria Donna, BeniComuni, BeddaFavara

CN: As for FKP; we went to introduced ourselves to them at the grand opening in June 30, 2010, by July of that year we were screening $1 / 2$ of our film series at FKP and brought all kinds of people to the $7 \mathrm{C}$ (the other $1 / 2$ were screened at the monastery) We are always looking for ways to bring people to spaces that are not well known in the city, such as the monastery

$\mathrm{N}$ : What does ND do, as community events?

$\mathrm{CN}$ : We host the film series in the summer, in the fall there is a theatre group, we also sponsor musical events, we once did a musical series called "Seeker concert"; an idea we 
borrowed which involves showcasing small indie bands via online videos and a small tour, we called our initiative "Losco" (comes from the word "nascoto" meaning hidden). Our events are always available to the public via a small entrance fee. such as with the film series, we also publish a free press monthly and it is also found online called "InFolio"

N:What were you doing before NO?

NC- I have always been interested in art. photography, music and cultural events, before ND I would pursue these type of events in other places. I would catch a bus to Palermo or Agrigento for these things

$\mathrm{CN}$ - I too was always involved in art, having studied fine arts in Palermo. I was there up until last year, but much of work connects to the cultural and historical spaces of Favara my thesis was also on Favara.

$\mathrm{N}$ :Were you born in Favara? And prior to the FARM project, did you ever visit $7 \mathrm{C}$, why or why not?

$\mathrm{CN}$ - I was born in Agrigento, literally next door, but raised in Favara. I did go to the historical centre and to $7 \mathrm{C}$ prior to FARM. My artwork has always revolved around the history, culture and traditions trapped within the historical center of this city. My work has always had this anthropological perspective; there were spaces I would go and observe. photograph and event paint. It is an area that is slowly being lost, it has been forgotten and the traditions embedded within it are being lost, those that can only be found here in the city. It makes me sad, and I try to find ways to bring them back.

$\mathrm{N}$ : When you would visit $7 \mathrm{C}$, would you go alone, or with friends? Did they think you were nuts because nobody really went there

NC: I would go alone, other times with friends but only with those who shared similar interests in the culture and history of the historical center. It's absurd that this part of the city has been abandoned. FARM has been the first to bring something to this area, it something we were all waiting for, it has a full-on invasive intervention.

N-Regarding the cultural, anthropological and historical traditions within $7 \mathrm{C}$, do you think the FKP's project will in anyway maintain these?

CN: FKP's language is contemporary and international, it has helped put Favara on the map, but it's a different project. They have showcased some artists that are deeply rooted in the Favara's history such as Clement. What the artwork FKP shows, well, it could be anywhere else.

NC: the first year at FKP, it was always busy, there were DJs and aperitivos all the time; people would go there before going out, people would even come from Agrigento, something that was unheard of. Today FKP is growing outside Sicily, on an international scale, its being exported in a certain way this year, its projecting itself outside and there are less activities here. One great event last year was "Enjoy Contemporary Sicily" where several artists, curators, filmmakers, architects, dancers; all sorts of artists came that summer, all kinds of networks were created; young kids came from all over Sicily to meet and chat with them, they even offered portfolio meetings, it was a great event.

$\mathrm{N}$ : Would you say that the events that FKP hosts appeal to a specific group of people within the city?

CN: FKP is important because it has reclaimed the historical centre and it should be applauded for this. The problem is there are events every 3 to 4 months, there are other times of the year when it seems closed, some people just do not understand

NC: Before FKP began I didn't go the 7C, after the first buildings in Favara began to crumble there was an up rage in the city; many buildings were scheduled for demolition. A that time I went to see $7 \mathrm{C}$. l'd like to see a more organized program, something more stable and constant, it's not Andrea's fault that people don't go, the Favaresi are not into art in this way. We are an anomaly here. When the ORTUS project was being designed by architect Giacomo Sorce, many community youth groups were invited to be a part of this social reclaim project, but they all refused to join in; this continues to surprise me. We went, we jump at any opportunity. But FKP's cortile has nothing to with Favara or the culture; there is a break, a break in culture

$\mathrm{N}$ : And even within this break/gap between the project and the city, is it still a good project for Favara?

NC: Yes, the people who live there have access to things they didn't have before. Sure, inside there is confusion between public and private spaces; they have invaded a space without working with the people who have always lived there. What they need is a specialized person to develop the social aspects of 7C, FKP needs to be more social, it is a guest at $7 \mathrm{C}$. 


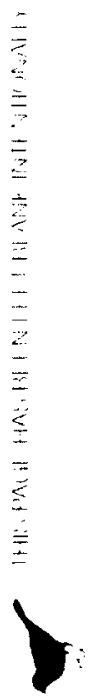




\section{b i b l i o g r a p h y}

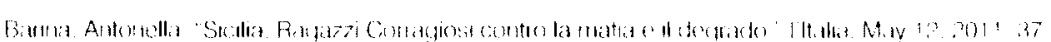

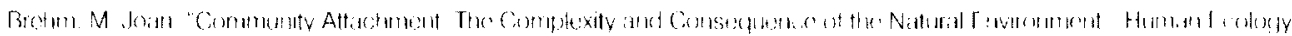

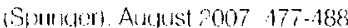

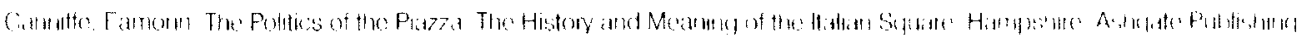
tirutert 2008

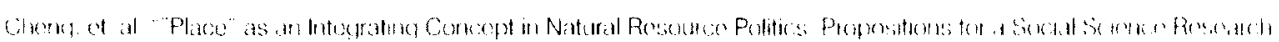

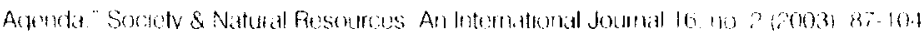

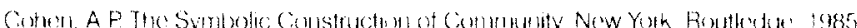

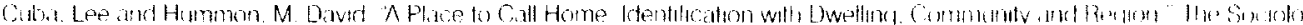

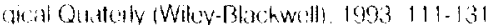

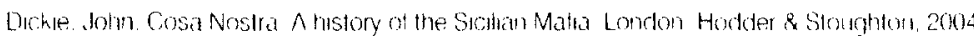

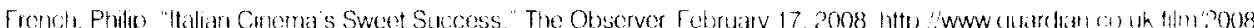

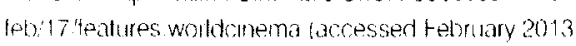

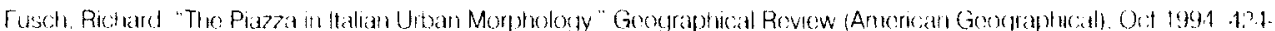
438

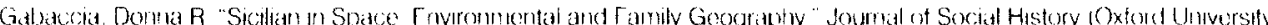
Press) 16, no 2 (Winter 198? 53.66

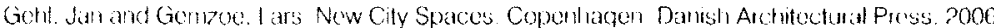

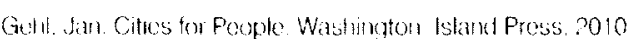

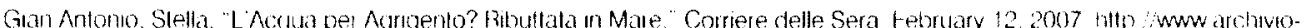

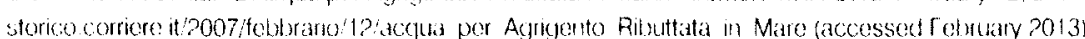

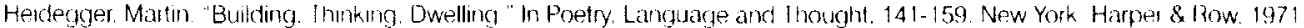

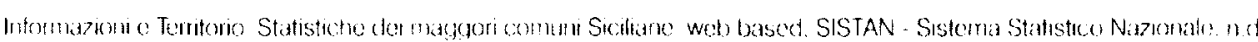

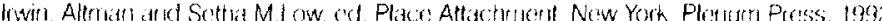

Warobs, thine. The Lite and Death of Great American Citres New York Vintage Books. 190 


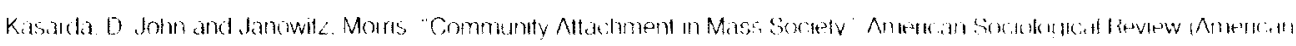

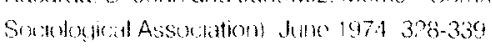

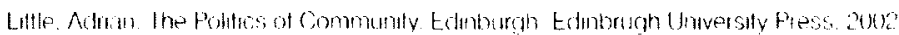

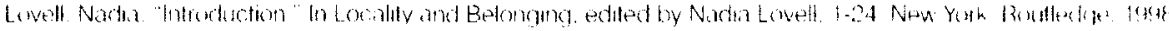

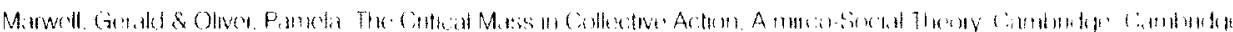

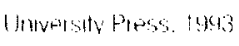

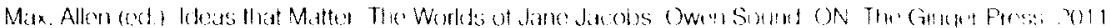

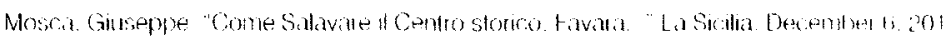

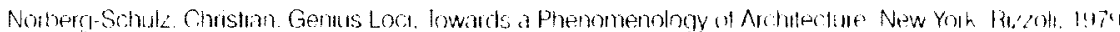

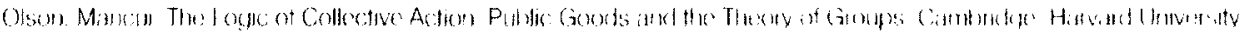
Plowis 1965

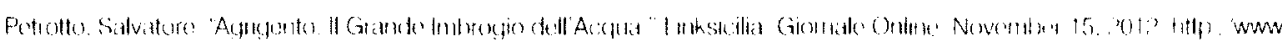

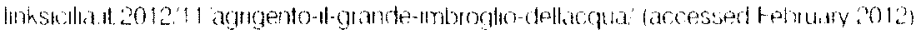

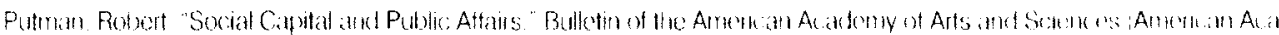
(temv ot Nots and Scrences) 47. no. 8 (May 19941 5. 19

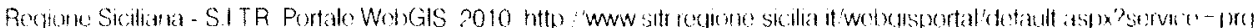
arcessed 112012

Relpti. T. Place and Placelessness I nidon Pion I imted. 1976

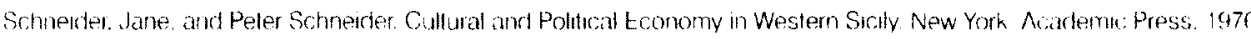

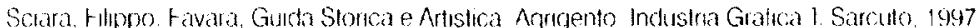

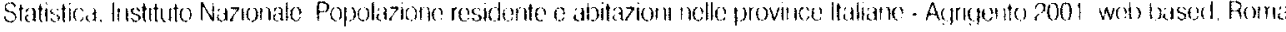
Institutio Nacionale Statislica, 2006

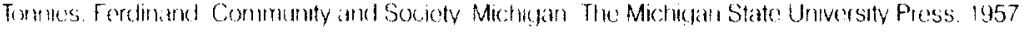

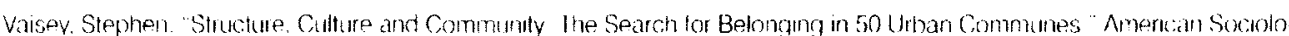
gical Review (American Sociologicial Assockation). December ?007 851 1.873

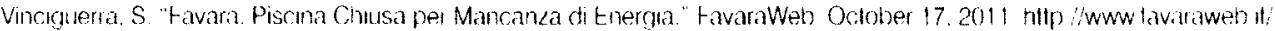
news:"p- 14989 (accessod relotualy 2013$)$

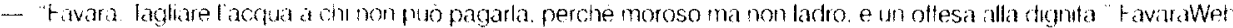

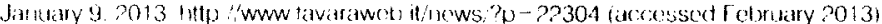

